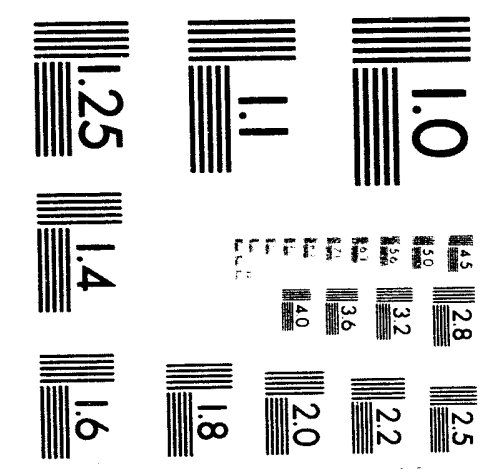



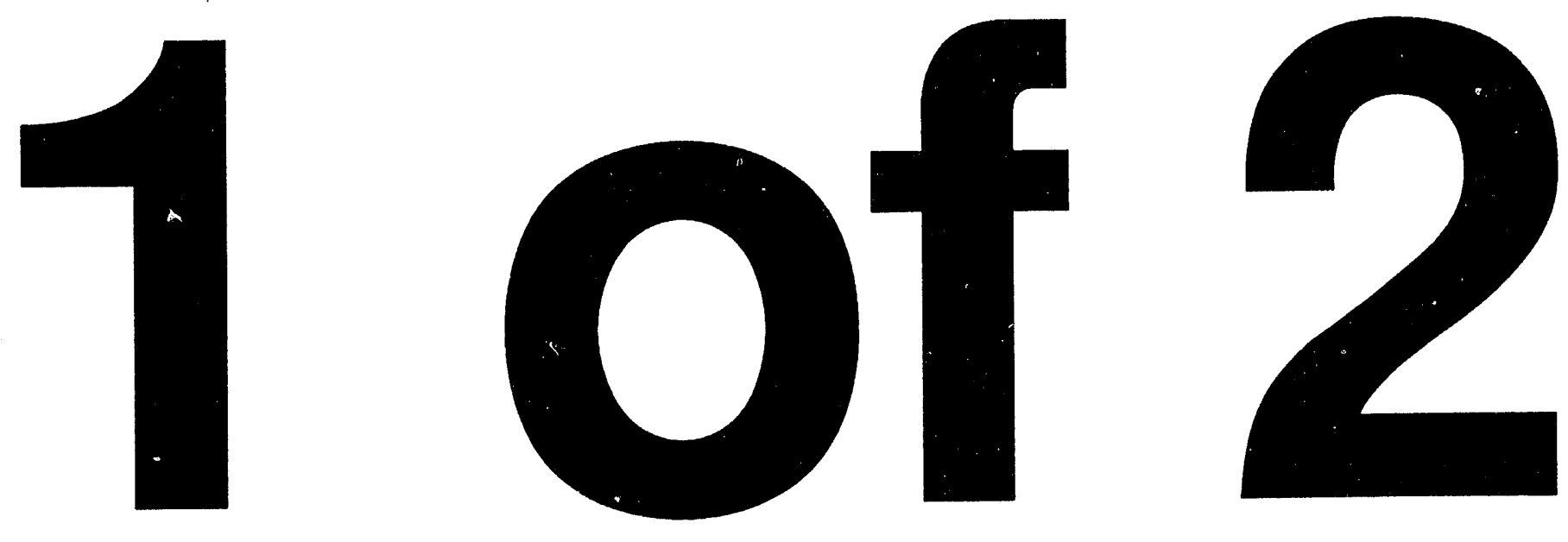


\title{
Annual Report-1992 Environmental Surveillance for EG\&G Idaho Waste Management Facilities at the Idaho National Engineering Laboratory
}

\author{
Roger N. Wilhelmsen \\ Kelly C. Wright \\ Dennis W McBride
}

Published August 1993

\author{
Idaho National Engineering Laboratory \\ EG\&G Idaho, Inc. \\ Idaho Falls, Idaho 83415
}

Prepared for the

U.S. Department of Energy

Assistant Secretary for Environmental

Restoration and Waste Management

Under DOE Idaho Operations Office

Contract DE-AC07-76ID01570

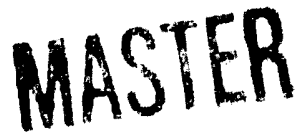




\begin{abstract}
This report describes the 1992 environmental surveillance activities of the Environmental Monitoring Unit of EG\&G Idaho, Inc., at EG\&G Idaho-operated Waste Management facilities at the Idaho National Engineering Laboratory (INEL). The major facilities monitored include the Radioactive Waste Management Complex, the Waste Experimental Reduction Facility, the Mixed Waste Storage Facility, and two surplus facilities. Included are some results of the sampling performed by the Radiological and Environmental Sciences Laboratory and the United States Geological Survey. The primary purposes of monitoring are to evaluate environmental conditions, to provide and interpret data, to ensure compliance with applicable regulations or standards, and to ensure protection of human health and the environment. This report compares 1992 environmental surveillance data with DOE derived concentration guides, and with data from previous years.
\end{abstract}

\title{
DISCLAIMER
}

This report was prepared as an account of work sponsored by an agency of the United States Government. Neither the United States Government nor any agency thereof, nor any of their employees, makes any warranty, express or implied, or assumes any legal liability or responsibility for the accuracy, completeness, or usefulness of any information, apparatus, product, or process disclosed, or represents that its use would not infringe privately owned rights. Reference herein to any specific commercial product, process, or service by trade name, trademark, manufacturer, or otherwise does not necessarily constitute or imply its endorsement, recommendation, or favoring by the United States Government or any agency thereof. The views and opinions of authors exp? ssed herein do not necessarily state or reflect those of the United States Government or any agency thereof. 


\section{SUMMARY}

This report describes the 1992 Radiological Environmental Surveillance Program (RESP) activities of the Environmental Monitoring (EM) Unit of EG\&G Idaho, Inc., at EG\&G Idahooperated Waste Management facilities at the Department of Energy (DOE), Idaho National Engineering Laboratory (INEL). Results are presented for the 1992 air, water, soil, biotic, and ambient radiation monitoring activities performed at the Radioactive Waste Management Complex (RWMC), the Waste Experimental Reduction Facility (WERF), the Mixed Waste Storage Facility (MWSF), and the two contaminated surplus facilities which are the Stationary Low-Power Reactor No. 1 (SL-1) and the Organic-Moderated Reactor Experiment (OMRE). In addition, this report discusses current methods and monitoring programs of the RESP along with subsurface water monitoring at the RWMC by the United States Geological Survey (USGS).

All gross beta activities of airbome particulate material measured in 1992 at the RWMC, WERF, and MWSF were below DOE derived concentration guides (DCGs) for airborne release to a public area. Gamma spectrometric analyses did not identify any gamma-emitting radionuclides above background in airborne particulates at the RWMC, WERF, or MWSF.

There were no statistically significant differences between gross beta concentrations of airborne particulates measured at the RWMC and those measured at the control location, and the concentrations were consistent with historical values. No gamma-emitting radionuclides resulting from operational activities were detected at levels above background in airbome particulates at the RWMC. All air samples collected during 1992 were also submitted for alpha - and betacmitting radionuclide analysis. Low-level concentrations of Am-241 were detected in the first and third quarters of the year; and low-level concentrations of Pu-239,-240 were detected in the second quarter. The concentrations for these radionuclides were $0.05 \%$ and $0.03 \%$ of their DCGs respectively for airborne releases to the public. No airbome releases of alpha- and betaemitting radionuclides were detected during the fourth quarter.

No gamma-emitting radionuclides, that could be attributed to operational activities, were detected in any of the RWMC surface water runoff samples collected in 1992. Results indicated that radionuclide concentrations in surface water transported via run-off water from contaminated surfaces at the RWMC were not greater than historical concentrations or DCGs and were at or near background le vels.

Soil samples were collected at the SWEPP area. No gamma-cmitting radionuclides that can be attributed to Waste Management operations were detected. Selected soil samples were also submitted for specific alpha-and beta-emitting radionuclide analysis. Due to circumstances beyond the control of the analytical laboratory, this data was not available in time for inclusion into this report. This data will be reviewed upon receipt and evaluated for inclusion in the 1993 annual report.

In the routine vegetation samples (Russian thistle) collected at the RWMC, no gammaemitting radionuclides were detected in any of the samples. Selected vegetation samples were also submitted for specific alpha- and beta-emitling radionuclide analysis. These samples contained detectable concentrations of $\mathrm{Sr}-90$ and Am-241 that exceed the levels found in the control sample. However, these concentrations were below concentrations of previous years and were also within the range of results reported by RESL.

During 1992, ground squirrels and excavated soil samples were scheduled for collection. However, the recontouring efforts at the RWMC has brought about a diminishing population of 
ground squirrels. As a result, no samples were collected for either media.

Around the current waste disposal pit and at localized areas within the SDA, thernnoluminescent dosimeter (TLD) data showed exposures above background exposures; however, in the vicinity of the disposal pit, exposures have decreased in recent years due to additional soil cover. Surface radiation surveys showed radiation levels above background levels. The maximum six-month ionizing radiation exposure measured by TLDs at the RWMC have, in general, decreased over time since 1974. Analysis of the WERF TLD data from November 1982 to November 1992 shows that the six-month exposures measured immediately around the WERF waste storage area were higher than all other exposures measured at WERF. This difference is due to the proximity of the TLD monitoring location to the radioactive waste storage area at WERF.

Surface radiation was routinely monitored at RWMC, and at both surplus facilities SL-1 and OMRE. No areas at the RWMC showed a reading of greater than $1 \mathrm{mR} / \mathrm{h}$ at $0.9 \mathrm{~m}(3 \mathrm{ft})$. No areas with levels exceeding the SL-1 administrative control limit $(20 \mathrm{mR} / \mathrm{h}$ gamma at contact with the soil surface) were identified at SL-1. No areas at the OMRE exceeded the administrative contrul limit (1 mR/h at contact).

The USGS wells at the RWMC are monitored regularly for selected volatile organic compounds, specific conductance, chloride, and sodium. No maximum contaminant levels were exceeded for volatile organic compound and radiological analyses. No positive detections of gamma-emitting radionuclides were detected in any of the wells.

Tritium was detected in three of nine RWMC wells monitored by the USGS with a maximum concentration of $(1.5 \pm 0.2) \mathrm{E}-6 \mu \mathrm{Ci} / \mathrm{mL}$, which is $0.08 \%$ of the appropriate DCG. The source of this tritium is attributed to past disposals from waste water operations at the Idaho Chemical Processing Plant and the Test Reactor Area. The concentrations detected in 1992 were similar to results reported in previous years. 


\section{ACKNOWLEDGMENTS}

The authors wish to thank all of the people who contributed to the preparation of this report: Steve Peterson and Matt Hankins for assistance in sample collection and preparation and Larry Blackwood for his contributions to the statistical sections of this report; the Radiation Measurements Laboratory and the Bioassay Group, especially Don Koeppen, Cal Rowsell, and Caroline Filby, for providing analyses and results; the Radiological and Environmental Sciences Laboratory, especially Diana Hoff, for providing data on airborne particulates and penetrating radiation; the United States Geological Survey, especially Brennon Orr, for providing the data on subsurface water monitoring; Ralph Clark for editing this report; Electronic Publications-Site for formatting and proofing the document. 


\section{CONTENTS}

ABSTRACT $\ldots \ldots \ldots \ldots \ldots \ldots \ldots \ldots \ldots \ldots \ldots \ldots \ldots \ldots \ldots \ldots \ldots \ldots \ldots \ldots \ldots \ldots \ldots \ldots$

SUMMARY $\ldots \ldots \ldots \ldots \ldots \ldots \ldots \ldots \ldots \ldots \ldots \ldots \ldots \ldots \ldots \ldots \ldots \ldots$

ACKNOWLEDGMENTS $\ldots \ldots \ldots \ldots \ldots \ldots \ldots \ldots \ldots \ldots \ldots \ldots \ldots \ldots \ldots$ vii

ACRONYMS AND ABBREVIATIONS $\ldots \ldots \ldots \ldots \ldots \ldots \ldots \ldots \ldots \ldots \ldots \ldots \ldots \ldots$

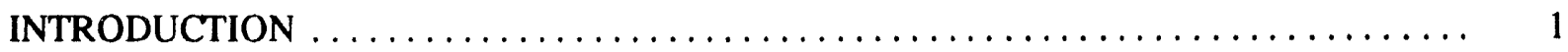

Overview of Monitoring Activities $\ldots \ldots \ldots \ldots \ldots \ldots \ldots \ldots \ldots \ldots \ldots \ldots \ldots \ldots \ldots \ldots \ldots \ldots$

Radiological Environmental Surveillance of Waste Management Facilities ....... 2

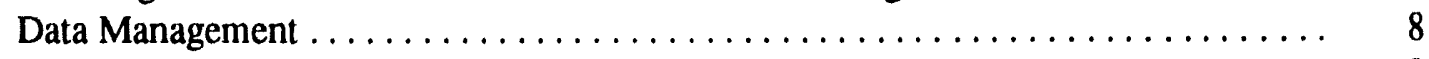

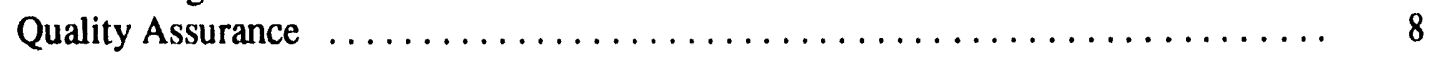

Description of Waste Management Facilities $\ldots \ldots \ldots \ldots \ldots \ldots \ldots \ldots \ldots \ldots \ldots$

Radioactive Waste Managment Complex ...................... 8

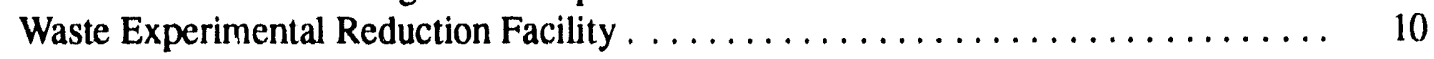

Stationary Low-Power No. 1 Surplus Area $\ldots \ldots \ldots \ldots \ldots \ldots \ldots \ldots \ldots \ldots \ldots \ldots$

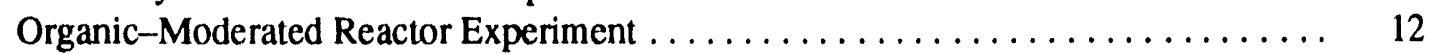

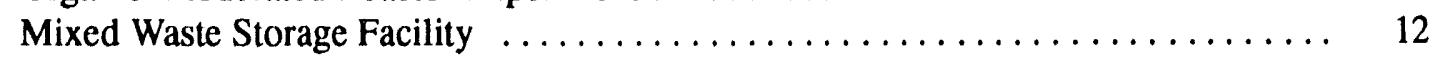

MONITORING METHODS AND RESULTS $\ldots \ldots \ldots \ldots \ldots \ldots \ldots \ldots \ldots \ldots \ldots$

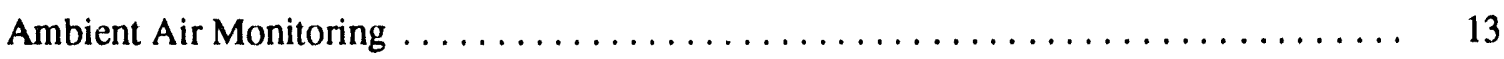

Radioactive Waste Management Complex $\ldots \ldots \ldots \ldots \ldots \ldots \ldots \ldots \ldots \ldots \ldots$

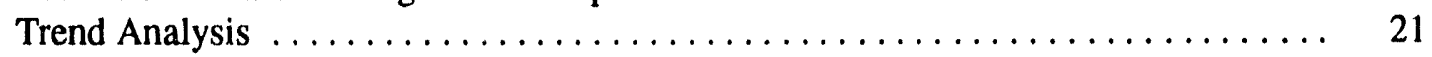

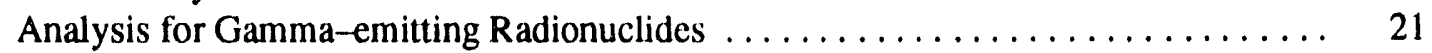

Analysis for Specific Alpha- and Beta-Emitting Radionuclides $\ldots . \ldots \ldots \ldots \ldots . \ldots 21$

Waste Experimental Reduction Facility . . . . . . . . . . . . . . . . . 25

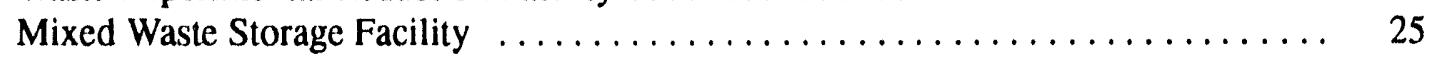

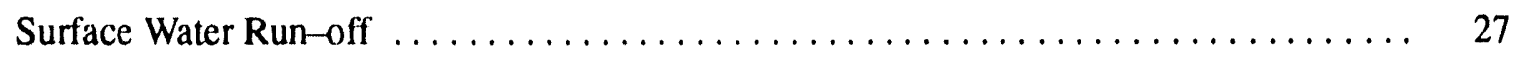

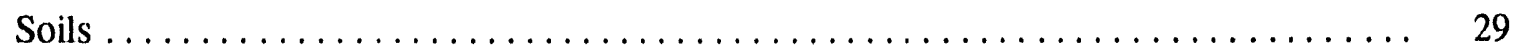

Radioactive Waste Management Complex .................... 29

Waste Experimental Reduction Facility . . . . . . . . . . . . . . . . 32

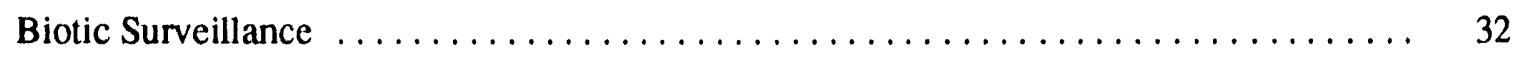

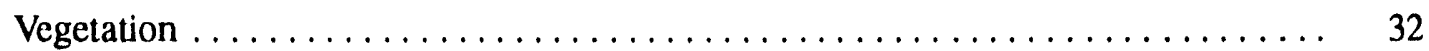

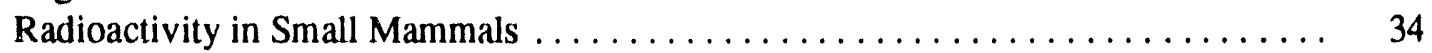

Soil Excavated by Small Mammals $\ldots \ldots \ldots \ldots \ldots \ldots \ldots \ldots \ldots \ldots \ldots \ldots \ldots$

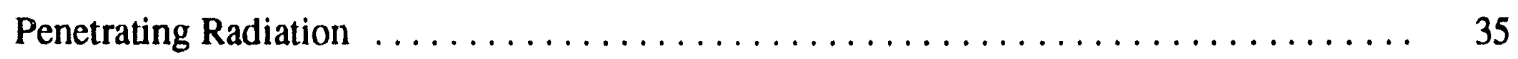


Radioactive Waste Management Complex .................... 35

Waste Experimental Reduction Facility $\ldots \ldots \ldots \ldots \ldots \ldots \ldots \ldots \ldots \ldots \ldots \ldots$

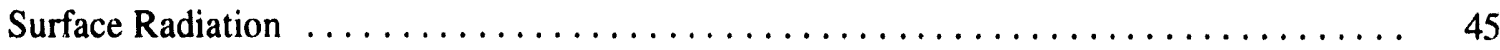

Radioactive Waste Management Complex ...................... 45

Stationary Low-Power Reactor No. $1 \ldots \ldots \ldots \ldots \ldots \ldots \ldots \ldots \ldots \ldots \ldots \ldots \ldots$

Organic-Moderated Reactor Experiment $\ldots \ldots \ldots \ldots \ldots \ldots \ldots \ldots \ldots \ldots \ldots$

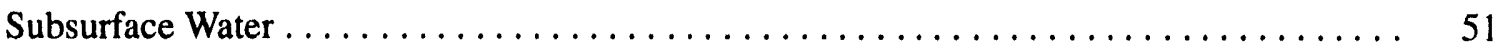

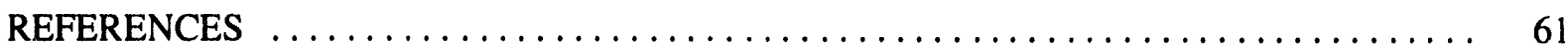

Appendix A-Quality Assurance $\ldots \ldots \ldots \ldots \ldots \ldots \ldots \ldots \ldots \ldots \ldots \ldots \ldots \ldots \ldots \ldots \ldots$

Appendix B-Detection Limits $\ldots \ldots \ldots \ldots \ldots \ldots \ldots \ldots \ldots \ldots \ldots \ldots \ldots \ldots \ldots \ldots \ldots \ldots$

Appendix $\mathrm{C}-$ Statistical Methods $\ldots \ldots \ldots \ldots \ldots \ldots \ldots \ldots \ldots \ldots \ldots \ldots \ldots \ldots \ldots \ldots \ldots$

Appendix D-Environmental Standards $\ldots \ldots \ldots \ldots \ldots \ldots \ldots \ldots \ldots \ldots \ldots \ldots \ldots \ldots \ldots \ldots \ldots$

\section{FIGURES}

1. Idaho National Engineering Laboratory location $\operatorname{map} \ldots \ldots \ldots \ldots \ldots \ldots \ldots$

2. Map of the Radioactive Waste Management Complex $\ldots \ldots \ldots \ldots \ldots \ldots \ldots \ldots \ldots$

3. Aerial photograph of the Radioactive Waste Management Complex (facing west) ...... 9

4. Aerial photograph of the Stored Waste Examination Pilot Plant (facing south) $\ldots \ldots \ldots$ II

5. Aerial photograph of the Waste Experimental Reduction Facility (facing east) $\ldots \ldots \ldots$ 11

6. Collection of particulate air filter from $L V$ air sampler $\ldots \ldots \ldots \ldots \ldots \ldots \ldots \ldots \ldots$

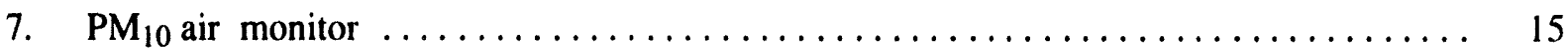

8. RWMC TSP air monitoring locations prior to July $2,1992 \ldots \ldots \ldots \ldots \ldots \ldots \ldots \ldots$

9. RWMC TSP and $\mathrm{PM}_{10}$ air monitor locations after July $2,1992 \ldots \ldots \ldots \ldots \ldots$

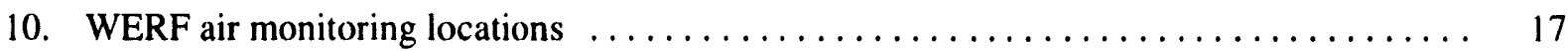

11. WERF air monitoring control location $\ldots \ldots \ldots \ldots \ldots \ldots \ldots \ldots \ldots \ldots \ldots \ldots \ldots$

12. RESL's air sampling network at the INEL and vicinity $\ldots \ldots \ldots \ldots \ldots \ldots \ldots \ldots \ldots$

13. Quarterly averages of RWMC gross beta air concentrations since $1979 \ldots \ldots \ldots \ldots \ldots$

14. Maximum gross beta concentrations (Cs-137 equivalent) for SDA air filters

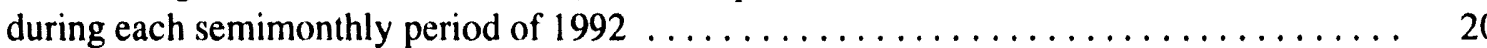


15. Maximum gross beta concentrations (Cs-137 equivalent) for SWEPP air filters during each semimonthly period of 1992

16. 1992 gross alpha concentrations for TSP air monitors using fifth order polynomial smoothing

17. 1992 gross alpha concentrations for $\mathrm{PM}_{10}$ air monitors using third order polynomial smoothing

18. 1992 gross beta concentrations for TSP air monitors using fifth order

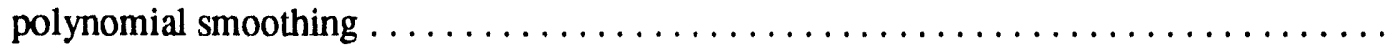

19. 1992 gross beta concentrations for $\mathrm{PM}_{10}$ air monitors using third order

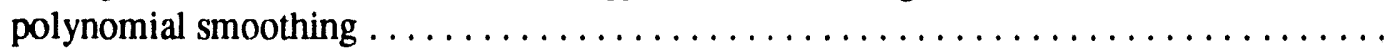

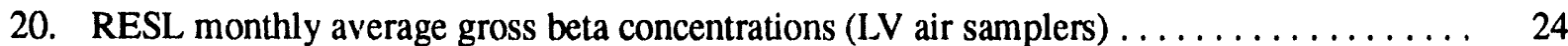

21. Am-241 and Pu-239,-240 quarterly composite concentrations for air filters at RWMC locations. The derived concentration guide per DOE Order 5400.5 for $\mathrm{Am}-241$ and $\mathrm{Pu}-239,-240$ is $2.0 \times 10^{-14} \mathrm{mCi} / \mathrm{mL}$

22. Quarterly average of gross beta air concentrations measured at WERF

23. Maximum gross beta concentrations (Cs-137 equivalent) for WERF air filters during each semimonthly period of 1992

24. Maximum gross beta concentrations (Cs-137 equivalent) for SWEPP air filters during each semimonthly period of 1992

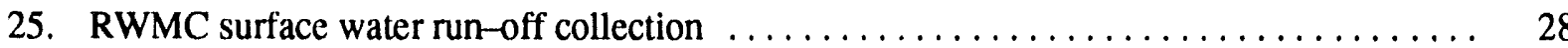

26. Sampling locations for surface water run-off $\ldots \ldots \ldots \ldots \ldots \ldots \ldots \ldots \ldots \ldots \ldots$

27. Soil sample collection $\ldots \ldots \ldots \ldots \ldots \ldots \ldots \ldots \ldots \ldots \ldots \ldots \ldots \ldots \ldots \ldots \ldots \ldots$

28. Five major areas of the RWMC used for vegetation, mammal, and soil collection ...... 30

29. General SWEPP soil locations $\ldots \ldots \ldots \ldots \ldots \ldots \ldots \ldots \ldots \ldots \ldots \ldots \ldots \ldots \ldots$

30. WERF TLD soil and vegetation locations $\ldots \ldots \ldots \ldots \ldots \ldots \ldots \ldots \ldots \ldots \ldots \ldots$

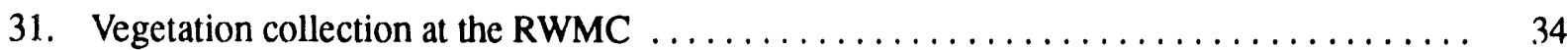

32. Placement of a TLD at a facility perimeter station $\ldots \ldots \ldots \ldots \ldots \ldots \ldots \ldots \ldots \ldots$

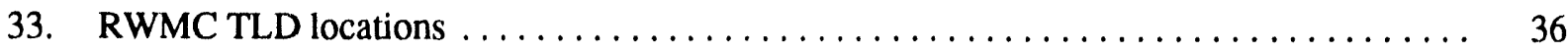

34. Six-month exposures measured by TLDs on the west end of the north border

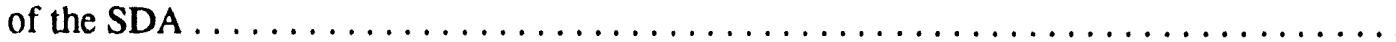

35. Six-month exposures measured by TLDs on the east end of the north border of the SDA 
36. Six -month exposures measured by TLDs on the south border of the SDA $\ldots \ldots \ldots$

37. Six-month exposures measured by TLDs on the southwest border of the SDA $\ldots \ldots \ldots 38$

38. Six-month exposures measured by TLDs on the southeast border of the SDA . . . . . . 39

39. Six-month exposures measured by TLDs on the west border of the SDA . . . . . . . . 39

40. Six-month exposures measured by two of the four TLDs on the east border

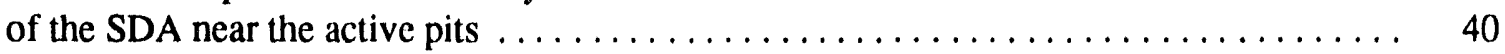

41. Six-month exposures measured by two of the four TLDs on the east border

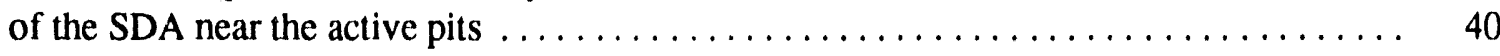

42. Exposure trends for the spring and fall average TLD measurements $\ldots \ldots \ldots \ldots \ldots$

43. Six-month exposures measured by TLDs on the north border of the TSA $\ldots \ldots \ldots 43$

44. Six-month exposures measured by two of the four TLDs on the south and southeast borders of the TSA

45. Six-month exposures measured by TLDs on the south border of the TSA

46. Six-month exposures measured by TLDs on the east and northeast borders of the TSA

47. Six-month exposures measured by TLDs north of TSA

48. Six-month exposures measured by TLDs located $500 \mathrm{~m}$ and $400 \mathrm{~m}$ northeast of WERF

49. Six-month exposures measured by TLDs located $300 \mathrm{~m}$ and $200 \mathrm{~m}$ northeast of WERF

50. Six-month exposures measured by TLDs located northeast and southeast of the 50-m perimeter around WERF

51. Six-month exposures measured by TLDs located southwest and northwest of the 50-m perimeter around WERF

52. Six-month exposures measured by TLDs at 440-m perimeter around WERF

53. Pinpointing areas of increased radiation levels using the VRM-1 and HHD -440 meter radiation detector system

54. Results of 1992 spring and fall RWMC surface radiation surveys $\ldots \ldots \ldots \ldots \ldots \ldots$

55. OMRE surface gamma radiation survey area and areas exceeding background levels $\ldots \ldots \quad 52$

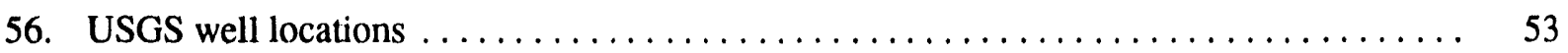

57. Tritium concentrations in RWMC wells $\ldots \ldots \ldots \ldots \ldots \ldots \ldots \ldots \ldots \ldots \ldots \ldots \ldots \ldots \ldots \ldots \ldots \ldots$ 


\section{TABLES}

1. Environmental Monitoring activities performed at Waste Management facilities ...... 3

2. Results of chemical analyses of subsurface water at the RWMC in $1992 \ldots \ldots \ldots \ldots$

3. Concentrations $(\mathrm{mg} / \mathrm{L}$ or $\mathrm{ppb})$ of selected volatile organic compounds in groundwater ... 56

4. Results of radiochemical analyses of RWMC subsurface water $\ldots \ldots \ldots \ldots \ldots \ldots \ldots$ 


\section{ACRONYMS AND ABBREVIATIONS}

\begin{tabular}{|c|c|c|c|}
\hline Am & americium & ETR & Engineering Test Reactor \\
\hline ARA & Auxiliary Reactor Area & EWR & $\begin{array}{l}\text { Early Waste Retrieval (RWMC pro- } \\
\text { gram) }\end{array}$ \\
\hline ATR & Advanced Test Reactor & & \\
\hline$A G$ & Bioassay Group & $\mathrm{H}-3$ & tritium \\
\hline$C \& S$ & Certified and Segregated Waste & HEPA & high-efficiency particulate air \\
\hline & Storage & HV & high-volume \\
\hline CFA & Central Facilities Area & IDAPA & $\begin{array}{l}\text { Idaho Administration Procedures } \\
\text { Act }\end{array}$ \\
\hline CFR & Code of Federal Regulations & & \\
\hline $\mathrm{Cl}$ & chloride & IET & Initial Engine Test \\
\hline Co & cobalt & ILTSF & $\begin{array}{l}\text { Intermediate-Level Transuranic } \\
\text { Storage Facility }\end{array}$ \\
\hline $\begin{array}{l}\text { Cs } \\
\text { CTF }\end{array}$ & $\begin{array}{l}\text { cesium } \\
\text { Containment Test Facility }\end{array}$ & INEL & $\begin{array}{l}\text { Idaho National Engineering Labor- } \\
\text { atory }\end{array}$ \\
\hline $\mathrm{CV}$ & coefficient of variation & LLW & low-level radioactive waste \\
\hline DCG & derived concentration guide & LV & low-volume \\
\hline DOE & U.S. Department of Energy & MAR & monitoring activity review \\
\hline DOE-ID & $\begin{array}{l}\text { U.S. Department of Energy Idaho } \\
\text { Operations Office }\end{array}$ & $\begin{array}{l}\text { MCL } \\
\text { MTR }\end{array}$ & $\begin{array}{l}\text { maximum contaminant level } \\
\text { Materials Test Reactor }\end{array}$ \\
\hline DQO & data quality objectives & MWSF & Mixed Waste Storage Facility \\
\hline DVS & Drum Vent System & $\mathrm{Na}$ & sodium \\
\hline EBR-I & Experimental Breeder Reactor No. 1 & NRTS & National Reactor Testing Station \\
\hline ECG & $\begin{array}{l}\text { Environmental Concentration } \\
\text { Guidelines }\end{array}$ & OMRE & $\begin{array}{l}\text { Organic-Moderated Reactor Experi- } \\
\text { ment }\end{array}$ \\
\hline EDE & effective dose equivalent & PBF & Power Burst Facility \\
\hline EG\&G & EG\&G Idaho, Inc. & $\mathrm{PM}_{10}$ & particulate matter $\leq 10 \mu$ \\
\hline EM & Environmental Monitoring (Unit) & $\mathrm{Pu}$ & plutonium \\
\hline ESP & $\begin{array}{l}\text { Environmental Surveillance Pro- } \\
\text { gram Data Management System }\end{array}$ & QA & quality assurance \\
\hline
\end{tabular}




\begin{tabular}{|c|c|c|c|}
\hline $\mathbf{R a}$ & radium & TCA & 1,1,1-tetrachloroethane \\
\hline RESL & $\begin{array}{l}\text { Radiological and Environmental } \\
\text { Sciences Laboratory }\end{array}$ & $\begin{array}{l}\text { TCE } \\
\text { TLD }\end{array}$ & $\begin{array}{l}\text { trichloroethylene } \\
\text { thermoluminescent dosimeter }\end{array}$ \\
\hline RESP & $\begin{array}{l}\text { Radiological Environmental Sur- } \\
\text { veillance Program }\end{array}$ & TRA & Test Reactor Area \\
\hline RML & Radiation Measurements Laboratory & TRU & transuranic \\
\hline RWMC & Radioactive Waste Management & TSA & Transuranic Storage Area \\
\hline & Complex & TSF & Technical Support Facility \\
\hline $\mathrm{Sb}$ & antimony & TSP & total suspended particulate \\
\hline SDA & Subsurface Disposal Area & $\mathrm{U}$ & uranium \\
\hline SL-1 & $\begin{array}{l}\text { Stationary Low-Power Reactor } \\
\text { No. } 1\end{array}$ & $\begin{array}{l}\text { USGS } \\
\text { VOC }\end{array}$ & $\begin{array}{l}\text { United States Geological Survey } \\
\text { volatile organic compound }\end{array}$ \\
\hline SPERT & $\begin{array}{l}\text { Special Power Excursion Reactor } \\
\text { Test }\end{array}$ & VRM-1 & $\begin{array}{l}\text { vehicle-mounted roadway moni- } \\
\text { tor-1 }\end{array}$ \\
\hline $\mathrm{Sr}$ & strontium & WERF & $\begin{array}{l}\text { Waste Experimental Reduction } \mathrm{Fa} \text { - } \\
\text { cility }\end{array}$ \\
\hline SWEPP & $\begin{array}{l}\text { Stored Waste Examination Pilot } \\
\text { Plant }\end{array}$ & WIPP & Waste Isolation Pilot Plant \\
\hline TAN & Test Area North & WRRTF & Water Reactor Research Test Facility \\
\hline
\end{tabular}




\section{Annual Report-1992 Environmental Surveillance for EG\&G Idaho Waste Management Facilities at the Idaho National Engineering Laboratory INTRODUCTION}

In 1949, the National Reactor Testing Station (NRTS) was established in southeastern Idaho by the U.S. Atomic Energy Commission as an area to build, test, and operate nuclear reactors, a fuelprocessing plant, and support facilities with maximum safety and isolation. In 1974, the NRTS was redesignated as the Idaho National Engineering Laboratory (INEL) to reflect a broader scope of engineering and scientific activities. The INEL is owned by the Department of Energy (DOE), and EG\&G Idaho, Inc. is the prime contractor.

The INEL covers a $2300-\mathrm{km}^{2}\left(890-\mathrm{mi}^{2}\right)$ area in southeast Idaho. The region is characterized as a cool desert. During the summer, days are warm and nights are cool; in winter, days and nights are cold and dry. Annual average precipitation is $22 \mathrm{~cm}$ (8.7 in.), with maximum levels occurring in winter and late spring. The annual average temperature is $5.6^{\circ} \mathrm{C}\left(42^{\circ} \mathrm{F}\right)$, with recorded extremes of -44 and $39^{\circ} \mathrm{C}\left(-47\right.$ and $\left.103^{\circ} \mathrm{F}\right) .^{\prime}$ During the summer months, a pronounced diurnal reversal in wind direction occurs; winds blowing from the southwest (up slope) predominate during daylight hours, and northeasterly (down slope) winds persist at night. The reversal normally occurs a few hours after sunrise and again shortly after sunset.

Subsurface geology at the INEL consists of successive layers of basalt and sedimentary strata, overlaid at the surface by wind-and water-deposited sediments. The primary groundwater feature of the region is the Snake River Plain aquifer underlying the INEL. Surface waters include the Big Lost River, the Little Lost River, and Birch Creek. They originate in the mountain areas to the north and west and infiltrate the ground within the INEL area. Both aquifer and surface waters are used for irrigation of crops outside the INEL. Aquifer water is used as a drinking water source both on and off the INEL.

The flora in areas surrounding the Waste Management areas of EG\&G Idaho are typical of those found elsewhere on the INEL. ${ }^{2}$ Vegetation consists principally of sagebrush, perennial herbs, and grasses. Reptiles, birds, and both small and large mammals are abundant. ${ }^{3,4}$ Game species such as sage grouse and antelope are frequently seen in these areas.

The Radiological Environmental Surveillance Program (RESP) provides monitoring data for all EG\&G Idaho Waste Management facilities. The DOE Radiological and Environmental Sciences Laboratory (RESL) performs routine monitoring outside the Radioactive Waste Management Complex (RWMC) and around other operational facilities on the INEL site, as well as at the INEL boundaries and at distant locations off of the INEL. The RESP activities are structured to support the DOE Idaho Operations Office (DOE-ID) in maintaining an integrated INEL environmental monitoring program. The National Oceanic and Atmospheric Administration cooperates with RESL on a meteorology monitoring network.

The RESP, conducted by the Environmental Monitoring (EM) Unit, has the following general objectives: (a) provide indications of confinement integrity at EG\&G Idaho radioactive waste storage and disposal facilities, (b) ensure compliance with applicable requirements regarding environmental surveillance of radioactivity at DOE Waste Management facilities, (c) identify trends in concentrations of radioactivity in environmental media near EG\&G Idaho Waste Man- 
agement facilities, (d) make monitoring data available to other programs conducting activities such as performance assessment, pathways analysis, and dose estimation, and (e) collect data in support of special studies designed to enhance RESP technical capabilities.

These stated program objectives are to be interpreted as including the program objectives identified in DOE Order 5400.1, Chapter IV and DOE Order 5820.2A, Chapter II for environmental surveillance of DOE Waste Management facilities. ${ }^{5,6}$

The EM Unit currently is responsible for radiological environmental surveillance and compliance monitoring (including drinking water monitoring and nonradiological liquid-effluent monitoring). The EM Unit also conducts nonroutine sampling in support of specific EG\&G Idaho programs and landlord operations.

In previous years, Environmental Monitoring's annual report included RESP, drinking water, and nonradiological liquid effluent monitoring programs. In 1991, each program began preparing a program specific annual report.

The scope of this report only includes the activities of RESP.

\section{Overview of Monitoring Activities}

\section{Radlological Environmental Survelllance of Waste Management Facilities}

A comprehensive radiological monitoring program is conducted at EG\&G Idaho Waste Management facilities. This program includes routine and special studies of radioactive materials in air, water, soil, and biota (vegetation and small mammals), and monitoring of ambient radiation (see Table 1 ).

The Waste Management facilities monitored by EM at the INEL (see Figure 1) include: the
RWMC, the Waste Experimental Reduction Facility (WERF), the Stored Waste Examination Pilot Plant (SWEPP), the Mixed Waste Storage Facility (MWSF), the Stationary Low-Power Reactor No. 1 (SL-1) surplus area, and the Organic-Moderated Reactor Experiment (OMRE) area.

The RWMC is used to dispose of low-level radioactive waste (LLW) and to store transuranic (TRU) waste received from other DOE Sites. Other Waste Management activities conducted at the WERF, MWSF, and SWEPP, include waste reduction; incineration; and storage of mixed waste, TRU waste certification and processing, research, and technology development.

Airborne transport is the most likely near-term pathway for radionuclide migration from the active RWMC and WERF facilities. Consequently, more extensive air monitoring is conducted at these facilities to detect airborne transport of radionuclides.

Surface water run-oli sampling is conducted quarterly at the RWMC if sufficient water is available. These samples are analyzed to determine radionuclide concentrations in run-off water and to determine if radionuclide transport from the area is possible during run-off conditions. Generally, run-off water does not flow from the RWMC except during or after heavy rainfalls or snowmelt.

The INEL Project Office of the United States Geological Survey (USGS) monitors groundwater in the Snake River Plain aquifer, which is approximately $177 \mathrm{~m}(580 \mathrm{ft})$ beneath the RWMC. This monitoring helps determine whether radionuclides and hazardous constituents have migrated from the waste to the groundwater. Water samples are collected quarterly from eight aquifer wells and one perched-water well located in and adjacent to the RWMC Subsurface Disposal Area (SDA). These samples are analyzed for radiological as well as nonradiological parameters. 
Table 1. Environmental Monitoring activities performed at Waste Management facilities.

\begin{tabular}{|c|c|c|c|c|}
\hline Facility & $\begin{array}{c}\text { Sample } \\
\text { Type/Measurement }\end{array}$ & Description & Frequency of Analysis & Type of Analysis \\
\hline \multicolumn{5}{|l|}{ RWMC } \\
\hline \multirow{7}{*}{ SDA } & - $\mathrm{PM}_{10}{ }^{\mathrm{a}}$ & $\begin{array}{l}8 \text { air monitors operated at } 0.11 \mathrm{~m}^{3} / \mathrm{min} \\
\text { (includes } 1 \text { control and } 1 \text { replicate) }\end{array}$ & $\begin{array}{l}\text { Semimonthly } \\
\text { Semimonthly } \\
\text { Monthly } \\
\text { Quarterly }\end{array}$ & $\begin{array}{l}\text { Gross alpha } \\
\text { Gross beta } \\
\text { Gamma spectrometry } \\
\text { Radiochemistry }\end{array}$ \\
\hline & $\begin{array}{l}\text { - Total suspended } \\
\text { particulate }\end{array}$ & 1 air monitor operated at $0.14 \mathrm{~m}^{3} / \mathrm{min}$ & $\begin{array}{l}\text { Semimonthly } \\
\text { Semimonthly } \\
\text { Monthly } \\
\text { Quarterly }\end{array}$ & $\begin{array}{l}\text { Gross alpha } \\
\text { Gíoss úêtá } \\
\text { Gamma spectrometry } \\
\text { Radiochemistrya }\end{array}$ \\
\hline & Surface Water & One 4-L sample from SDA and control location & $\begin{array}{l}\text { Quarterly, but depends } \\
\text { on precipitation }\end{array}$ & $\begin{array}{l}\text { Gross alpha } \\
\text { Gross beta } \\
\text { Gamma spectrometry } \\
\text { Radiochemistryb,c,d }\end{array}$ \\
\hline & Direct Radiation & & & \\
\hline & - Surface gamma activity & Truck-mounted VRM-1 detector system & Semiannually & External radiation levels \\
\hline & $\begin{array}{l}\text { - Ionizing Radiation } \\
\text { (conducted by RESL } \\
\text { and EG\&G Idaho) }\end{array}$ & $\begin{array}{l}25 \text { TLD packets (RESL), } 2 \text { TLD packets (EG\&G } \\
\text { Idaho) and } 7 \text { background communities (RESL) }\end{array}$ & Semiannually & $\begin{array}{l}\text { External radiation } \\
\text { levels }\end{array}$ \\
\hline & Small Mammal & $\begin{array}{l}3 \text { composites in each of } 5 \text { major areas (plus } 1 \text { control } \\
\text { area) }\end{array}$ & $\begin{array}{l}\text { Annually, but species } \\
\text { sampled varies each year } \\
\text { depending on availability }\end{array}$ & $\begin{array}{l}\text { Gamma spectrometry } \\
\text { Radiochemistryb }\end{array}$ \\
\hline
\end{tabular}


Table 1. (continued).

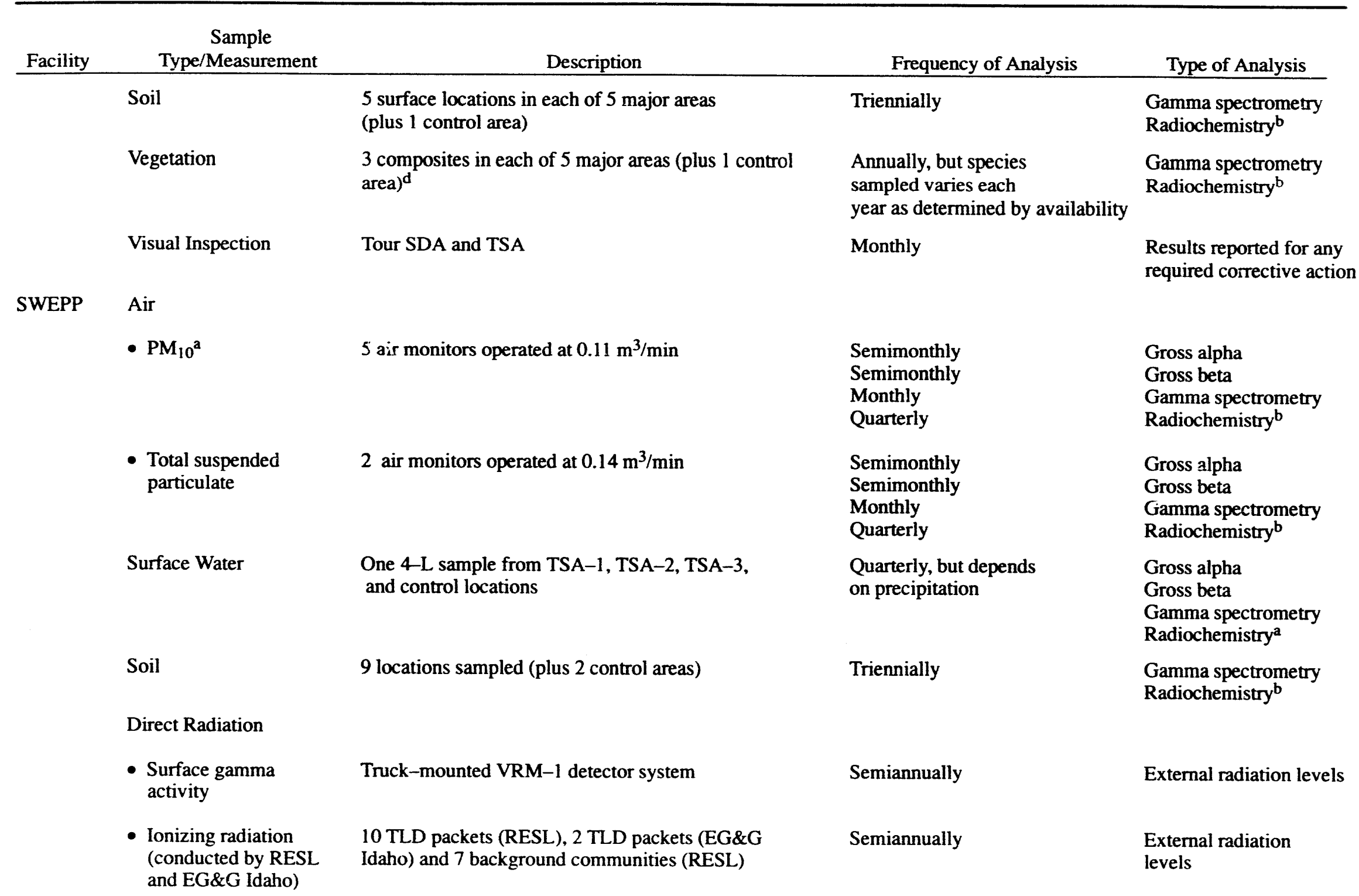


Table 1. (continued).

\begin{tabular}{|c|c|c|c|c|}
\hline \multirow[t]{4}{*}{ WERF } & Air & & & \\
\hline & - $\mathrm{PM}_{10} \mathrm{a}^{\mathrm{a}}$ & $\begin{array}{l}4 \text { air monitors operated at } 0.11 \mathrm{~m}^{3} / \mathrm{min} \\
\text { (includes } 1 \text { control and } 1 \text { replicate) }\end{array}$ & $\begin{array}{l}\text { Semimonthly } \\
\text { Semimonthly } \\
\text { Monthly }\end{array}$ & $\begin{array}{l}\text { Gross alpha } \\
\text { Gross beta } \\
\text { Gamma spectrometry }\end{array}$ \\
\hline & Direct Radiation & & & \\
\hline & $\begin{array}{l}\text { Ionizing radiation } \\
\text { conducted by RESL } \\
\text { and EG\&G Idaho }\end{array}$ & $\begin{array}{l}11 \text { TLD packets (EG\&G Idaho) and } 7 \text { background } \\
\text { communities (RESL) }\end{array}$ & Semiannually & $\begin{array}{l}\text { External radiation } \\
\text { levels }\end{array}$ \\
\hline \multirow[t]{2}{*}{ MWSF } & Air & & & \\
\hline & - $\mathrm{PM}_{10}{ }^{\mathrm{a}}$ & 1 air monitor operated at $0.11 \mathrm{~m}^{3} / \mathrm{min}$ & $\begin{array}{l}\text { Semimonthly } \\
\text { Semimonthly } \\
\text { Monthly }\end{array}$ & $\begin{array}{l}\text { Gross alpha } \\
\text { Gross beta } \\
\text { Gamma spectrometry }\end{array}$ \\
\hline \multirow[t]{3}{*}{ SL-1 } & Direct Radiation & & & \\
\hline & $\begin{array}{l}\text { - Surface gamma } \\
\text { activity }\end{array}$ & Hand-held HHD- 440 & Semiannually & $\begin{array}{l}\text { External radiation } \\
\text { levels }\end{array}$ \\
\hline & Visual Inspection & Tour SL-1 & Semiannually & $\begin{array}{l}\text { Results reported for any } \\
\text { required corrective action }\end{array}$ \\
\hline
\end{tabular}


Table 1. (continued).

\begin{tabular}{|c|c|c|c|c|}
\hline \multirow[t]{3}{*}{ OMRE } & Direct Radiation & & & \\
\hline & $\begin{array}{l}\text { - Surface gamma } \\
\text { activity }\end{array}$ & Truck-mounted VRM-1 detector system & Annually & External radiation levels \\
\hline & Visual Inspection & Tour OMRE & Annually & $\begin{array}{l}\text { Results reported for any } \\
\text { required corrective action }\end{array}$ \\
\hline \multicolumn{5}{|c|}{ a. $\quad \mathrm{PM}_{10}$ air monitoring started in July 1992.} \\
\hline \multicolumn{5}{|c|}{ b. Analysis for Am-241, Pu-238, Pu-239,-240, U-235, U-238, and Sr-90. } \\
\hline \multicolumn{5}{|c|}{ c. Samples for radiochemical analyses usually taken during second quarter only. } \\
\hline \multicolumn{5}{|c|}{ d. Exact number of samples may vary, due to availability. } \\
\hline \multicolumn{5}{|c|}{ e. Sampling frequency may vary if air radioactivity levels increase. } \\
\hline
\end{tabular}




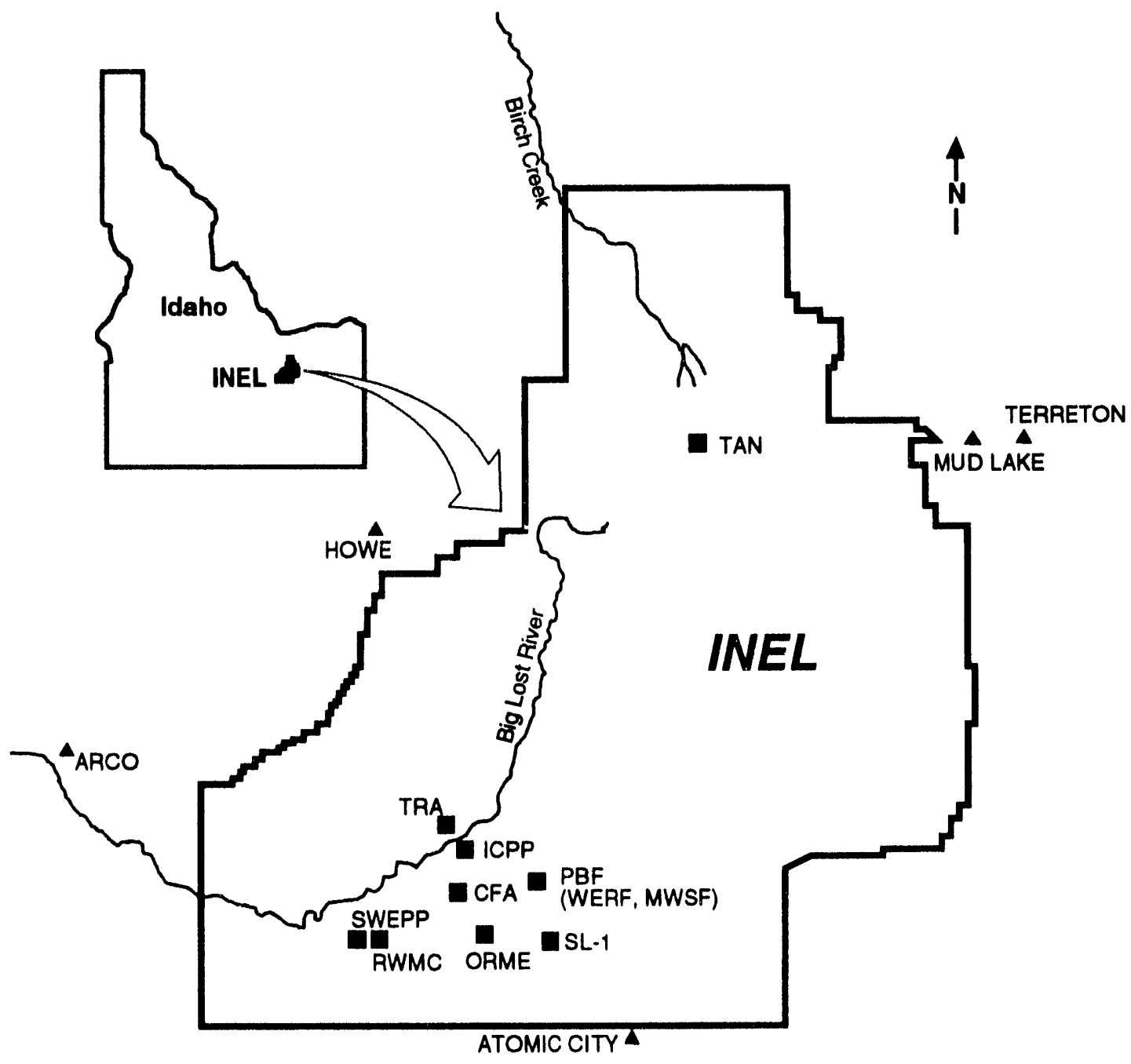

Selected Facilities at the Idaho National Engineering Laboratory

$\begin{array}{ll}\text { CFA } & \text { Central Facilties Area } \\ \text { ICPP } & \text { Idaho Chemical Processing Plant } \\ \text { MWSF } & \text { Mixed Waste Storage Facility } \\ \text { OMRE } & \begin{array}{l}\text { Organic Moderated Reactor } \\ \text { Experiment (inactive) }\end{array} \\ \text { PBF } & \text { Power Burst Facility }\end{array}$

RWMC Radioactive WasteManagement Complex

SL-1 Stationary Low Power Reactor No.1 Burial Ground

SWEPP Stored Waste Examination Pilot Plant

TAN Test Area North

TRA Test Reactors Area

WERF Waste Experimental Reduction Facility
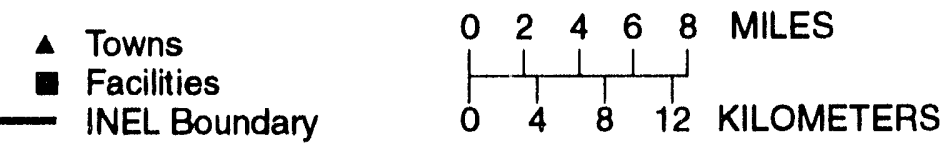

V92 0013

Figure 1. Idaho National Engineering Laboratory location map. 
The RESP is responsible for routine soil surveillance at the WERF and RWMC. A preliminary assessment of surface soils was conducted at all EG\&G Idaho facilities during 1989 and periodic soil monitoring outside the WERF and RWMC is conducted by RESL. The purposes of soil sampling and analyses are to determine if RWMC and WERF operations contribute to soil contamination, and to determine long-term trends. Surface soils at the RWMC demonstrate radionuclide levels slightly above background due to past transportation and handling of radioactive wastes, from past flooding, ${ }^{7}$ and/or by migration from buried waste. Surface soils at WERF could possibly become contaminated by deposition of radionuclides in airborne effluents or as a result of radioactive waste handling.

Biota can affect the integrity of buried contaminated waste by penetrating the soil and allowing water to reach the waste, or by transporting radionuclides to the surface. Therefore, routine sampling of small mammals and vegetation is also conducted by EM to detect potential biological radionuclide transport. Vegetation sampling is conducted at the WERF and RWMC. Small mammal sampling and sampling of soil excavated by burrowing animals are conducted only at the RWMC.

Thermoluminescent dosimeters (TLDs) are used to measure cumulative exposures to ambient ionizing radiation at the RWMC and WERF. The TLDs are used to detect increases in antbient exposures attributable to handling, processing, or disposal of radioactive waste. In addition, a surface radiation survey is conducted at the RWMC every six months to monitor all areas within the facility boundary.

The SL-1 surplus area, located near the SL-1 reactor site, contains buried contaminated building remnants in one pit and two trenches. The OMRE area includes a leach pond and an area formerly occupied by a reactor facility, which has been decontaminated and decommissioned. Both SL-1 and OMRE are nonoperational surplus facilities and require less surveillance than the RWMC, WERF, and
MWSF. Table 1 summarizes the monitoring activities conducted at the RWMC, MWSF, WERF, SL-1, and OMRE during 1992.

\section{Data Management}

The Environmental Surveillance Program Data Management System (ESPDMS) has beer. developed for radiological monitoring activities at EG\&G Idaho Waste Management facilities. The purposes of the ESPDMS are to maintain databases (air, water, soil, biota, and TLD), store and sort data, provide a method of tracking trends in monitoring data, and help generate various monitoring reports.

\section{Quality Assurance}

The Quality Assurance (QA) Program is integrated into all of the measurement programs described above. The QA Program has been developed both to ensure the representativeness of sampling methods and to verify the quality of reported results. Sampling and analysis protocols have been documented in detailed procedures for the collection, analysis, and reporting of results. A description of the QA Program is found in the Quality Program Plan for Environmental Monitoring. ${ }^{8}$ Detailed QA information on the RESP such as data quality objectives and quality assurance objectives can be found in the RESP Program Plan. (See Appendix A for quality assurance objectives.)

\section{Description of Waste Management Facilities}

\section{Radioactive Waste Management Complex}

The RWMC occuinies 62 ha (154 acres) of the southwestern part of the INEL (see Figures 2 and 3 ), in the north-central portion of the eastern Snake River Plain. The facility is situated in a small valley surrounded by basaltic ridges rising to $18 \mathrm{~m}(60 \mathrm{ft})$ above the landscape. Surface sediments vary in thickness from 0 to $7 \mathrm{~m}(0$ to $23 \mathrm{ft}$ ) and consist of unconsolidated clay, silt, and gravel. The elevation is $1527 \mathrm{~m}(5010 \mathrm{ft})$ above mean sea level. 


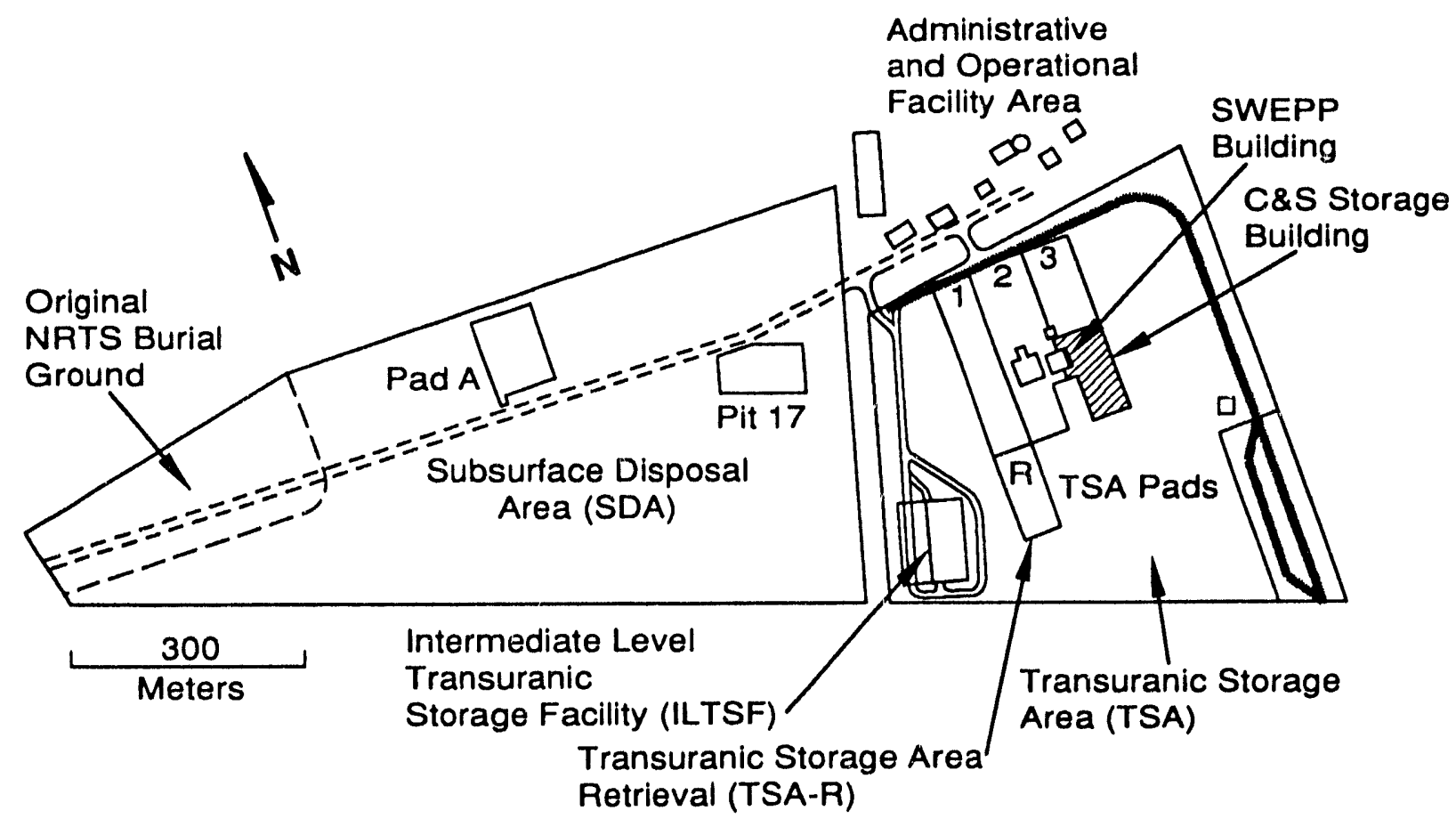

Figure 2. Map of the Radioactive Waste Management Complex.

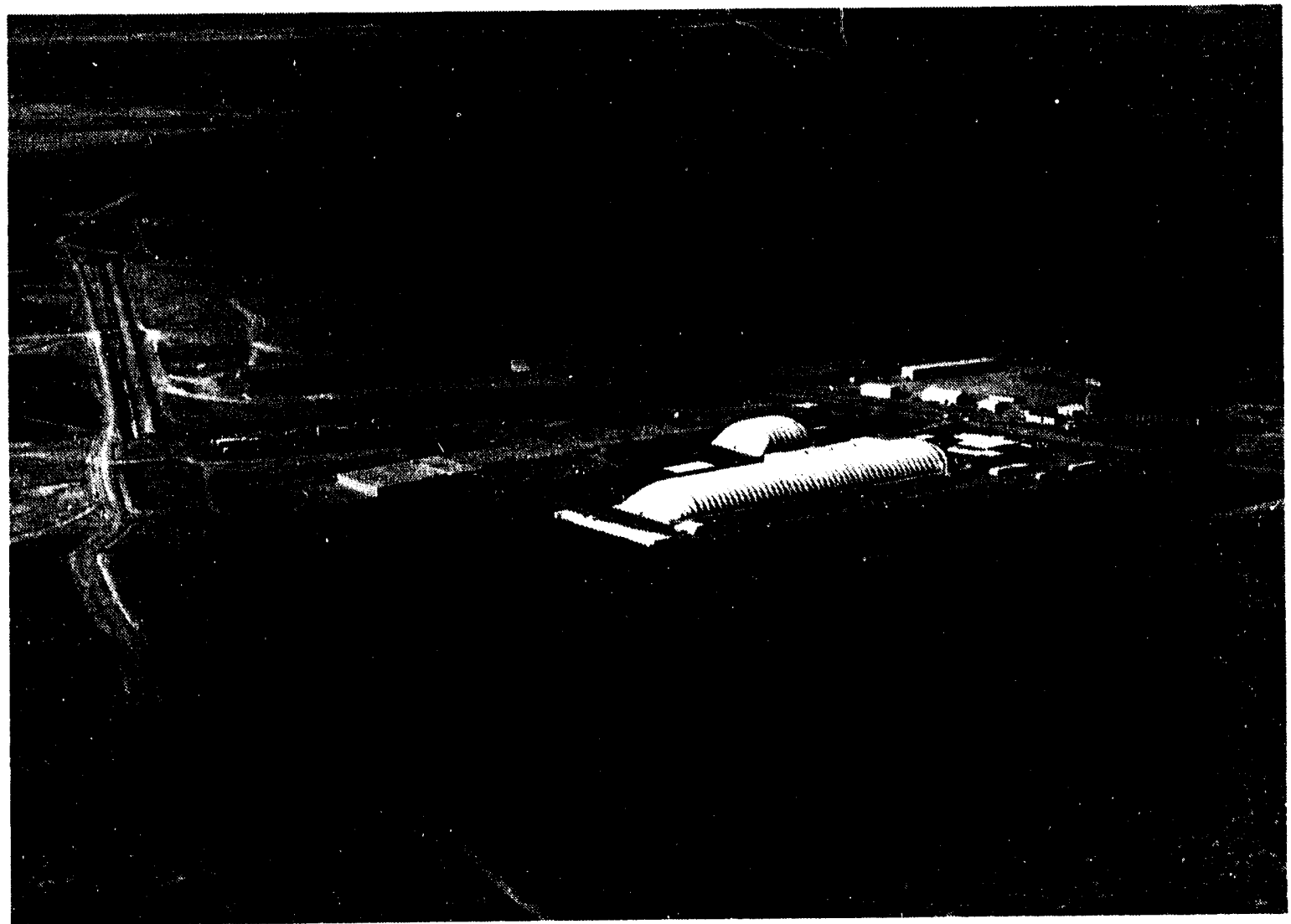

Figure 3. Aerial photograph of the Radioactive Waste Management Complex (facing west). 
Three major areas are within the RWMC: the SDA, 36 ha (88 acres); the Transuranic Storage Area (TSA), 22 ha (56 acres); and the Administrative and Operational Facility area, 4 ha (10 acres). Low-level waste is segregated at the SDA according to radioactivity and container size, and then placed in a large pit (Pit 17) or in soil vaults (boreholes). Each filled pit or soil vault is covered with a minimum of $1 \mathrm{~m}(\sim 3 \mathrm{ft})$ of soil. Wastes contaminated with TRU elements in concentrations greater than $100 \mathrm{nCi} / \mathrm{g}$ are stored at the TSA in 208-L (55-gal) steel drums, fiberglass-covered wooden boxes, or steel bins.

Pad A, formerly called the Transuranic Disposal Area, is a prominent waste management area within the SDA. Pad A was originally an asphalt-surfaced area at the RWMC established to store uranium waste, primarily in the form of nitrate salts. The uranium waste contains enriched as well as depleted uranium. Some waste containing TRU elements were also placed on Pad A from 1972 to 1978. Most of the TRU waste contains less than $10 \mathrm{nCi} / \mathrm{g}$. However, a number of TRU waste drums are known to contain between 10 and $100 \mathrm{nCi} / \mathrm{g}$, and a very small percentage of drums contain greater than $100 \mathrm{nCi} / \mathrm{g}$. Waste containing beryllium is also stored on Pad A. When the pad was filled with stacked waste drums and boxes, the containers were covered with a $1 \mathrm{~m}(-3 \mathrm{ft})$ soil berm. Pad A was closed in November 1978.

Two facilities located in the TSA, the SWEPP building (see Figure 4 ) and the Certified and Segregated Waste Storage (C\&S) building, are used to examine stored TRU waste to ensure it meets the waste acceptance criteria of the Waste Isolation Pilot Plant (WIPP) located in New Mexico. Waste is retrieved, examined, and segregated into certifiable and uncertifiable waste packages. The certifiable waste packages will be prepared for shipment to WIPP. The C\&S building (TSA-3) is an air-supported storage building located on a $43 \times 254-\mathrm{m}(140 \times 834-\mathrm{ft})$ asphalt pad. The pad slopes from the center to the outer edges and from south to north. Drainage ditches on either side of the pad drain into sump pits.
The C\&S building and Pad R (south of TSA-1) are currently active for surface storage of waste contaminated with TRU elements in concentrations greater than $100 \mathrm{nCi} / \mathrm{g}$. In the past, waste containers were stacked on asphalt pads similar to $\mathrm{Pad} \mathrm{A}$ and covered with plywood, plastic, and soil when pad areas were filled. At present, drums of TRU waste are stored in TSA-3 on an asphalt pad and enclosed in an air-supported weather shield. Boxes of TRU waste are stored outside on Pad R. Retrieval of $\mathrm{Pad} R$ waste is planned, so this waste has been covered with vinyl-coated nylon.

Transuranic waste with high radiation levels (greater than $200 \mathrm{mR} / \mathrm{h}$ at contact) requiring remote handling is stored at the IntermediateLevel Transuranic Storage Facility (ILTSF) within the TSA. Such waste is stored in subsurface, cylindrical metal vaults capped with removable shield plugs.

The Drum Vent System (DVS) facility remotely vents TRU waste drums and inserts a carbon-bonded filter assembly. The filter assembly allows aspiration of internally generated gases while containing radioactive particulates inside the drum. The DVS facility operated for a short time during 1992. This special project was in support of the WIPP Experimental Bin Test. During June, July, and August of 1992 the facility processed 185 drums.

\section{Waste Experimental Reduction Facility}

The WERF is located in the south-central portion of the INEL (see Figure 5), about $8 \mathrm{~km}$ ( $5 \mathrm{mi}$ ) southeast of the Central Facilities Area (CFA). It is located in the decommissioned and modified Special Power Excursion Reactor Test (SPERT) facility, and consists of a concrete block building (PER-609), with high bay and basement operating areas. Incineration, compaction, metal melting, and solidification processes are conducted in this facility. Waste sorting and bulk scrap metal sizing activities are performed in a metal building (PER-635) located to the northeast of PER-609. Transient storage pads for preand post-process waste are located adjacent to the facility. 


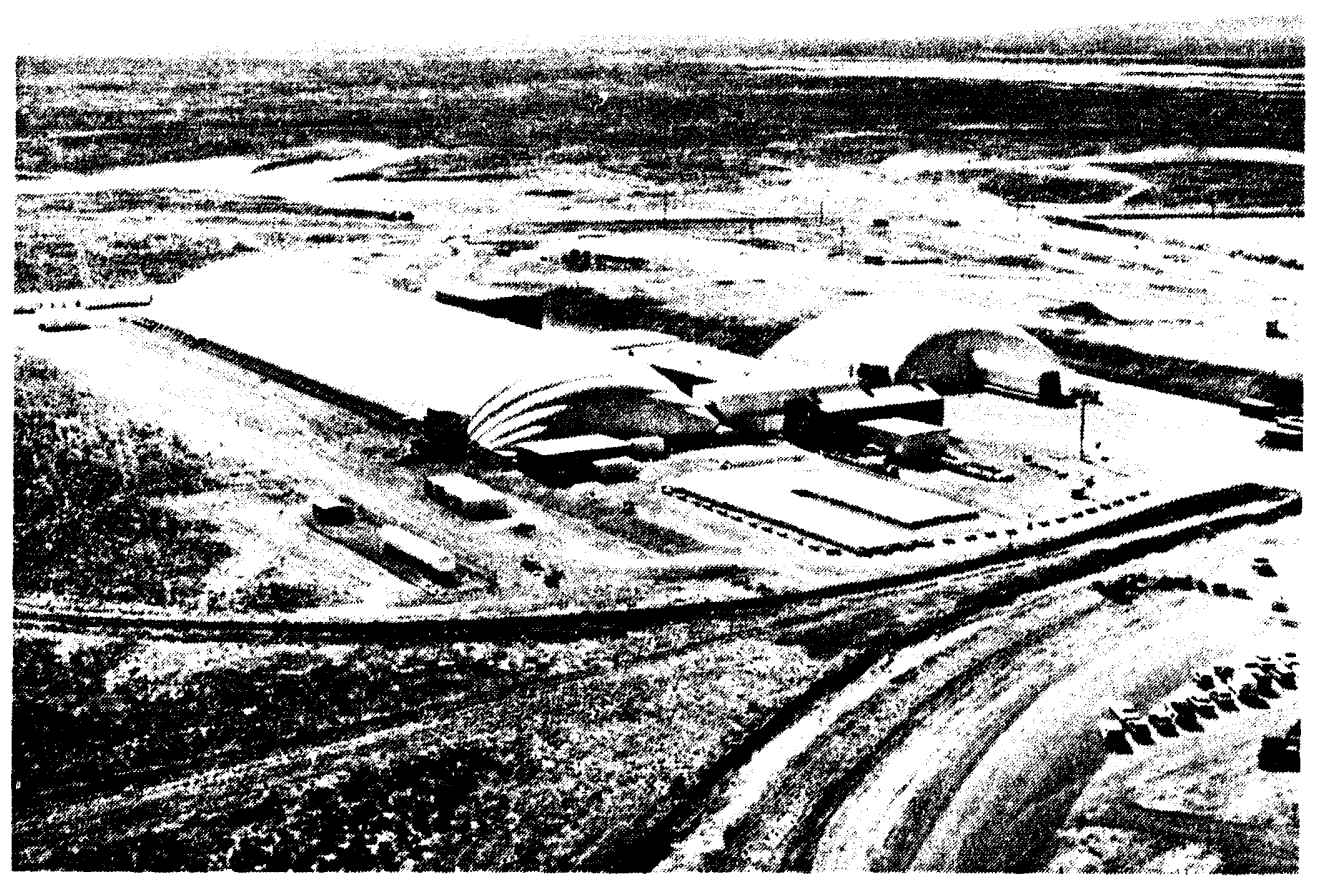

Figure 4. Aerial photograph of the Stored Waste Examination Pilot Plant (facing south).

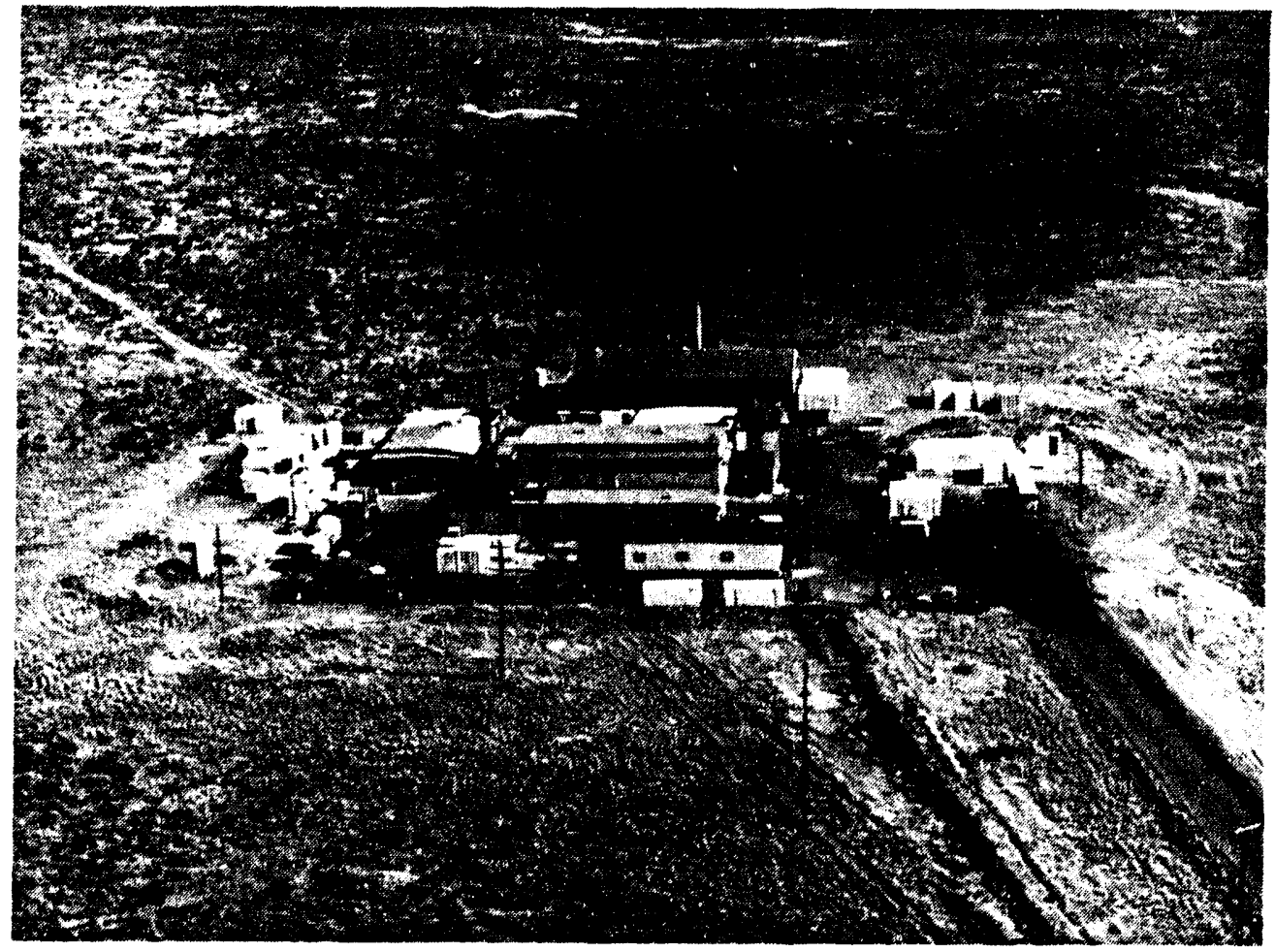

Figure 5. Aerial photograph of the Waste Experimental Reduction Facility (facing east). 
The WERF was established in 1982 for the research and development of production scale, volume-reduction methods for low-level beta/ gamma-contaminated metals and combustible materials. This facility is now used to size-reduce and melt radiologically contaminated metal, compact nonincinerable waste, incinerate radiologically contaminated combustible waste, and stabilize the resultant fly-ash by solidification. Exhaust gases from WERF activities are filtered in a baghouse filter and a high-efficiency particulate air (HEPA) filter prior to discharge.

\section{Stationary Low-Power No. 1 Surplus Area}

The SL-1 surplus area is located in the south central portion of the INEL, about $7.2 \mathrm{~km}$ (4.5 $\mathrm{mi})$ north of the southern INEL boundary. The total area within the SL-1 Burial Ground fence is about 1.7 ha (4.2 acres). No surface facilities have been constructed within the exclusion fence. The area contains most of the SL-1 dismantled reactor building, radiologically contaminated equipment, about $750 \mathrm{~m}^{3}\left(26,486 \mathrm{ft}^{3}\right)$ of radiologically contaminated dirt and gravel, and decontamination waste in one trench and two pits.

\section{Organic-Moderated Reactor Experiment}

The OMRE area is located in the south-central portion of the INEL, about $7.6 \mathrm{~km}(4.7 \mathrm{mi})$ north of the southern INEL boundary, and occupies about 1.2 ha ( 3 acres). The OMRE project was completed in 1963, and the facility was decontaminated and decommissioned in 1979. The building and underground reactor were disassembled, the radiologically contaminated material was disposed of at the RWMC, and uncontaminated parts were sold as scrap. The leach pond was backfilled with soil, and the entire area was revegetated with a mixture of native grasses in 1981. No waste was buried within the OMRE boundaries, and no surface facilities exist today.

\section{Mixed Waste Storage Facllity}

The MWSF is the temporary storage facility for mixed waste at the INEL. It is housed in the decontaminated and decommissioned SPERT-IV reactor building (PBF-613). The building, which was constructed in 1960, consists of a high bay and two low-bay wings. The high bay is a $22 \times 15 \times 14-\mathrm{m}(73 \times 48 \times 44.5-\mathrm{ft})$ steel-girded, reinforced concrete, cinder block structure with a 27-ft-deep basement, and a metal roof. The total capacity of stored mixed waste is $365,55-\mathrm{gal}$ drums, or equivalent. Cargo containers in the parking area adjacent to the MWSF are used for storage of mixed waste solids, including lead. No flammable liquids or solids or reactive wastes are stored in the cargo containers. 


\section{MONITORING METHODS AND RESULTS}

The remainder of this report discusses the monitoring methods and 1992 results. The major subject is radiological monitoring of EG\&G Idaho-operated Waste Management facilities, which includes the following topics: (a) airborne particulates, (b) RWMC surface water run-off, (c) soils, (d) biota (vegetation and small mammals), (e) penetrating radiation, and (f) surface radiation. Table 1 shows the RESP activities performed at these Waste Management facilities.

Subsurface water monitoring at the RWMC by the USGS is also discussed.

Also included are appendices discussing quality assurance (QA), detection limits, statistical methods, and environmental standards. Detailed information on radiological analyses of all sample media is in Appendix B.

\section{Ambient Air Monitoring}

Ambient air was sampled for radioactive particulates during 1992 at the RWMC, WERF, and MWSF. In addition to the general RESP objectives, the specific objectives of the ambient air sampling were as follows: (a) determine concentrations of airborne radionuclides in the vicinity of EG\&G Idaho Waste Management facilities, (b) report comparisons of measured concentrations to reference levels based on derived concentration guides (DCGs) for the public given in DOE Order $5400.5,{ }^{9}$ and (c) detect and report significant trends in measured concentrations of airborne radionuclides.

Air is considered to be a critical pathway of contaminants through the environment. ${ }^{10} \mathrm{Air}$ borne materials from the RWMC are predominantly fugitive dusts with small amounts of sorbed radionuclides. The general approach to monitoring an area source, such as the fugitive dusts at the RWMC, is to monitor the perimeter of the facility.

The 1983 monitoring activities review (MAR) (EGG 1983a) provides much of the rationale for the current ambient air monitoring design. ${ }^{11}$ Following the MAR recommendations, the number of high-volume (HV) air monitor locations around the SDA was reduced to seven. The MAR recommendations were based on the identification of redundant samplers, using statistical comparisons of data with time and location. In response to MAR comments, a replicate sampler and a control location were also added to the air monitoring system. In addition, based on the MAR comments, $\mathrm{HV}$ air monitors were replaced in 1986 with low-volume (LV) air monitors (see Figure 6) that operate at $0.14 \mathrm{~m}^{3} / \mathrm{min}(5 \mathrm{cfm})$. Particulate material is collected on a membrane filter (Gelman Model Versapor-1200, $1.2 \mu \mathrm{m}$, $102 \mathrm{~mm}$ diameter).

During July, most of the existing total suspended particulate (TSP) air monitors were replaced with intermediate flow $\mathrm{PM}_{10}$ air monitors (see Figure 7). These new $\mathrm{PM}_{10}$ air monitors use the same membrane filter as the TSP air monitors and sample particulates less than $10 \mu \mathrm{m}$ in size which includes the respirable fraction. Measuring the respirable fraction provides data which meets the general RESP objective for providing data which may be used for dose calculations. Also, the $\mathrm{PM}_{10}$ s continuously sample air at a rate of $0.11 \mathrm{~m}^{3} / \mathrm{min}(4 \mathrm{cfm})$.

TSP air monitors remain at strategic locations at RWMC and WERF including location 300 of WERF (see Figures 8, 9, and 10). One air monitor remains at location 2 of the SDA while two others remain at locations 20 and 26 of SWEPP.

Replicate samples are taken at location 4 at the RWMC (see Figures 8 and 9). The control sample location for the RWMC is at the Experimental Breeder Reactor-I (EBR-I) area, approximately $3 \mathrm{~km}(1.9 \mathrm{mi})$ east-northeast of the RWMC. The WERF control sample location, which serves both WERF and MWSF, was next to the INEL Main Gate, Building 603 (see Figure 11). The prime factors influencing the selection of sampler locations were prevailing wind patterns, accessibility, and availability of electrical power. 


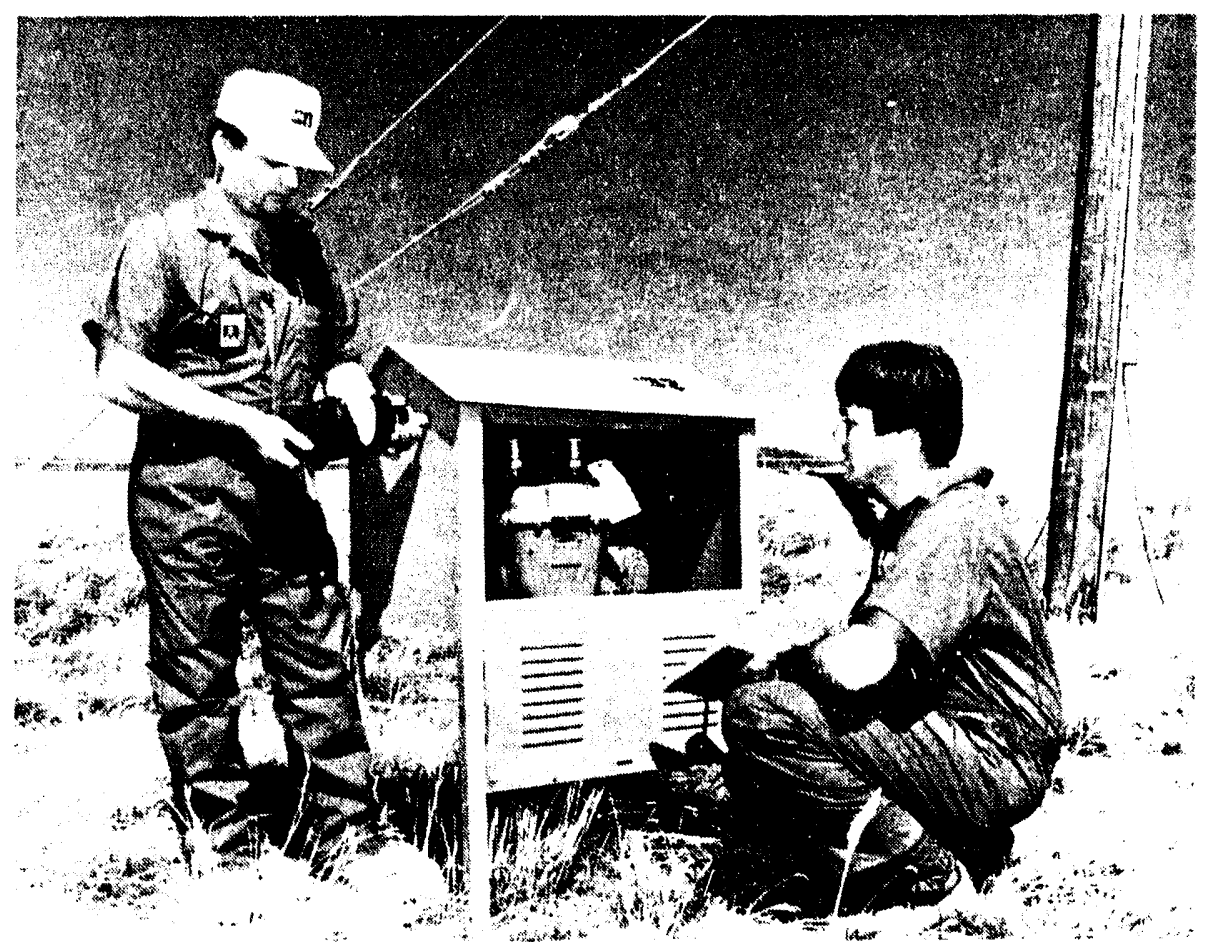

Figure 6. Collection of particulate air filter from LV air sampler. 


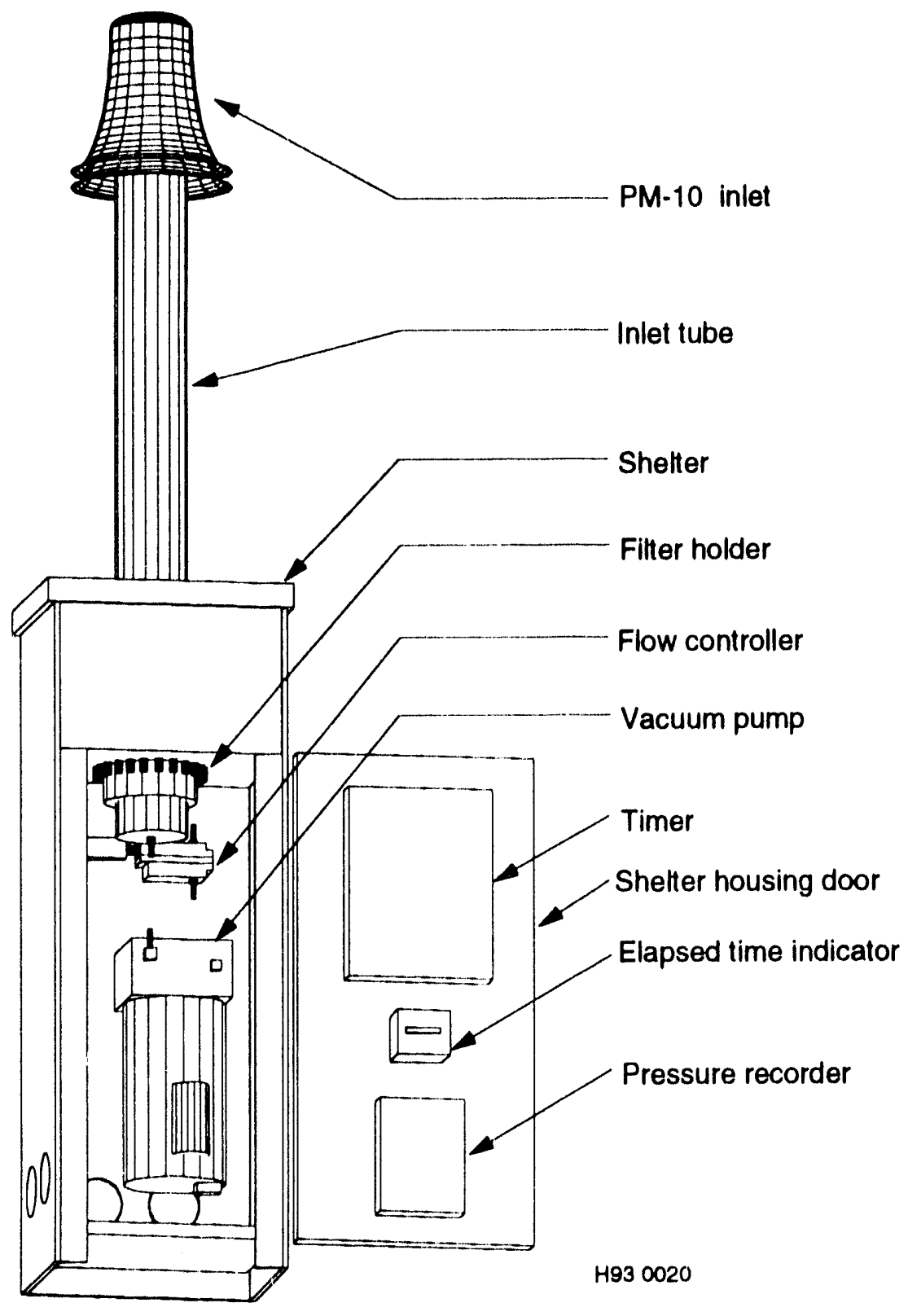

Figure 7. $\mathrm{PM}_{10}$ air monitor. 


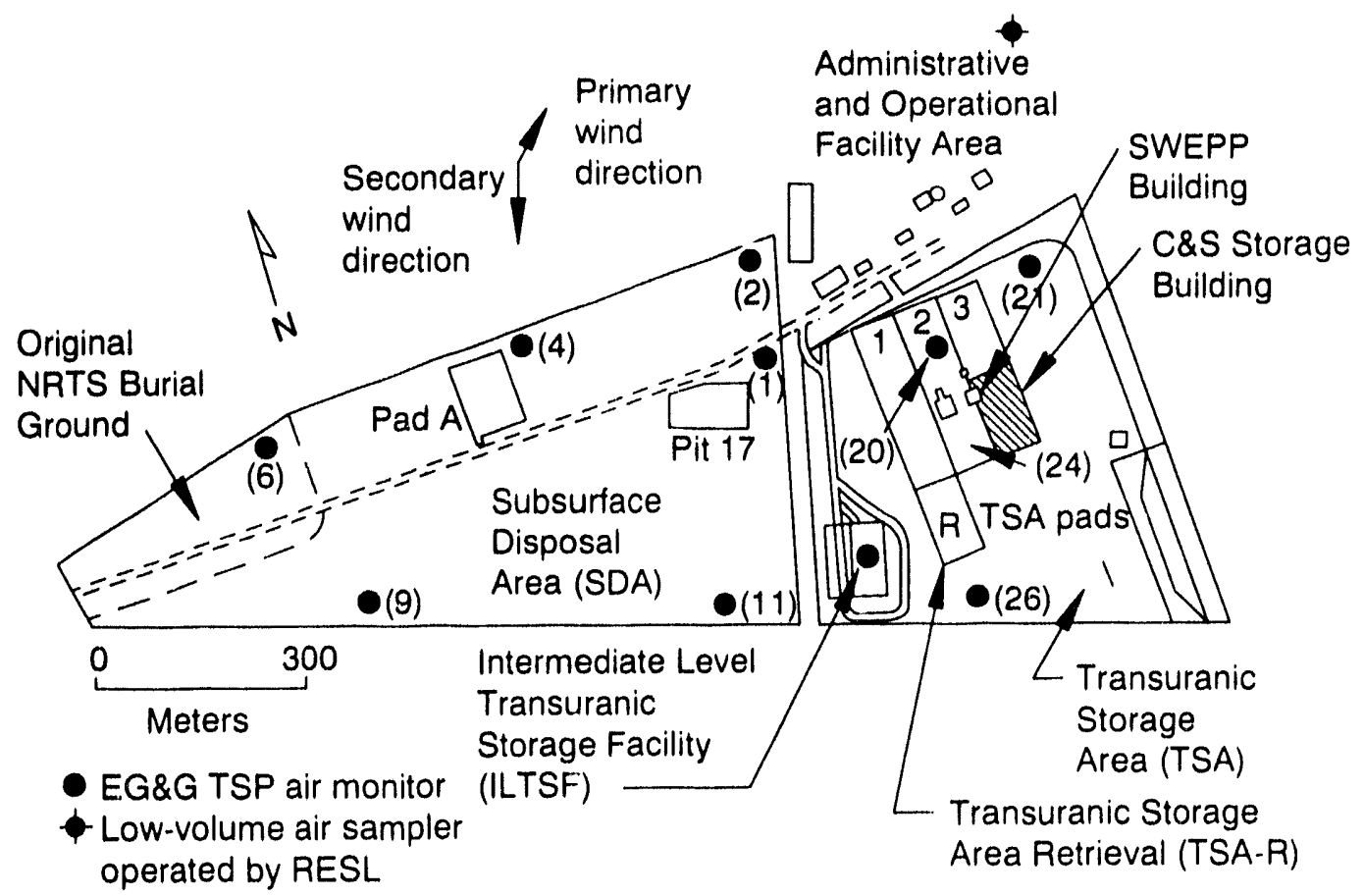

2930550

Figure 8. RWMC TSP air monitoring locations prior to July 2, 1992.

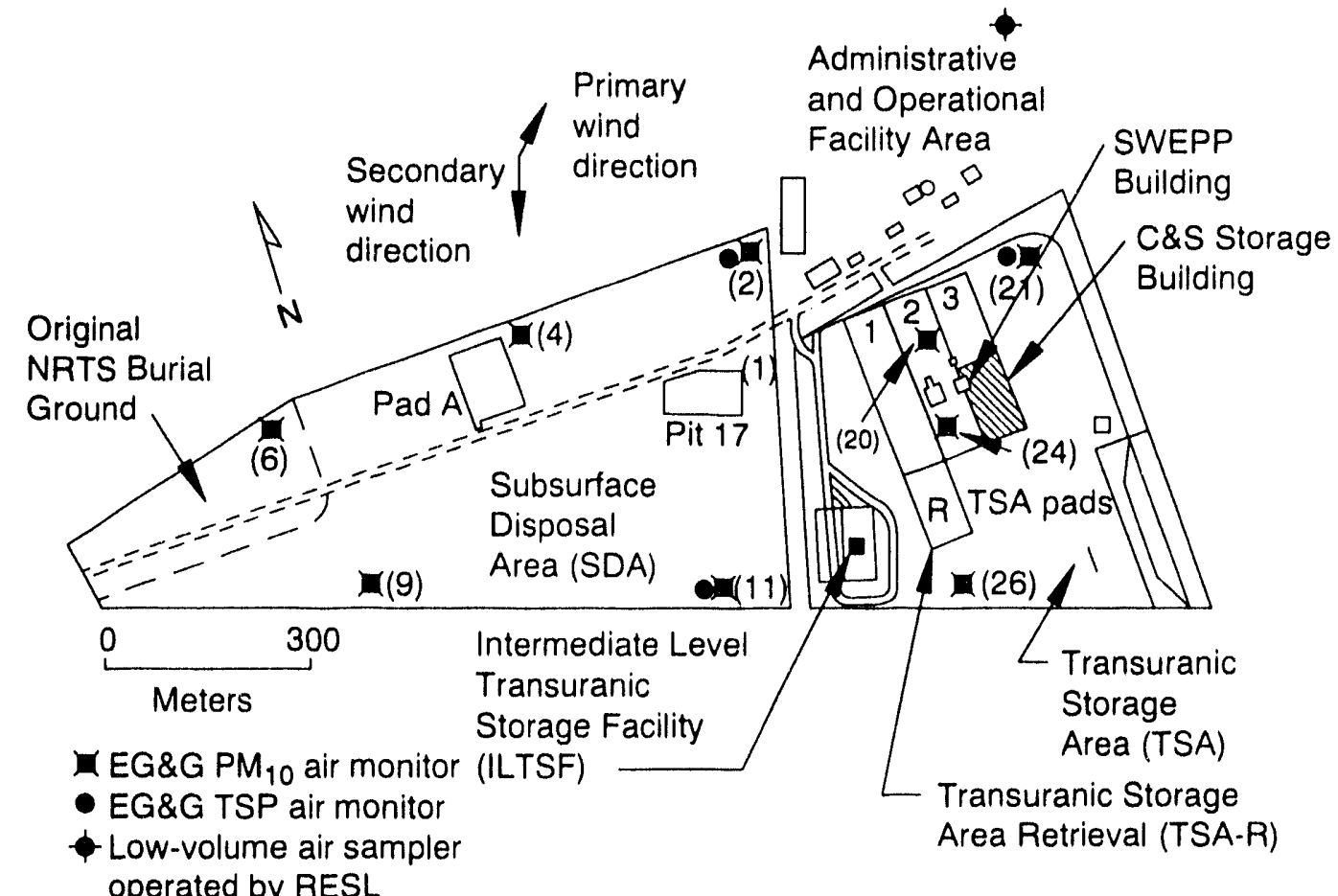

Figure 9. RWMC TSP and $\mathrm{PM}_{10}$ air monitor locations after July 2, 1992. 


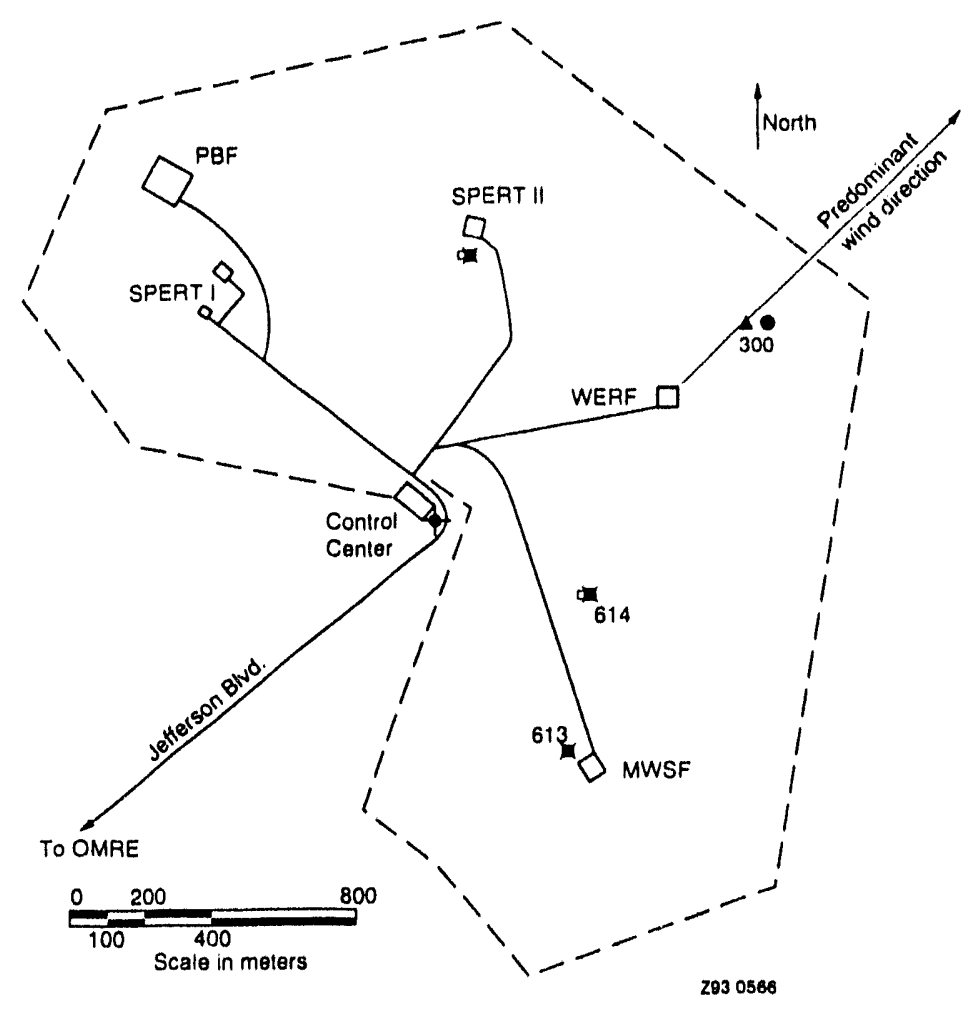

- EG\&G PM10 air monitor

- EG\&G TSP air monilor

$\uparrow$ RESL low.volume air sampler

Figure 10. WERF air monitoring locations.

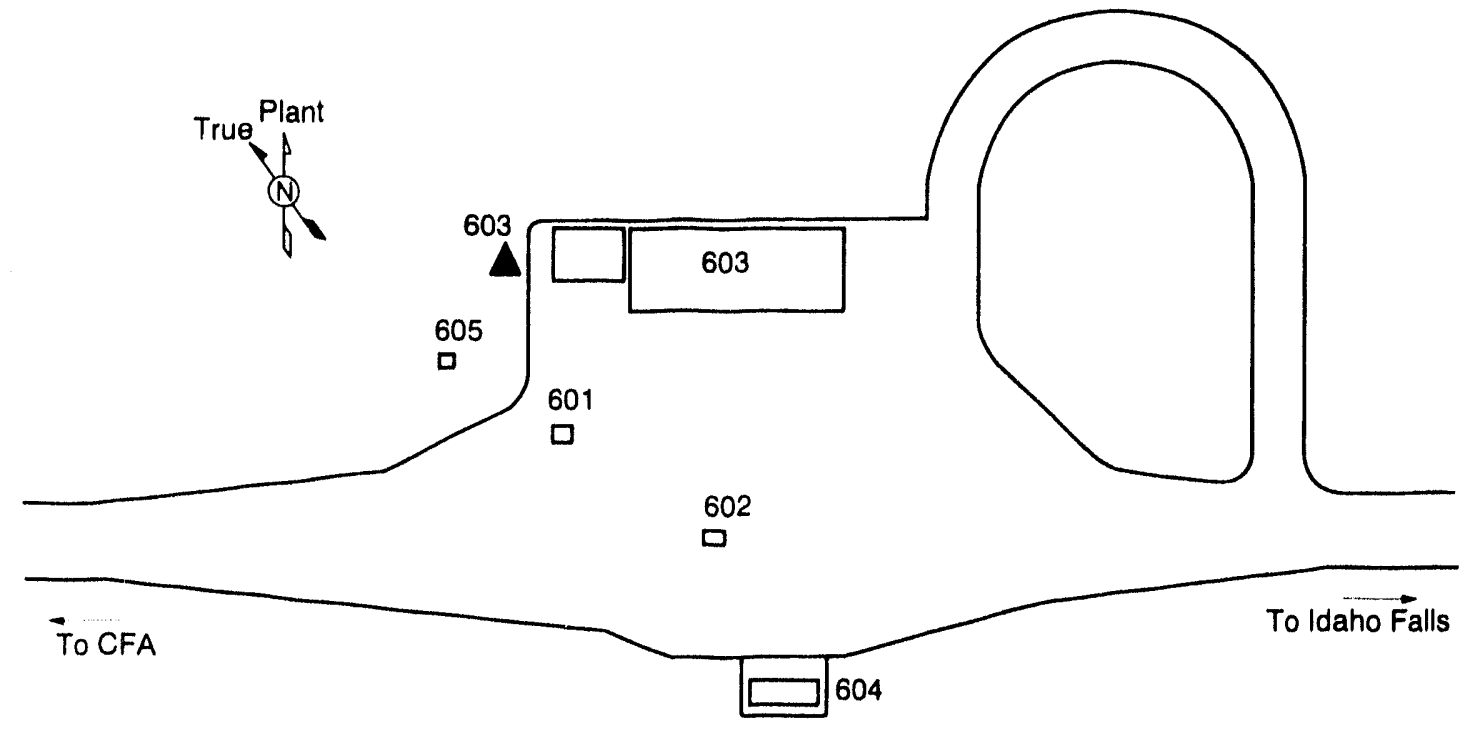

V91 0021

\section{A low.volume air sampler location}

Figure 11. WERF air monitoring control location. 
The RESL also maintains several LV air monitors near EG\&G Idaho-managed facilities and at off-Site locations (see Figure 12). One air monitor is located at RWMC, PBF, and EBR-I. The RESL's samplers operate at about $0.04 \mathrm{~m}^{3} / \mathrm{min}$ $(1.5 \mathrm{cfm})$ through a set of filters consisting of a membrane filter (Gelman Model V-1200) followed by an activated charcoal cartridge filter (Radeco Model B6-300). These filters are 99\% efficient for removal of radioactive airborne particulates and elemental iodine vapor from ambient air.

EG\&G Idaho air filters were collected and analyzed semimonthly for gross alpha and gross beta activity, and monthly composites at each location are analyzed quantitatively for gamma-emitting radionuclides. All filters from the RWMC are also composited on a quarterly basis and analyzed for specific alpha- and beta-emitting radionuclides. The statistical approach applied to analyze the data is presented in Appendix C. RESP samples are compared to data supplied by RESL from air monitors located both on-- and off-Site.

The primary purpose of gross alpha analysis is to detect significant changes in concentration of airborne alpha activity at the RWMC. The gross alpha results are also used as a criterion to screen samples for immediate radiochemical analyses for specific alpha-emitters.

Results of gross beta analysis of the air filters are evaluated to determine if there are any significant increases in the sample radioactivity that may require more immediate and/or more indepth analysis by gamma spectrometry or radiochemistry. Gross beta analysis is thus used as a quick and inexpensive screening tool. The results are also used to indicate any trends in environmental radioactivity.

EG\&G Idaho evaluates gross beta results semimonthly by comparing them with historical and background data for an indication of trends, using a log concentration-versus-time plot. Control concentrations, detection limits, and alert levels are compared for each plot. Alert levels are $25 \%$ of the most restrictive DCGs for the public. Comparisons are made between stations and with the control samplers, using analysis of variance (see Appendix C). The RESP also compares gross beta activity to DCGs. Measured concentrations are compared to the DCGs as a point of reference for interpreting the results (see Appendix D). $\mathrm{Sr}-90$ and $\mathrm{Cs}-137$ are the most likely wasterelated beta-emitting radionuclides to be found at the RWMC. Of these two, Sr-90 has the more restrictive DCG. For this reason, the Sr-90 DCG was adopted as the equivalent gross beta DCG for airborne particulates (see Appendix D). (Pu-24l is also a low-energy beta-emitter and has a more restrictive DCG than $\mathrm{Sr}-90$; however, it is generally detected through its alpha- and gammaemitting daughter, Am-241.)

\section{Radioactive Waste Management Complex}

Figures 8 and 9 show the sampling locations of both EG\&G Idaho's and RESL's air monitors at the RWMC. EG\&G Idaho has measured gross beta activity since 1979. Quarterly averages of RWMC gross beta activity (Cs-137 equivalent) are given in Figure 13. The rise in beta activity from late 1980 through 1981 is attributed to the fallout from an October 1980 atmospheric nuclear detonation by the People's Republic of China.

The rise in beta activity in 1986 is attributed to the fallout from the April 1986 Chernobyl accident in the Soviet Union. The control values prior to 1983 are not shown in Figure 13 since the RWMC control location was not established until 1983.

Figures 14 and 15 show the maximum gross beta concentrations ( $\mathrm{Cs}-137$ equivalent) at the SDA and SWEPP, respectively, during each semimonthly sample period during 1992. The gross beta data have historically followed a seasonal trend that usually increases during the latter part of the year. This same pattern was noted while trending the 1992 data. 
- Craters of the Moon

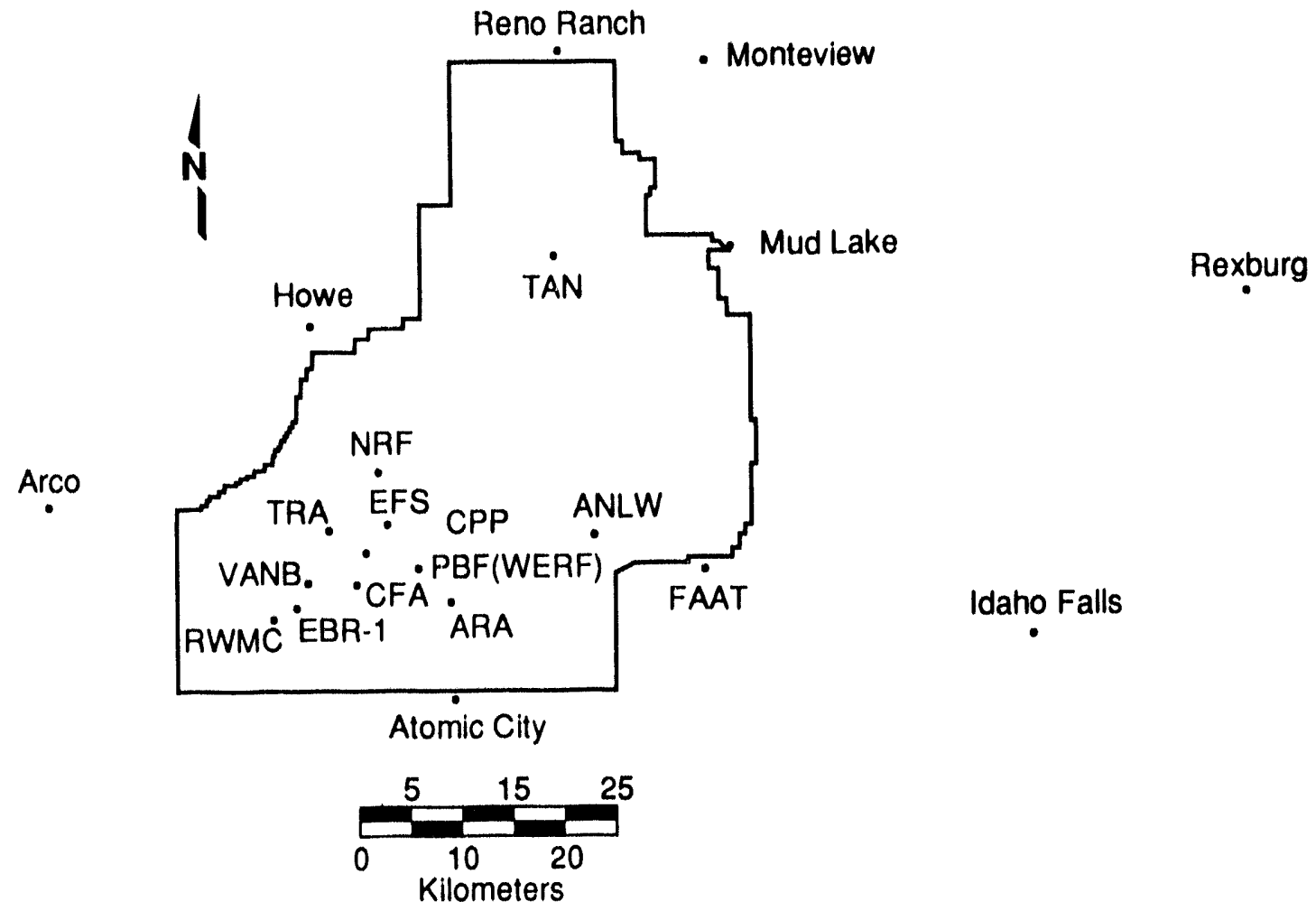

- RESL Low-volume air samplers

\section{Blackfoot}

B93 0033

Figure 12. RESL's air sampling network at the INEL and vicinity.

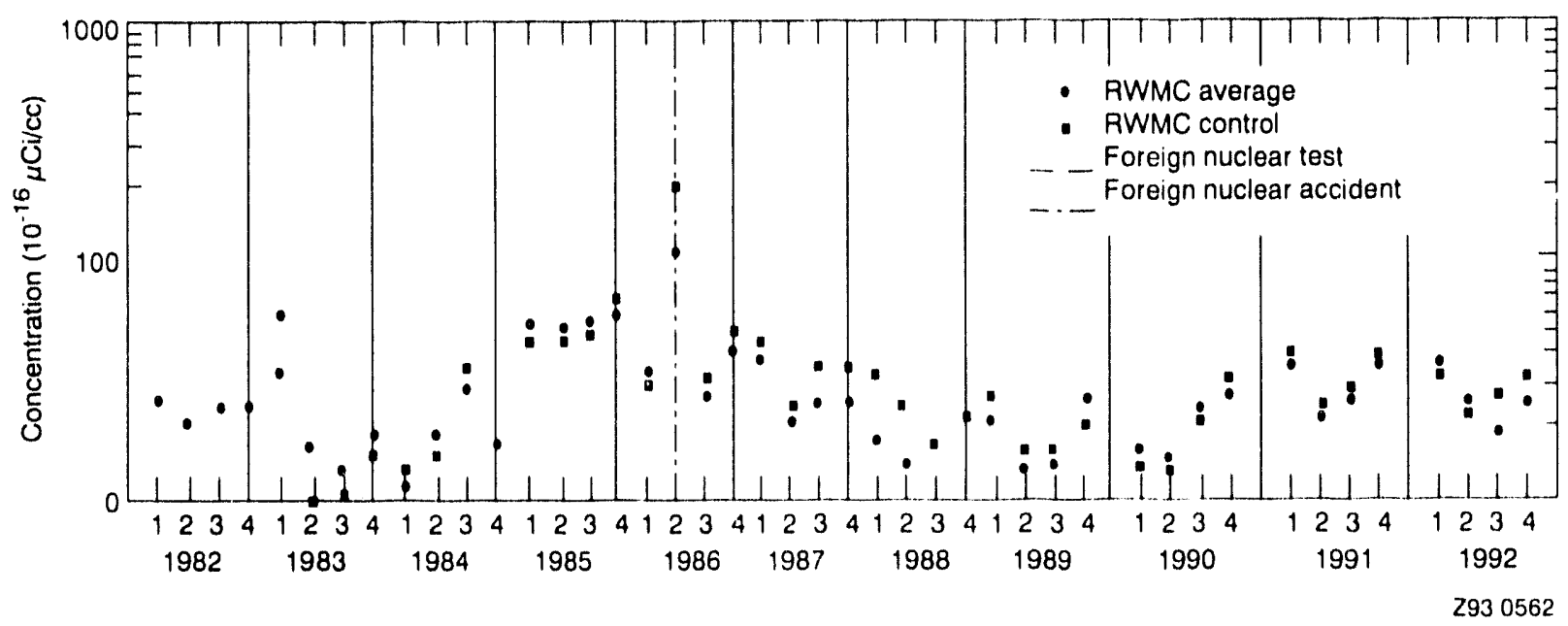

Figure 13. Quarterly averages of RWMC gross beta air concentrations since 1979. 


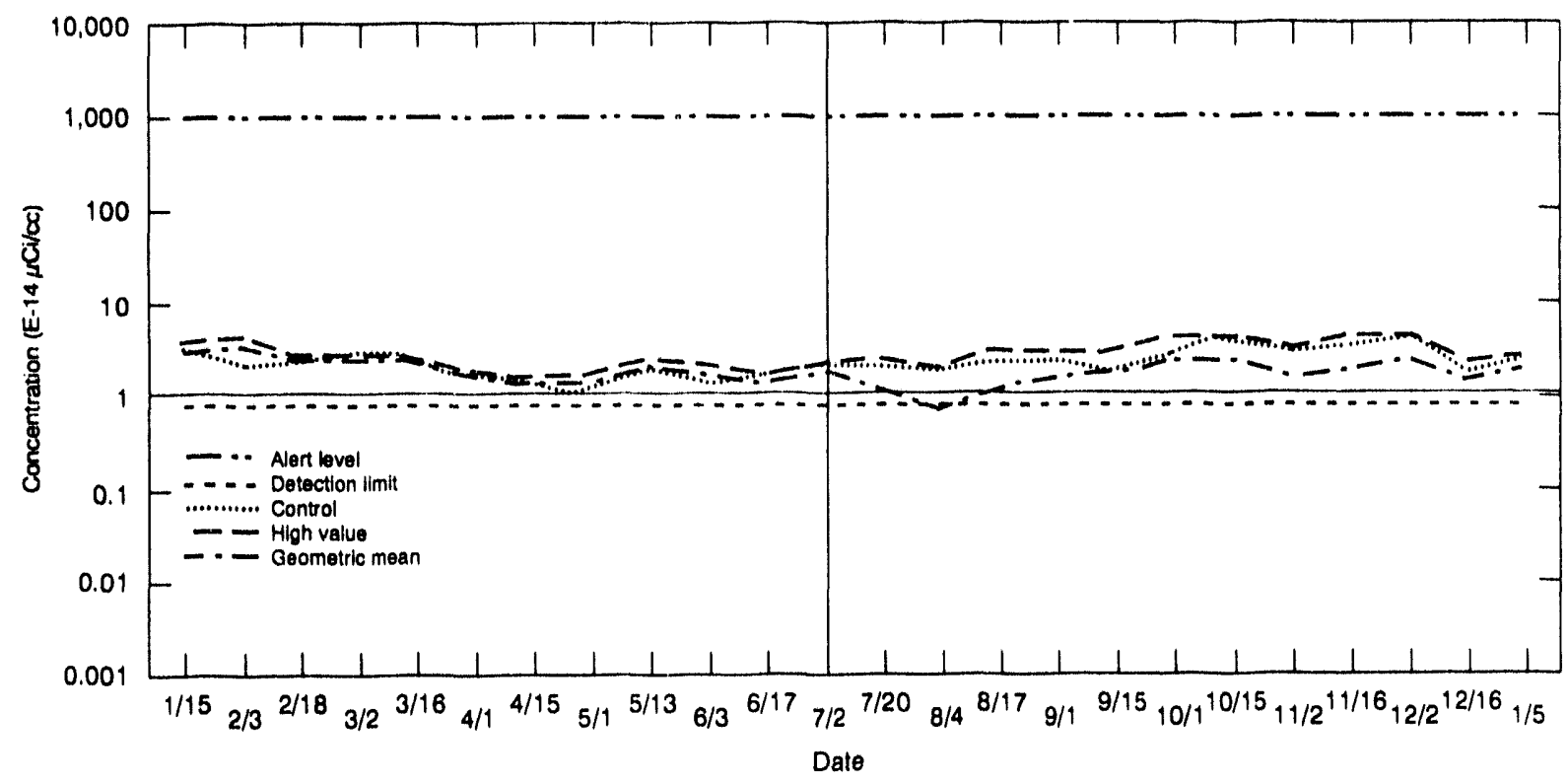

Note: Une starting on $7 / 2$ indicates new $\mathrm{PM}_{10}$ air monitors.

2930560

Figure 14. Maximum gross beta concentrations (Cs-1.37 equivalent) for SDA air filters during each semimonthly period of 1992.

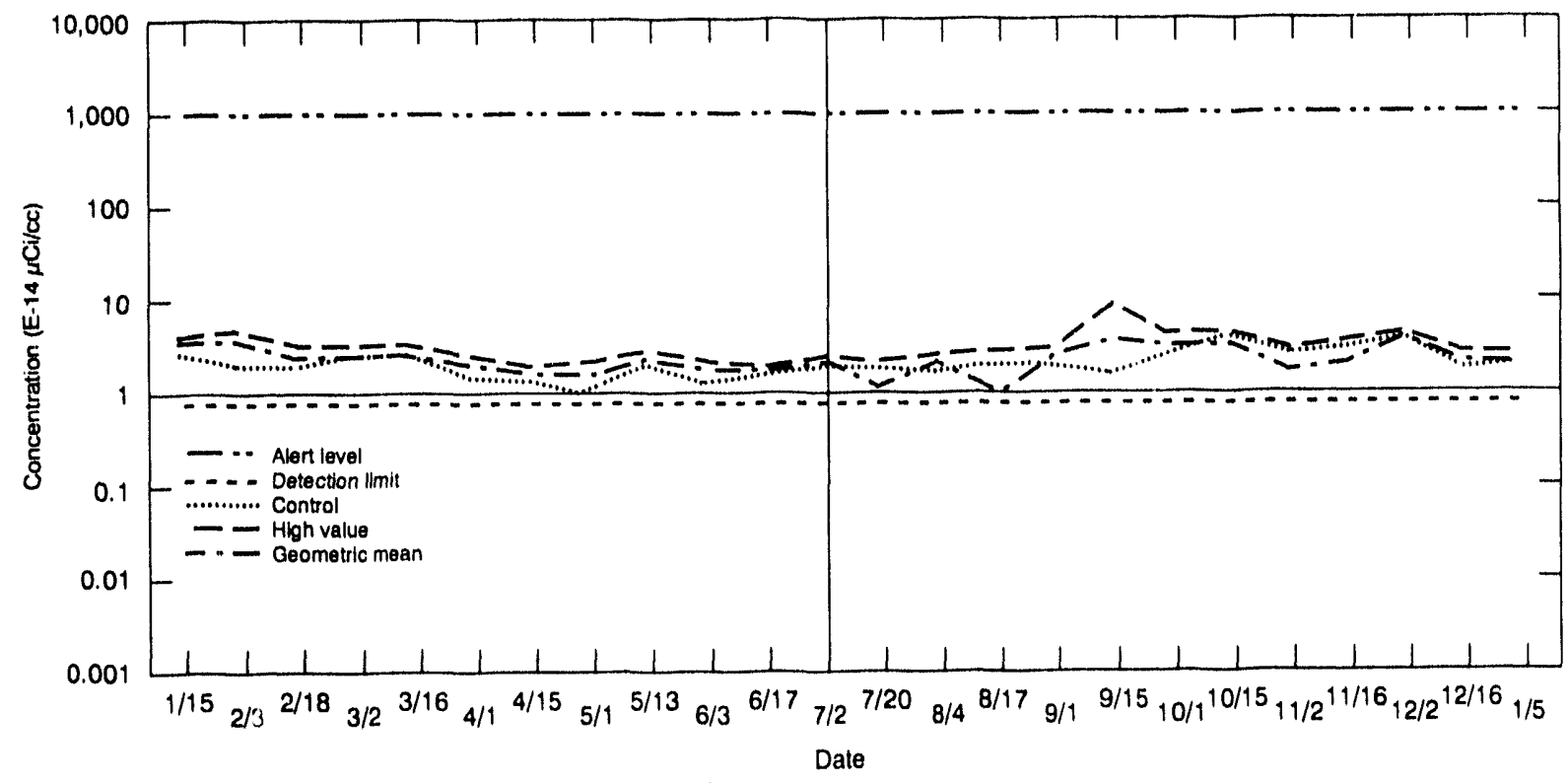

Note: Line starting on $7 / 2$ indicates new $\mathrm{PM}_{10}$ air monitors.

2930559

Figure 15. Maximum gross beta concentrations (Cs-137 equivalent) for SWEPP air filters during each semimonthly period of 1992. 


\section{Trend Analysis}

Due to replacing the TSP air monitors with the $\mathrm{PM}_{10}$ air monitors, trends were treated separately for each air monitor type. Graphs of gross alpha and gross beta concentrations over time are shown in Figures 16 through 19.

To provide an indication of the general trend in values over time, data in the graphs were smoothed using a statistical technique called polynomial smoothing. Fifth order polynomials were used to fit the sample data for the TSP air monitors. Third order polynomials were used to fit the sample data for the $\mathrm{PM}_{10}$ data to reflect the shorter time period over which data were available. Both gross alpha and gross beta concentrations declined from January until about the late July to early August. After the July-August time frame, activity levels increased again, reaching another peak in late November or early December. Values declined again in the last two time periods of the year. Year end values were generally lower than the beginning values.

Monthly averages of RESL's LV air samples at the RWMC for particulate beta activity are given in Figure 20. RESL's data and EG\&G data shows a similar trend.

\section{Analysis for Gamma-Emitting Radionu- clides}

Gamma-emitting radionuclides that could be present due to RWMC operations were not detected in either the RESP or RESL air samples collected at the RWMC in 1992. (Radionuclides most likely to be found at the RWMC, and detection limits, are listed in Table B-2 of Appendix B.)

\section{Analysis for Specific Alpha- and Beta- Emitting Radionuclides}

Only four data points are collected per location in any year, with results frequently less than the detection limit. Consequently, it is not generally possible to develop trend information over a oneyear period, nor is it possible to obtain information regarding the time of a release within a one-quarter period.
Figure 21 shows a plot of $\mathrm{Pu}-239,-240$ and Am-241 concentrations measured at all RWMC locations since the first quarter of 1986 and their association to the appropriate DCG. These radionuclides were plotted because they were usually detected as a minimum on an annual basis. Also, these radionuclides were instrumental in identifying and evaluating the breached container containing alpha-emitting radionuclides at the TSA-R Pad that occurred during 1986 through 1988.

The 1987 environmental surveillance report ${ }^{12}$ described elevated airborne TRU activity in the SDA and TSA areas. Breached containers were discovered on the TSA-R Pad in late spring, 1988, and actions were taken immediately to isolate the containers and stop the spread of contamination. The decrease in TRU activity during 1989 (compared to activity of previous years) further demonstrates that the increased activity during 1986 through 1988 was most likely due to the breached waste containers found in 1988.

During the first and third quarters of 1992 , Am-241 W.s detected in composite air samples from SDA locations 2 and 4. Thes: detections indicate relatively low levels of airborne activity, with the maximum concentration of $9.4 \pm 1.7$ $\mathrm{E}-18 \mu \mathrm{Ci} / \mathrm{cc}$. This concentration corresponds to $0.05 \%$ of the DCG for airborne releases of Am-24I to the public. These concentrations are mostly from resuspended soil around the previously flooded areas and are below concentrations detected in previous years.

During the second quarter, two low-level detections of $\mathrm{Pu}-239,-240$ were noted at SDA locations 2 and 6 with the maximum concentration being $9.6 \pm 1.6 \mathrm{E}-18 \mu \mathrm{Ci} / \mathrm{cc}$. This concentration correspoids to $0.03 \%$ of the DCG for airborne releases to the public. This concentration was also noted in previous samples collected at the SDA and around the previously flooded areas. These two detections were the only detections of $\mathrm{Pu}-239,-240$ noted during 1992. No specific alpha- and beta-emitting radionuclides were detected during the fourth quarter. 


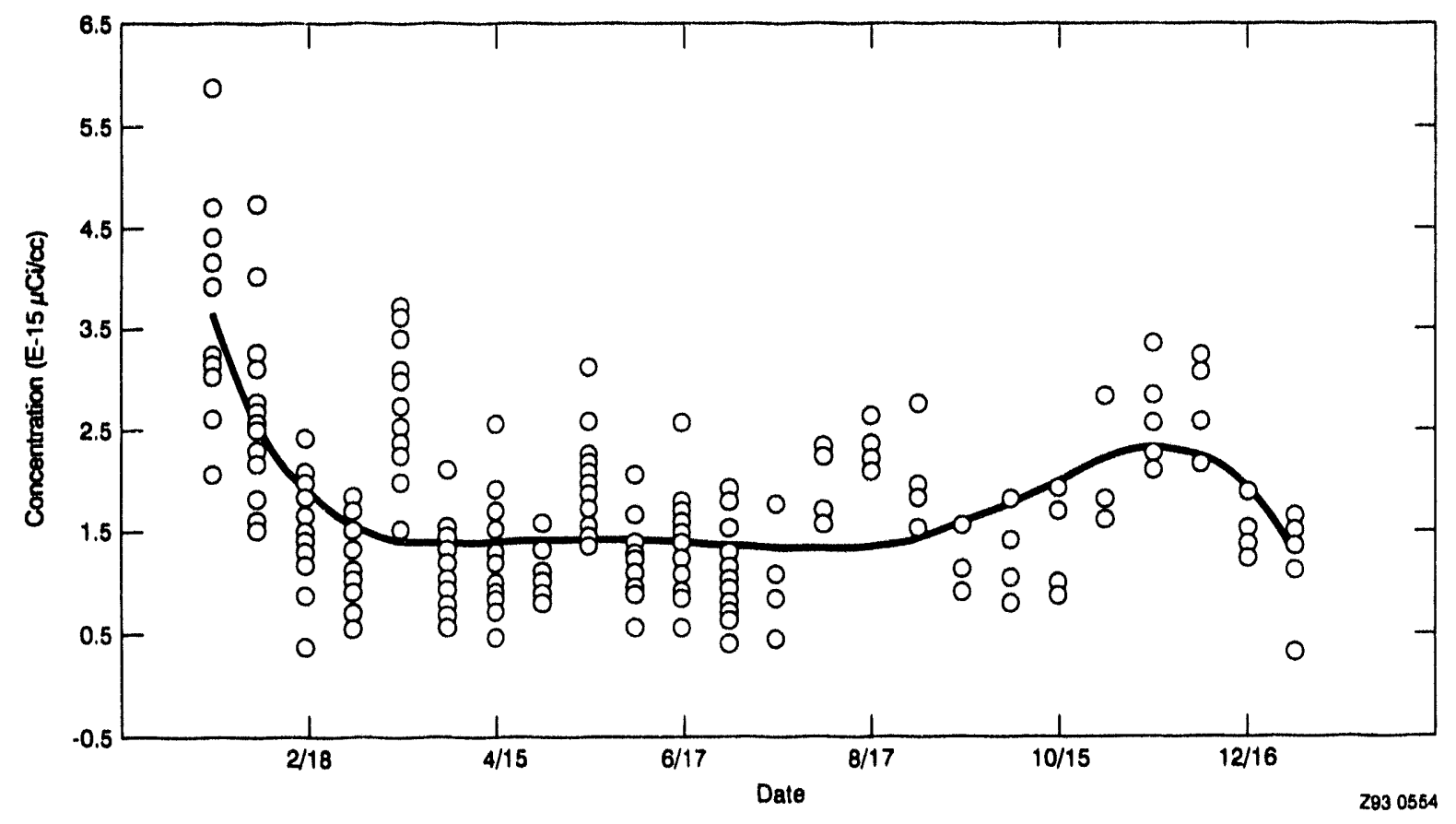

Figure 16. 1992 gross alpha concentrations for TSP air monitors using fifth order polynomial smoothing.

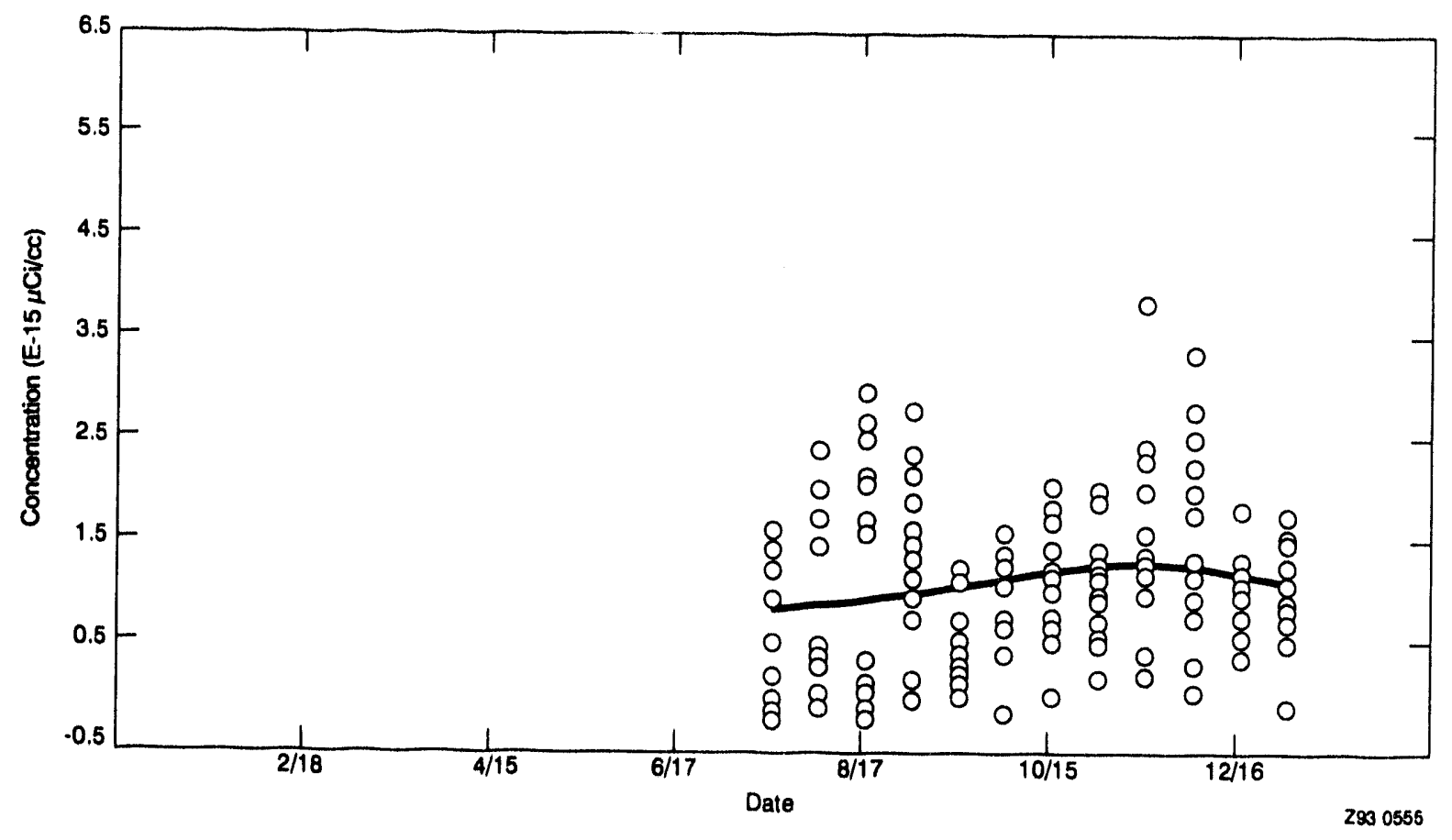

Figure 17. 1992 gross alpha concentrations for $\mathrm{PM}_{10}$ air monitors using third order polynomial smoothing. 


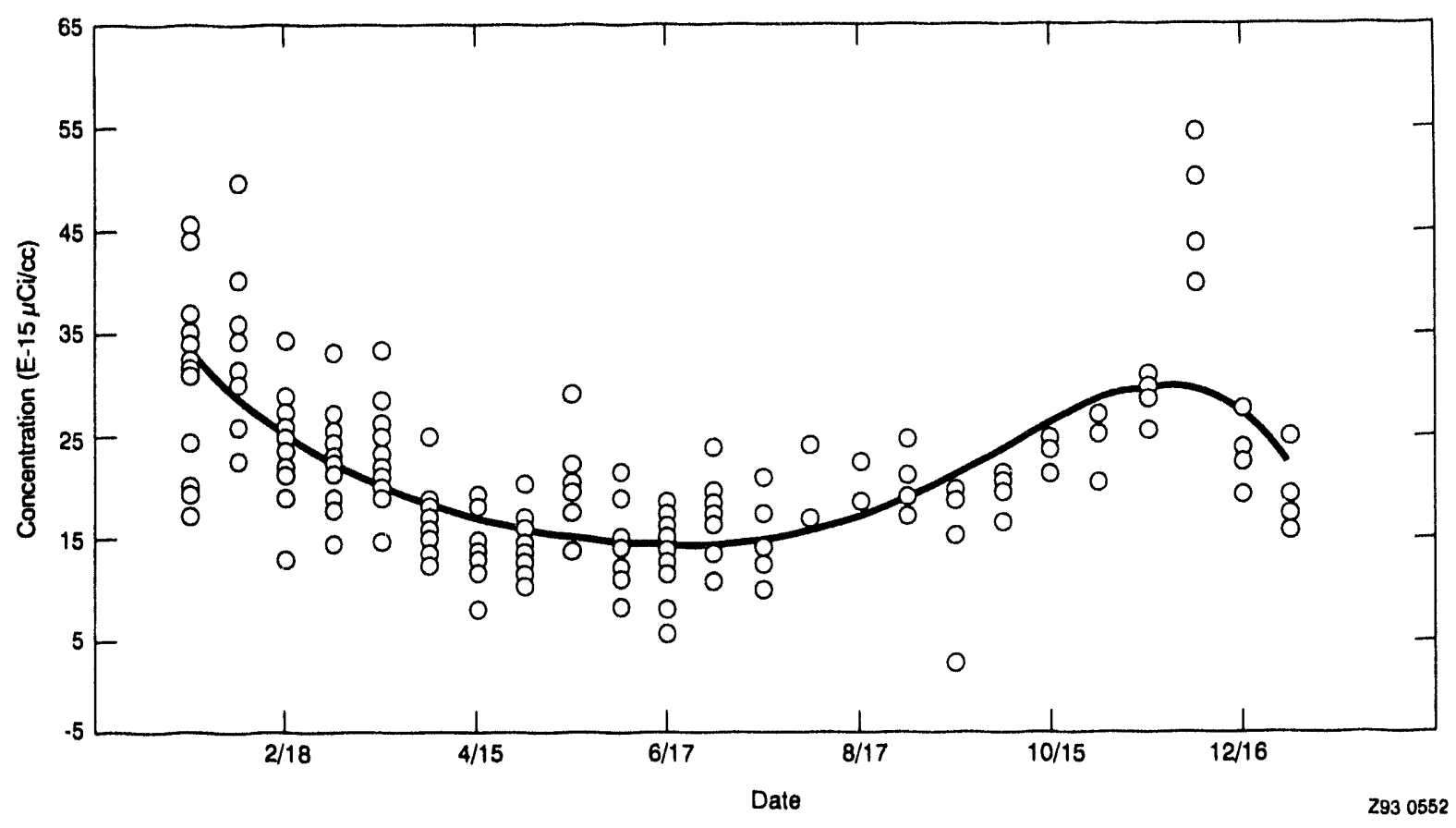

Figure 18. 1992 gross beta concentrations for TSP air monitors using fifth order polynomial smoothing.

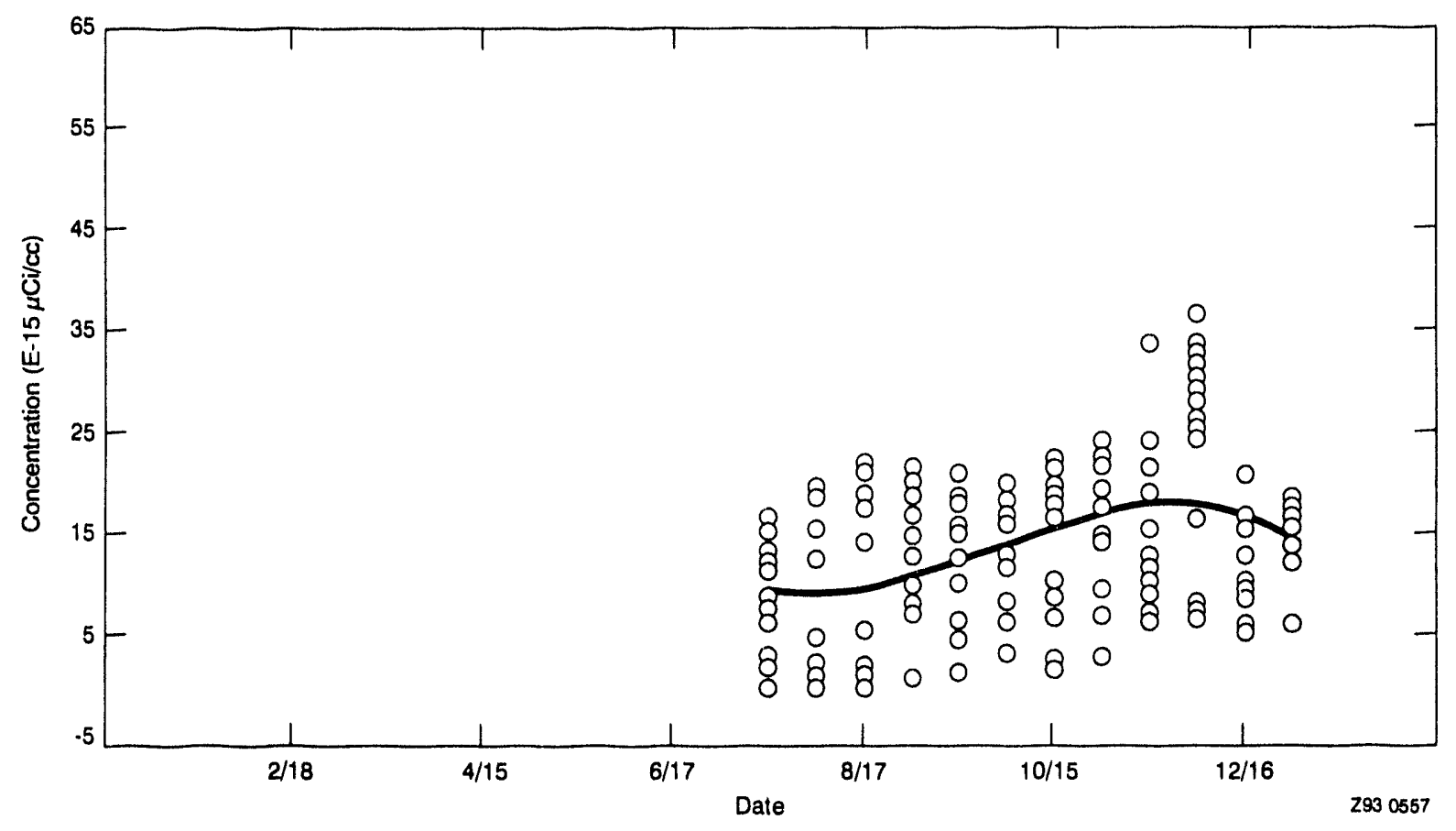

Figure 19. 1992 gross beta concentrations for $\mathrm{PM}_{10}$ air monitors using third order polynomial smoothing. 


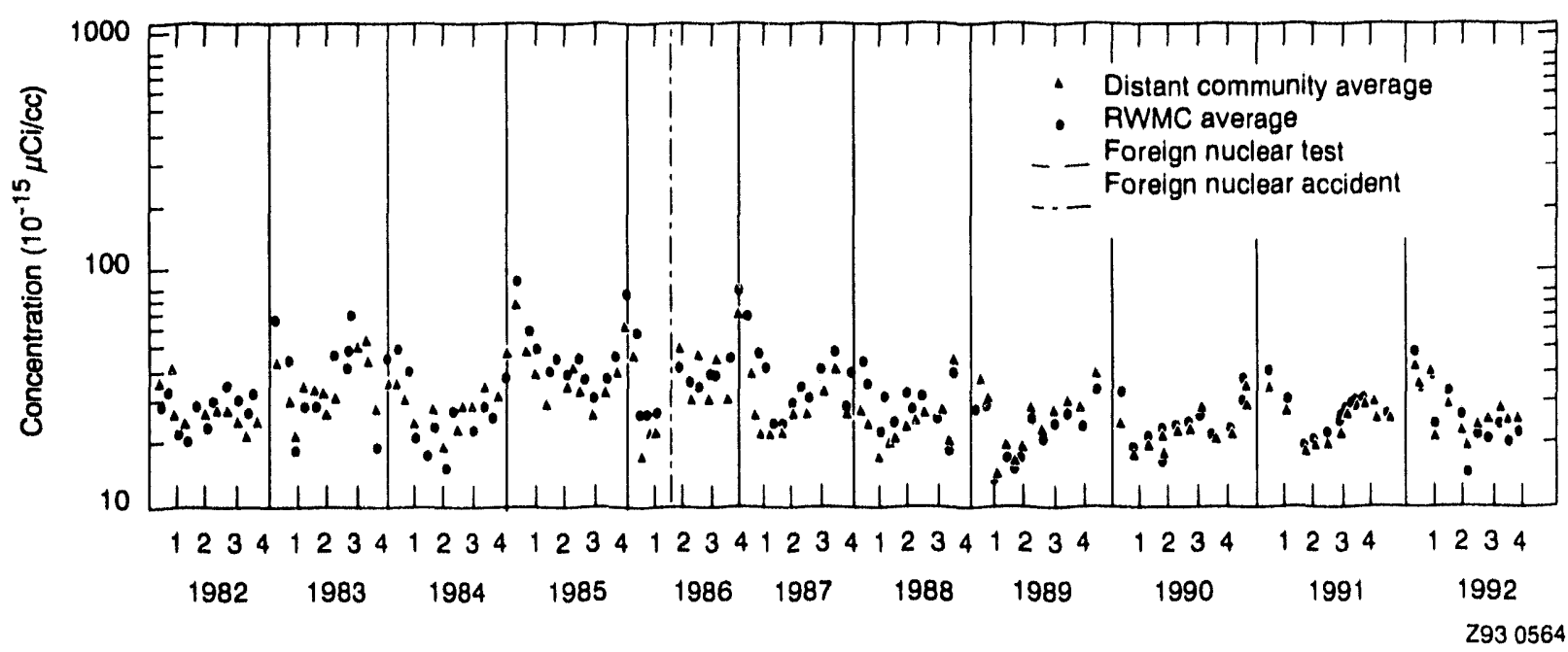

Figure 20. RESL monthly average gross beta concentrations (LV air samplers).

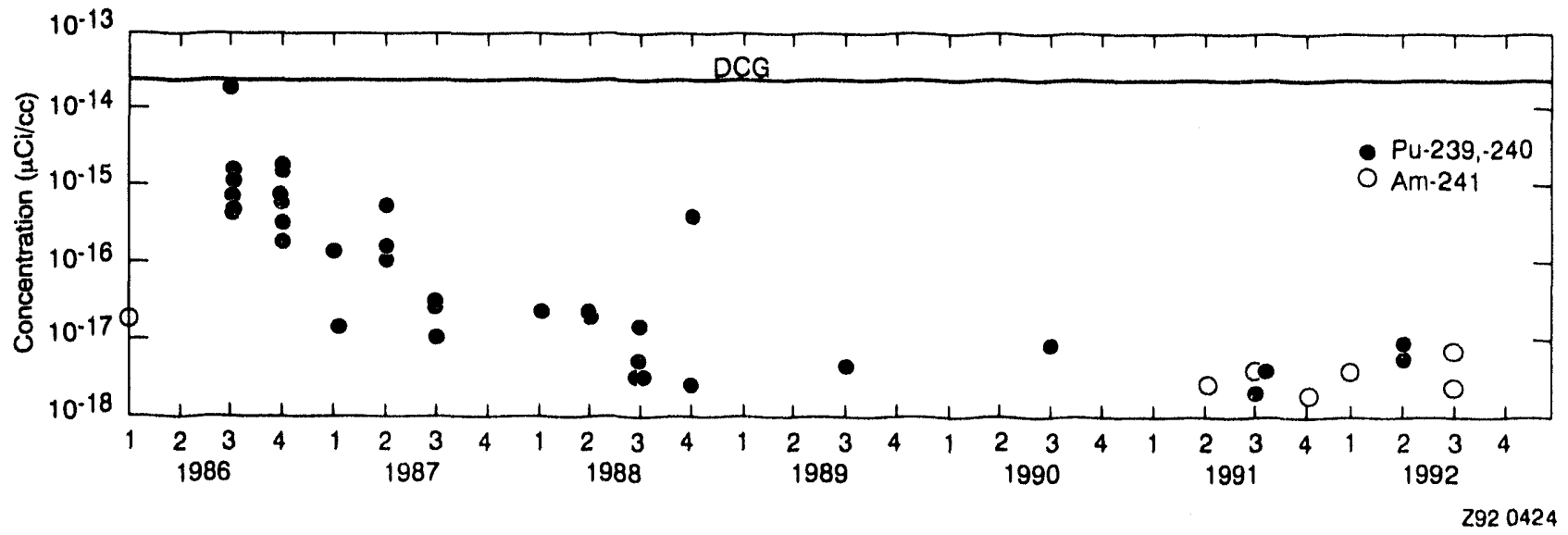

Figure 21. Am-241 and Pu-239,-240 quarterly composite concentrations for air filters at RWMC locations. The derived concentration guide per DOE Order 5400.5 for Am-241 and Pu-239,-240 is $2.0 \times 10^{-14} \mu \mathrm{Ci} / \mathrm{mL}$. 


\section{Waste Experimental Reduction Facility}

The air-monitoring locations around the WERF are shown in Figure 10 and the control location is shown in Figure 11. The quarterly average of gross beta activity for the WERF is shown graphically in Figure 22. The unusually high gross beta results observed in 1986 were attributed to the Chernobyl accident.

Figure 23 shows the maximum gross beta activity concentrations, and mean gross beta activity at the WERF for each semimonthly period. Monthly mean concentrations were not statistically different from those reported for the control location.
During 1992, there were no detections above background of gamma-emitting radionuclides in WERF monthly air sample composites. Since no known source of TRU radionuclides exists in this area, no specific alpha and beta analyses were performed.

\section{Mixed Waste Storage Facility}

Figure 10 shows the location of the air monitor at the MWSF. This monitor was installed in October 1986. No airborne gross alpha or beta concentrations above ambient levels were detected (see Figure 24). No man made gamma-emitting radionuclides were detected at the MWSF during 1992. Since there is no known source of TRU radionuclides in this area, no specific alpha and beta analyses were performed.

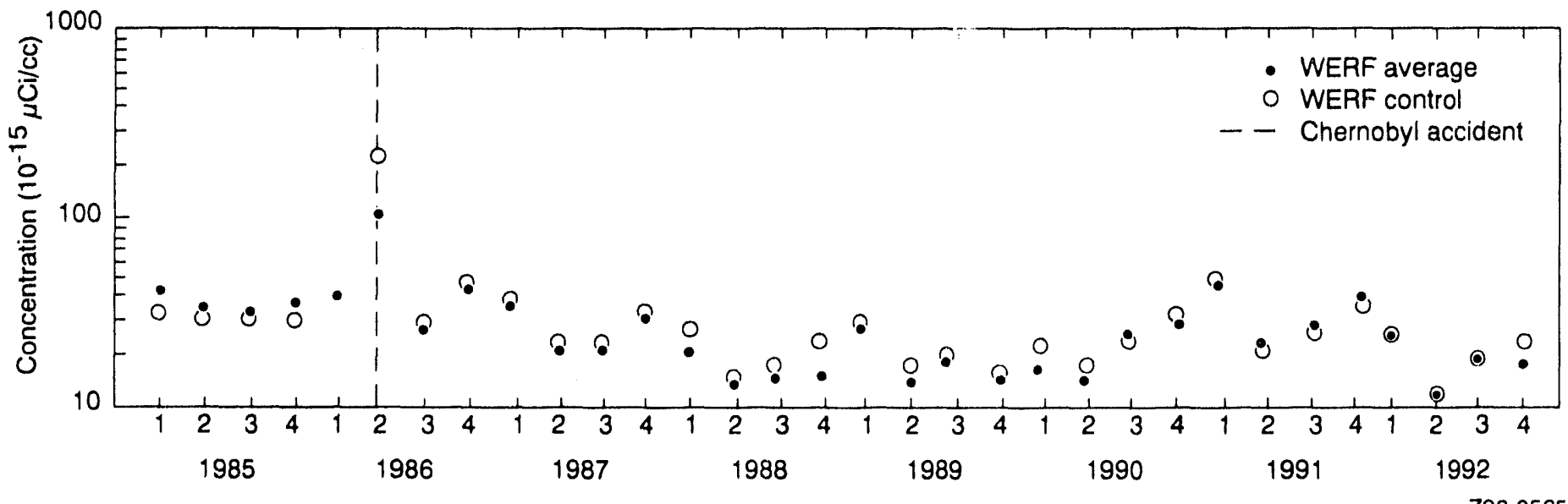

Figure 22. Quarterly average of gross beta air concentrations rneasured at WERF. 


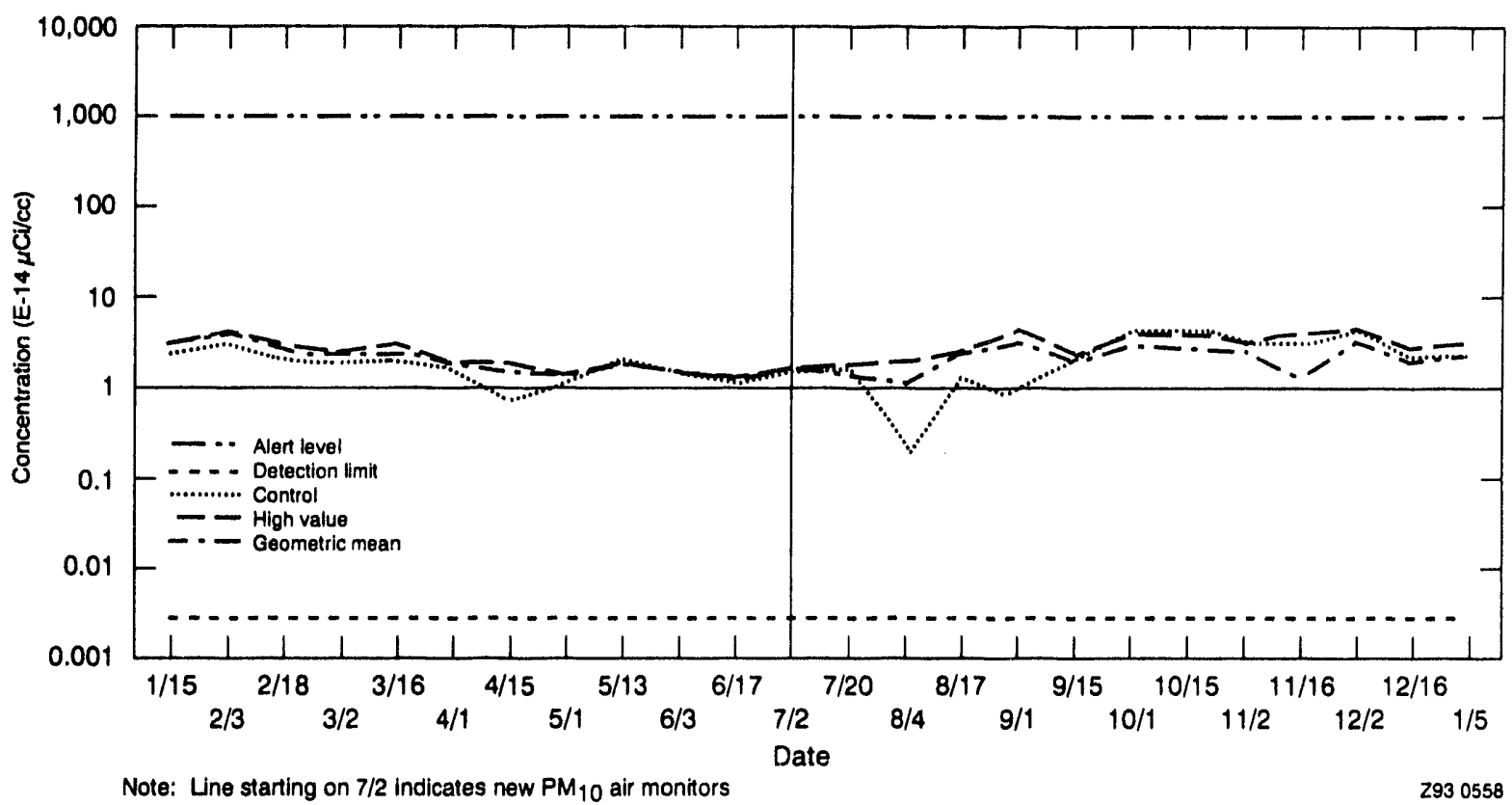

Figure 23. Maximum gross beta concentrations (Cs-137 equivalent) for WERF air filters during each semimonthly period of 1992 .

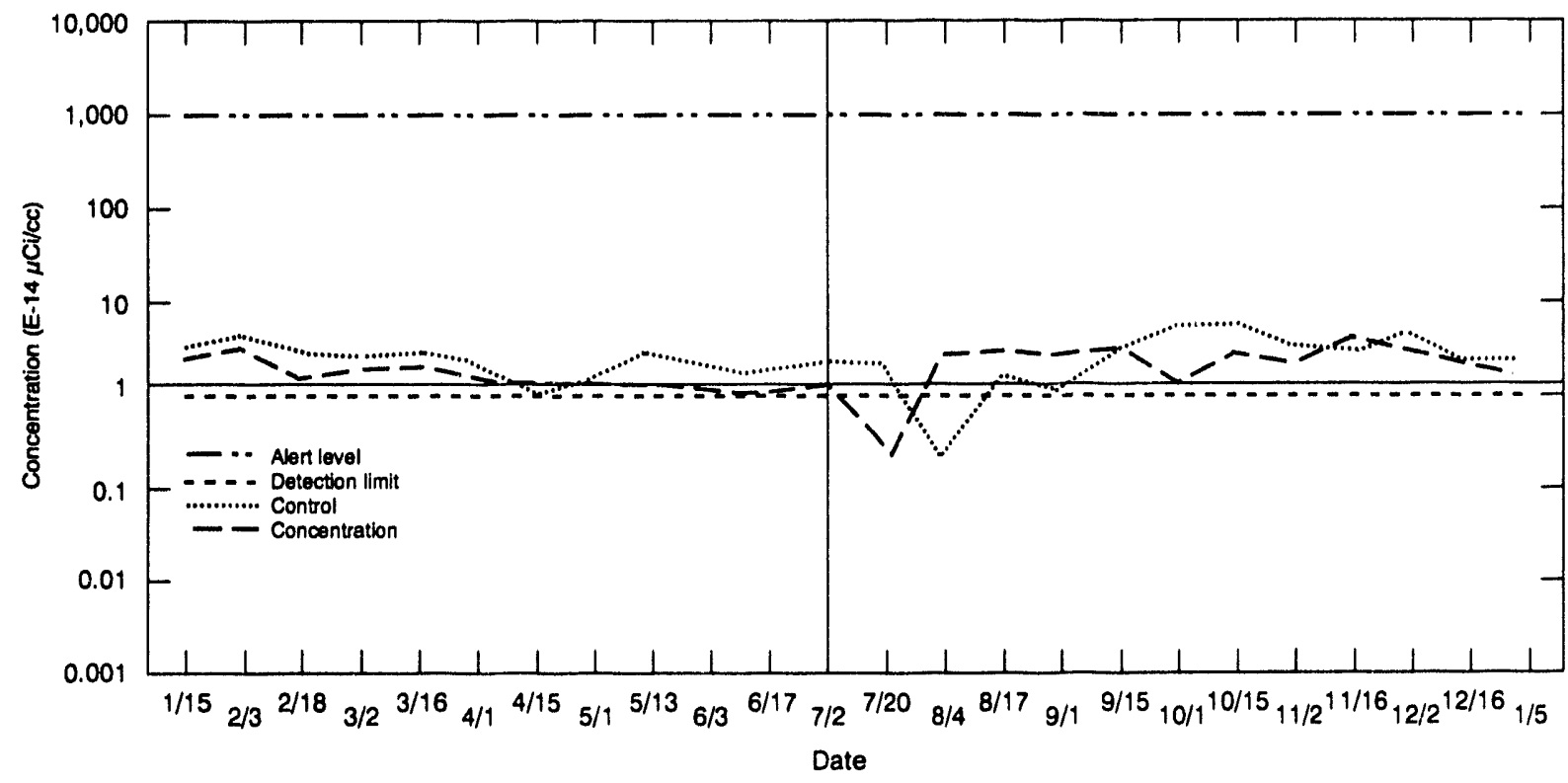

Figure 24. Maximum gross beta concentrations (Cs-137 equivalent) for SWEPP air filters during each semimonthly period of 1992. 


\section{Surface Water Run-off}

In addition to the general RESP objectives, the specific objectives of the surface water sampling activity are to: (a) determine concentrations of radionuclides in any surface waters leaving EG\&G Idaho Waste Management facilities, (b) report comparisons of measured concentrations against reference levels based on DCGs for the public given in DOE Order 5400.5, and (c) detect and report significant trends in measured concentrations of radionuclides in surface waters leaving EG\&G Idaho Waste Management facilities.

Radionuclides could be transported outside the boundaries of the RWMC via surface water runoff. Surface water run-off occurs at the SDA only during periods of snowmelt or heavy precipitation. At these times, water is pumped out of the SDA into a drainage canal. Water also runs off the asphalt pads around TSA, into drainage culverts and the drainage canal, which directs the flow outside the RWMC. The canal also carries outside run-off that has been diverted around the RWMC. Ponding of the run-off in a few low areas may increase subsurface saturation, enhancing subsurface migration.

Water samples are collected during each quarter during which sufficient rain falls or snow melts to produce run-off water from the TSA asphalt pads and in the SDA gate ditch. One sample is collected from each of the four culverts that drain off TSA asphalt pads. These four sampling points are upstream from a drainage ditch. In addition, a sample is taken at the point of discharge from the SDA near the sump pump.

Each sample was collected in a 4-L (1-gal) polyethylene container, preserved with acid, added filter paper pulp tablets, sealed, dated, and identified by location. The Radiation Measurements Laboratory (RML) analyzed the samples by means of gamma spectrometry. Gamma spectrometry was performed on both liquid and particulate fractions. Detection limits for specific radionuclides, including those most likely to be found at the RWMC, are listed in Tables B-1, B-2, and B-4 of Appendix B. The statistical approach used to analyze and interpret the data is discussed in Appendix C.

Figure 25 shows the collection of a surface water run-off sample at the RWMC. Figure 26 shows sample collection locations, including the four TSA culverts (TSA-1, TSA-2, TSA-3, and TSA-4) and the SDA pump.

Surface water run-off draining from the SDA is pumped into the SDA/TSA drainage ditch. Sampling at this point allows a direct assessment of radionuclide migration from the SDA via surface water run-off. Sampling at the TSA-1, TSA-2, TSA-3, and TSA-4 culverts (see Figure 26) allows similar assessments of these areas. Control samples are collected to determine background concentrations of the radionuclides of interest in locations unaffected by facility operations. Prior to 1984 , the control sample location was changed from the Big Lost River, which was not considered to be representative of background surface water run-off at the RWMC, to a ponding area 1.2 miles north of the RWMC (T-12 Road). This control location is currently being used with samples collected at the SDA and a new control location was established at the rest area on Highway 20 for samples collected at the TSA Pad.

Surface water run-off samples were only collected during the first and second quarters due to the availability of run-off waters. No gammaemitting radionuclides were detected at concentrations above ambient concentrations during 1992.

Water run-off samples were also submitted and were analyzed for specific alpha- and betaemitting radionuclides. Am-24l was detected at the TSA-4 location. This concentration was $(1.2 \pm 0.2) \mathrm{E}-10 \mu \mathrm{Ci} / \mathrm{mL}$ and represents $0.04 \%$ of the DCG in water. Comparable concentrations of Am-241 have been noted at the RWMC in the past. These concentrations are near the detection limits and are comparable to concentrations noted at distant community locations. 


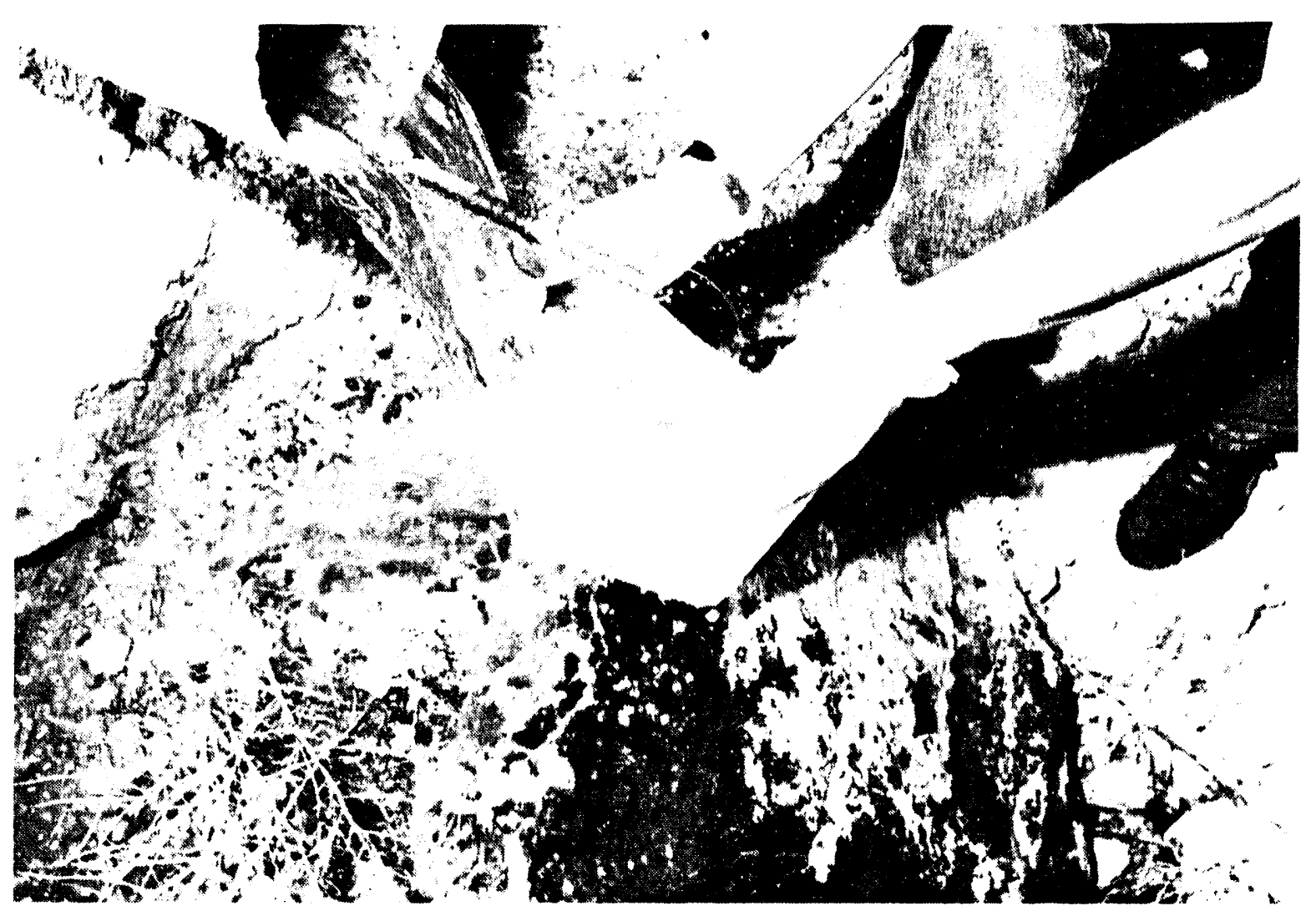

Figure 25. RW'MC surface water run off collectom.

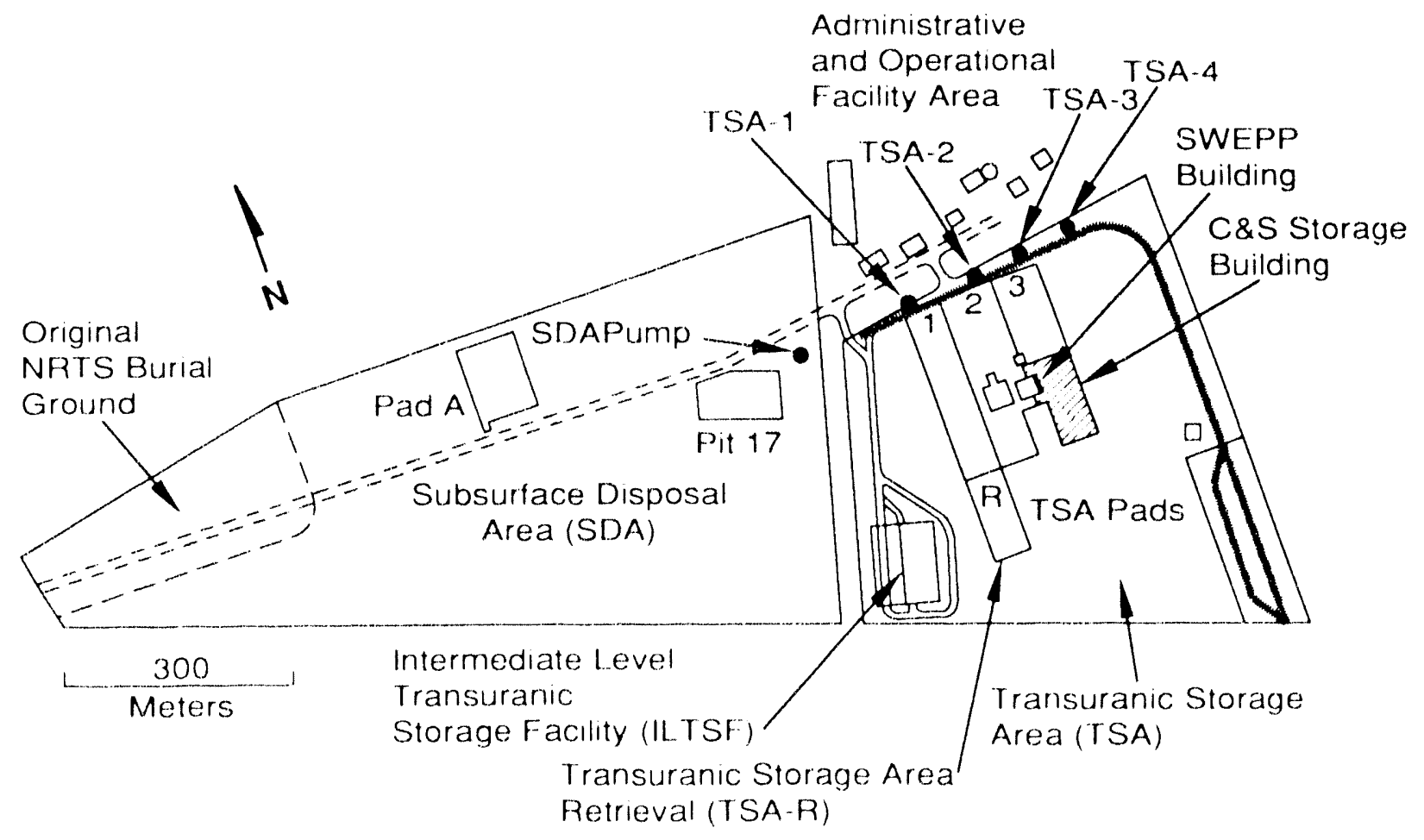

- Current water sampling locations

B930039

Figure 26. Simpling locatrons for surface water run off 
Generally, most concentrations of radionuclides detected in surface water at the RWMC were at or near environmental levels. Each detection found above background level was at a small fraction of the applicable DCG. DOE facilities generally compare results from permanent surface waters (i.e., rivers, lakes, and springs) with DCGs. The DCGs are used as a point of reference only. Comparison of individual measurements to the DCGs gives the maximum dose a person could receive at the location where the sample was collected, given the following two assumptions: (a) the concentration was at the DCG level continuously for the entire year, and (b) the person receiving the exposure was at that location for the entire year, continually drinking the water or inhaling the air. This is a very conservative approach and is used only as an alert measure as those values are collected on-Site and not at the receptor of the maximally exposed individual.

\section{Soils}

In addition to the general RESP objectives, the specific objectives of the surface soil sampling activity are to: (a) determine concentrations of radionuclides in soils in the vicinity of EG\&G Idaho Waste Management facilities and (b) detect and report significant trends in measured concentrations of radionuclides in soils.

At each sampling station, a soil sample is collected at each of the four corners and at the center of a $10 \times 10-\mathrm{m}(33 \times 33-\mathrm{ft})$ square. The samples are then combined to form one composite sample. A stainless-steel sampling ring is used to collect a $12-\mathrm{cm}$ diameter $\times 5-\mathrm{cm}$ deep sample from these soils (see Figure 27).

The samples are dried, weighed, homogenized (ball-milled), screened through a number 35 sieve, and then analyzed by gamma spectrometry and radiochemistry. Specific radionuclides that are most likely to be found, and their detection limits, are listed in Tables B-1 and B-2 of Appendix B.

\section{Radloactive Waste Management Complex}

Surface and near-surface soils at the RWMC have become contaminated from past flooding of open pits, waste handling, and biotic intrusion.
Of particular concern are measured concentrations of Pu-239,-240 and Am-241, from past flooding, in surface soils in and outside the northeast comer of the SDA. ${ }^{7}$ Wind, water, and biota can transport contaminated soil particulates onand off-Site.

The 1983 MAR provides much of the basis for the current surface soil sampling design. ${ }^{13}$ The MAR recommendations were implemented in 1984. The major design modification was implemented from the 1983 MAR which called for randomly selected sampling locations to five permanent plots in five major areas of the RWMC, as indicated by the types of waste buried, current operational activities, and past flooding. Those major areas are the TSA, Pad A, previously flooded areas, inactive areas, and active areas (see Figure 28).

Significant changes to the soil sampling activity were recommended hy the 1988 MAR committee. ${ }^{14}$ The major proposed revision was to eliminate routine soil sampling and replace it with special studies on an as-needed basis. The rationale for this recommendation is twofold: 1) the number of samples collected are probably insufficient for valid data interpretation; and 2) the addition of new cover soil during recontouring of the SDA in 1986 invalidates comparison with past data. The new cover soil was brought in from the lakebed at the spreading area south of the RWMC. As a result, surface soils at the RWMC were not representative of soils in the surrounding areas; therefore, RESP began collecting data on the new soil cover on a triennial basis to establish a baseline of the new soils. This effort began in 1991 at RWMC and in 1992 at SWEPP. The need for routine soil sampling will be evaluated after two sample sets have been collected.

Baseline samples were collected within the SWEPP area during 1992 (see Figure 29). The only gamma-emitting radionuclide detected in the soils was Cs-137. The maximum Cs-137 concentration was $1.20 \pm 0.04 \mathrm{pCi} / \mathrm{g}$ and was collected from location 1 . This concentration is consistent with C.s-137 levels found in undisturbed areas in and around the INEL. Concentrations at this level are attributable to fallout and are not as a result of INEL operations. 


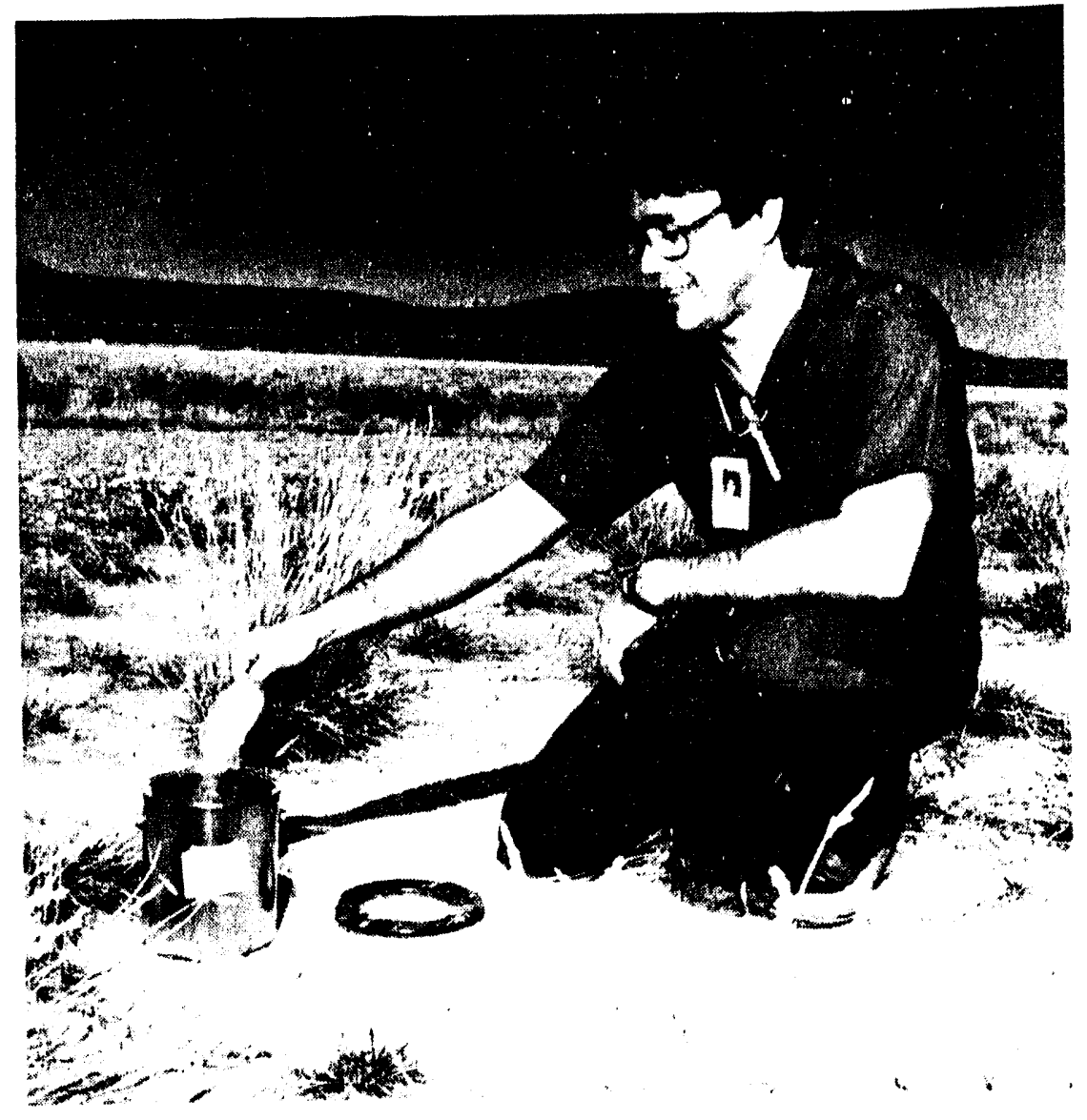

Figure 27. Soil sample collection.
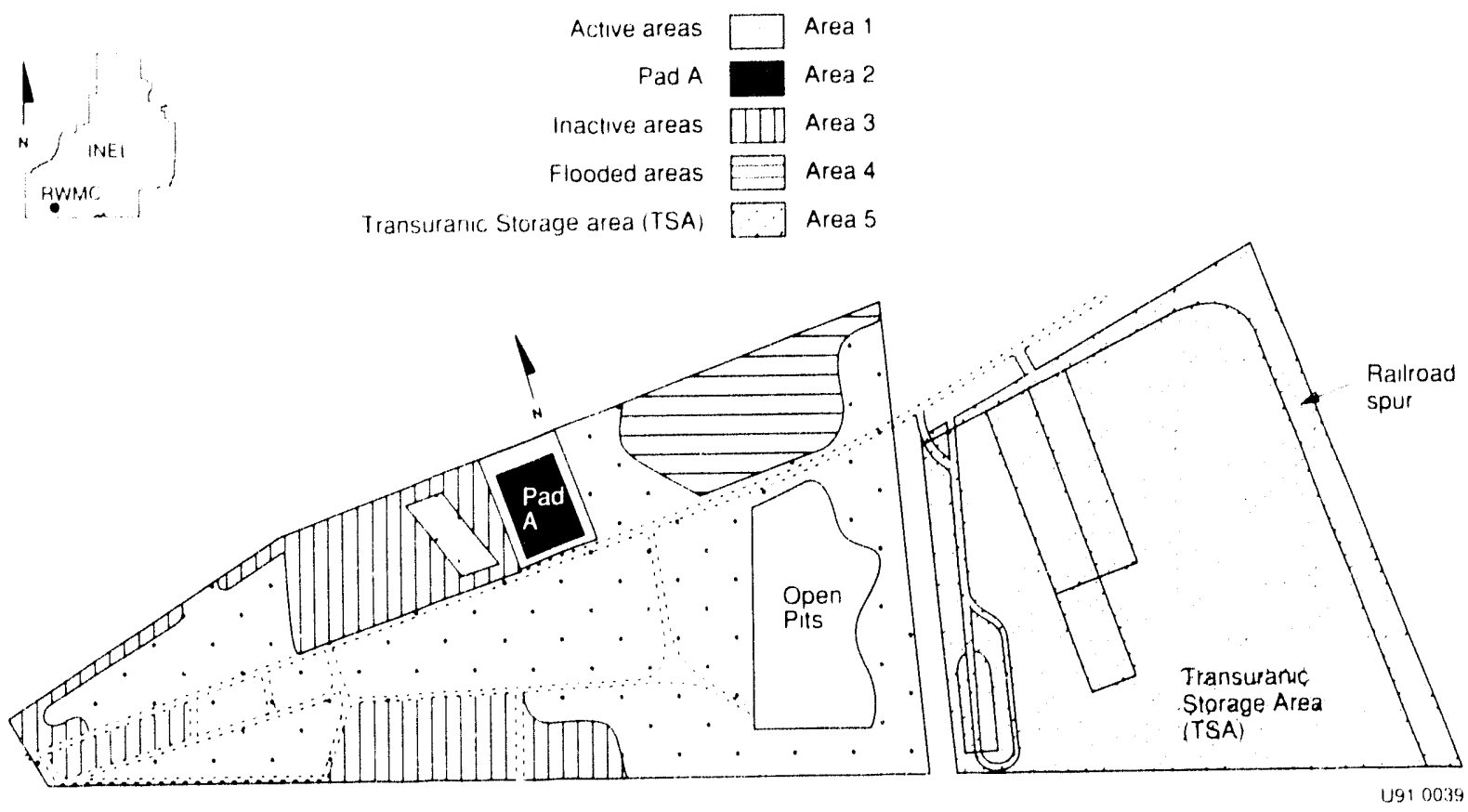

Figure 28. Five major areas of the RWMC used for vegetation, mammal, and soil collection. 


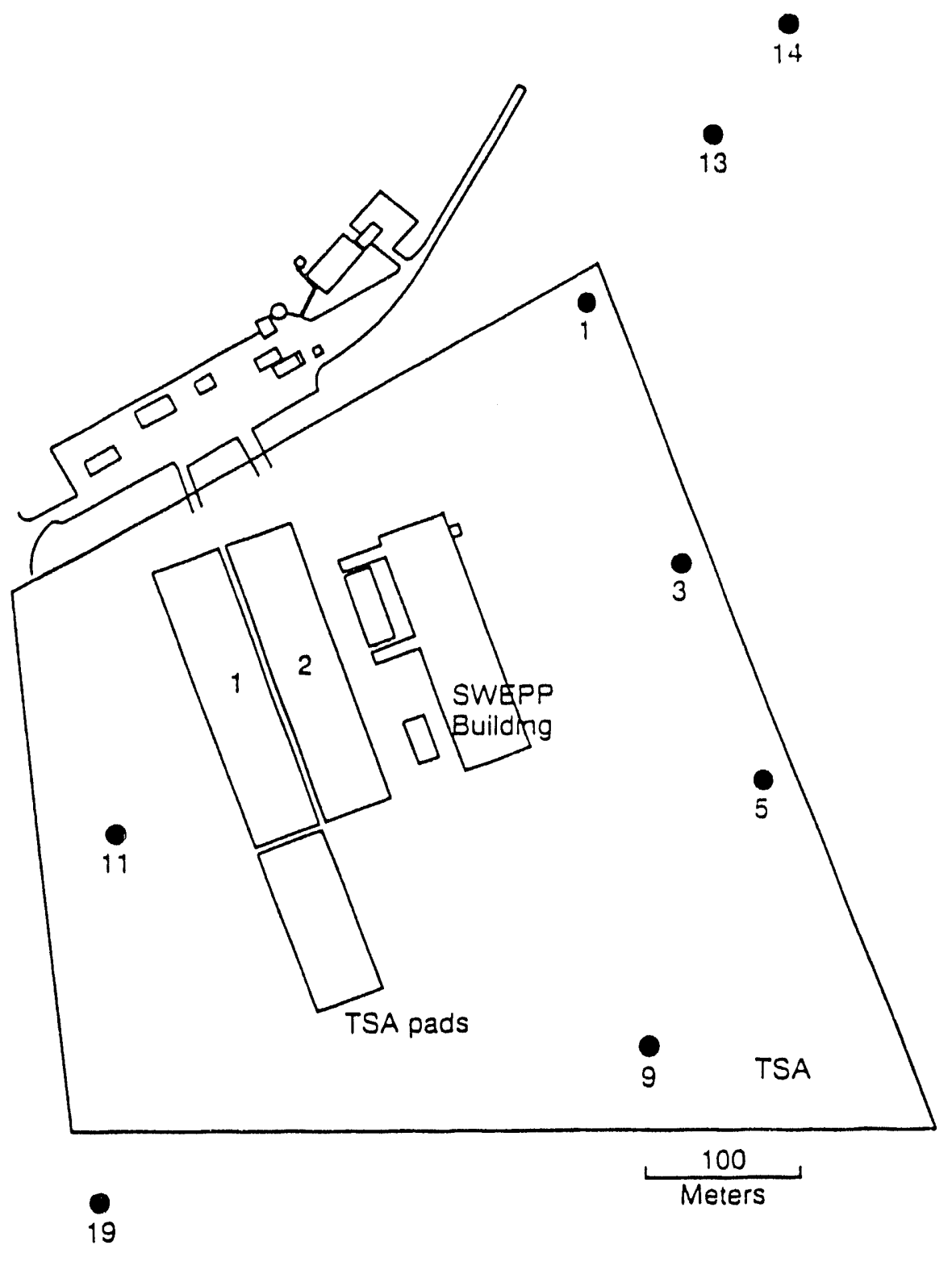

20

M92 0242

Figure 29. General SWEPP soil locations. 
The mean Cs-137 concentration for all locations at SWEPP was less than the mean concentration found at the control location.

Selected soil samples collected at SWEPP were also submitted for specific alpha- and betaemitting radionuclides. Due to circumstances beyond the control of the analytical laboratory, this data was not available in time for inclusion into this report. This data will be reviewed upon receipt and will be evaluated for inclusion in the 1993 annual report.

\section{Waste Experimental Reduction Facility}

Routine soil samples are collected triennually from the 11 locations shown in Figure 30 near WERF. Control samples are collected near the Main Gate, Building 603 (see Figure 11). The next scheduled sample collection is in the summer of 1993.

\section{Biotic Surveillance}

In addition to the general RESP objectives, the specific objectives of the routine biotic surveillance are to: (a) determine if biota are transporting radionuclides from buried waste or contaminated soil, (b) identify biotic conditions which may compromise waste confinement at waste storage and disposal facilities, and (c) detect and report significant trends in the radionuclide and concentrations in biotic samples.

Plants and animals are potential pathways for migration of radionuclides away from the facility. Uptake of radionuclides by vegetation at the RWMC has also been documented by RESL. ${ }^{15}$

Routine biotic monitoring was not conducted prior to 1983 . Some preliminary data on radionuclide concentrations in deer mice and crested wheatgrass were collected by EG\&G Idaho during fiscal year 1982. Visual biotic inspections began in April 1983.
A detailed long-range plan for biotic monitoring, including procedures for routine monitoring, was completed in the fall of 1983.16 The sampling design involved sampling at the five major areas designated for soil sampling.

\section{Vegetation}

Three subsamples are collected from each of the sampling locations and combined into one composite sample. The method of collection and species alternates each year. Crested wheatgrass is collected in odd-numbered years and is clipped at ground level within a $1 \times 1-\mathrm{m}(3.3 \times 3.3-\mathrm{ft})$ frame. Russian thistle is collected in even-numbered years, and the entire plant is pulled up within a $1 \times 1-\mathrm{m}$ frame (see Figure 31 ). Either rabbitbrush or sagebrush is collected in oddnumbered years by clipping $20 \%$ of the branches from the designated plants. Thus, the same plant can be sampled biennially.

The samples are oven dried, milled, and weighed before they are submitted to the RML for gamma spectrometry analyses. After gamma analyses, selected samples are submitted to the Bioassay Group (BAG) for specific alpha and beta analyses.

Prior to 1990 , the only samples submitted for specific radiochemical analysis was the sample with the highest Am-241 concentration as identified by gamma spectroscopy. If Am-241 was not detected, then one sample from the previously flooded area was submitted. RESP identified the lack of available data for making comparison to past data. As a result, at least one sample from each of the five major areas is submitted for specific radiochemical.

RWMC. Russian thistie was collected in 1992 from the five major areas of the RWMC (see Figure 28). Control samples were collected near Frenchmar's Cabin, located approximately $11 \mathrm{~km}(7 \mathrm{mi})$ south of the SDA at the base of the Big Southern Butte. No gamma-emitting radionuclides were detected in any of the samples from the five major areas or in the control samples. 


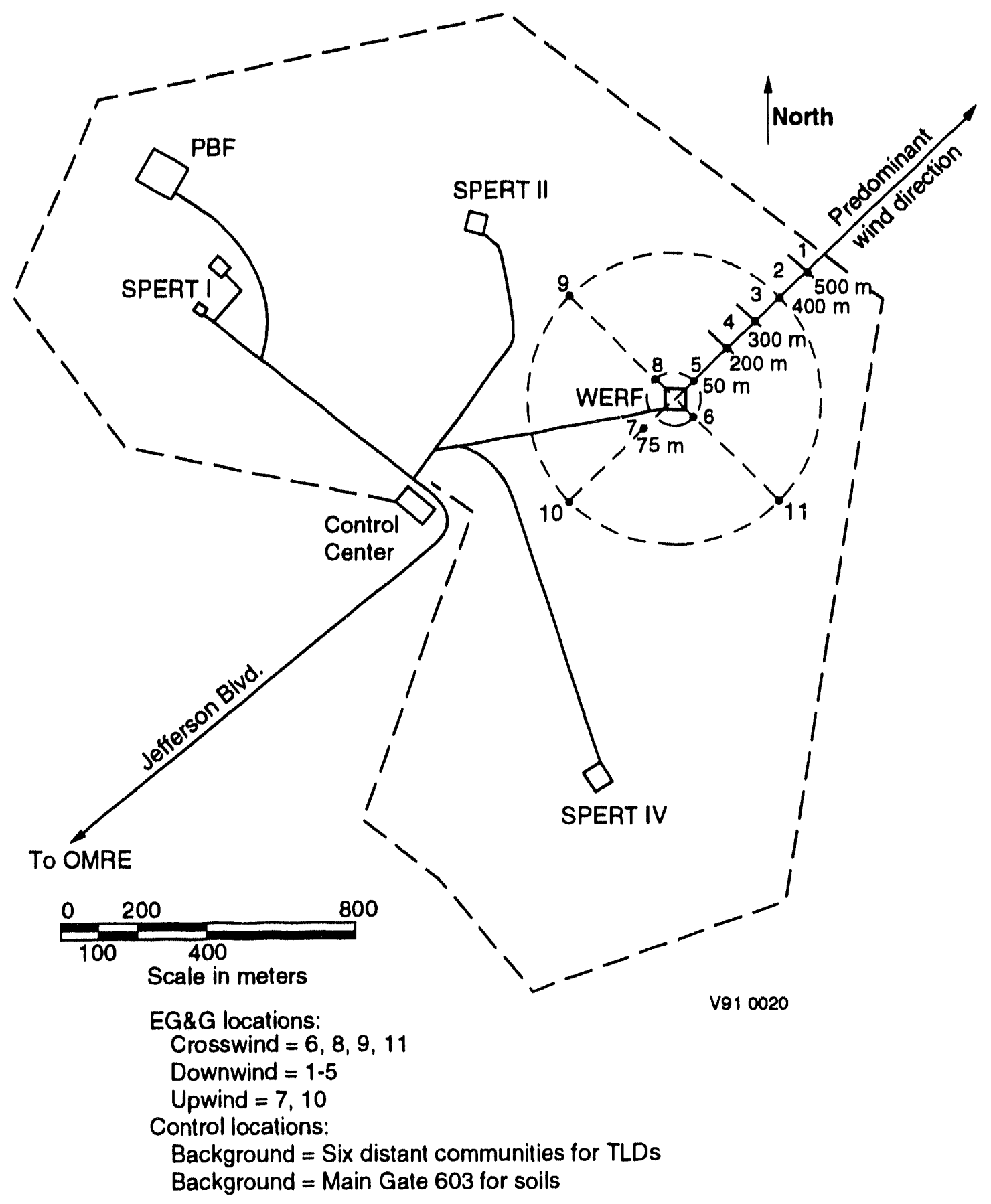

Figure 30. WERF TLD soil and vegetation locations. 


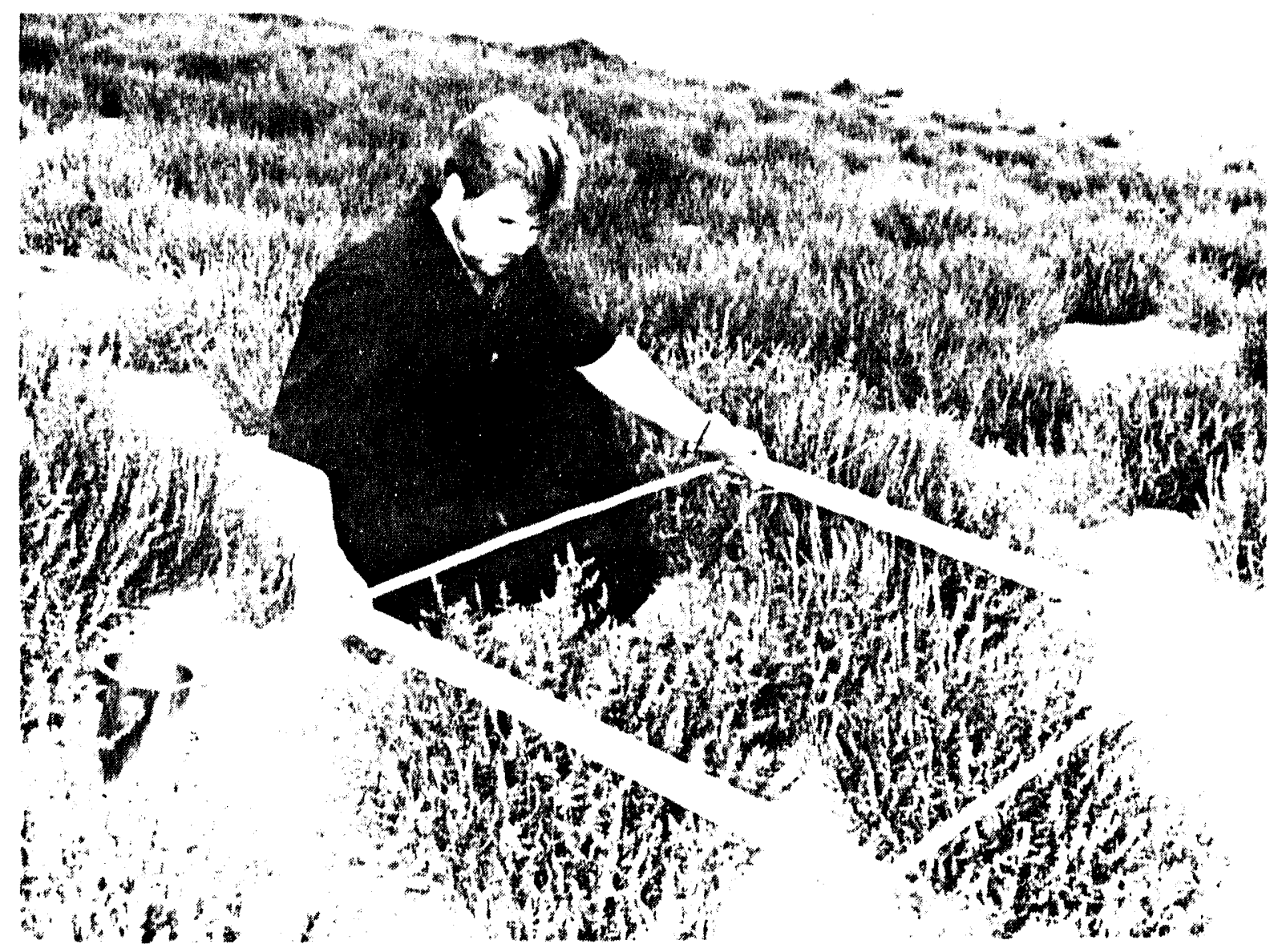

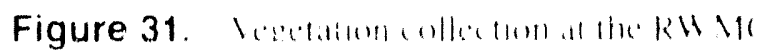

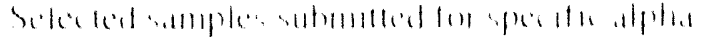

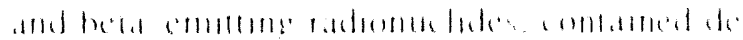
16lathe a

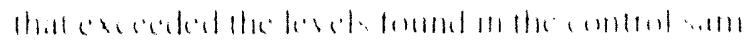

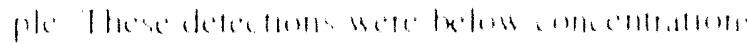

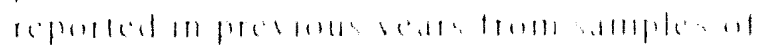

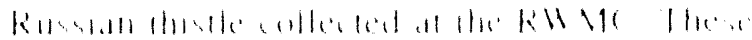

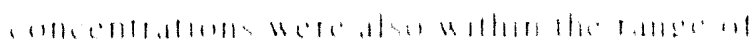

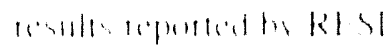

WERF I.

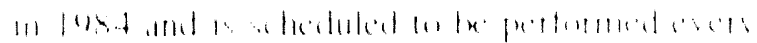

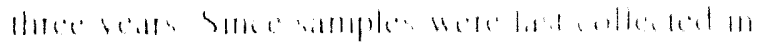

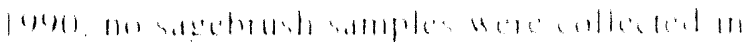

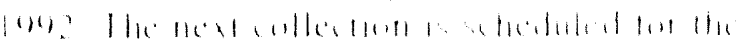

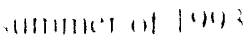

Radioactivity in Small Mammals

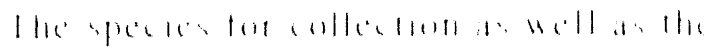

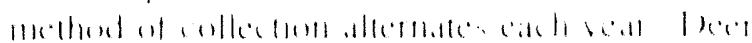

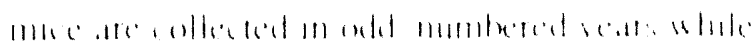

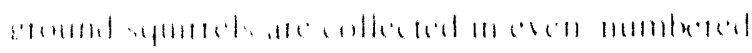

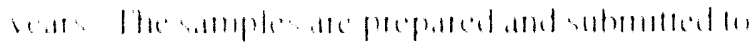

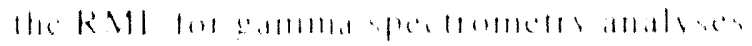

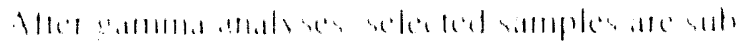

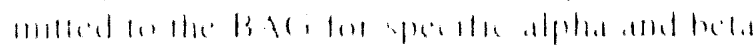
$.111,11 \times 11$

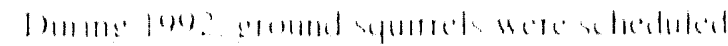

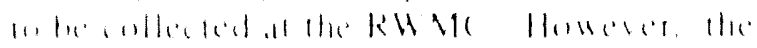

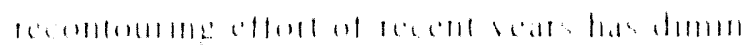

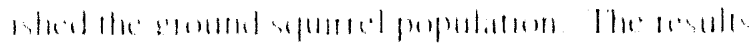

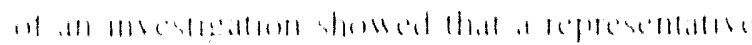

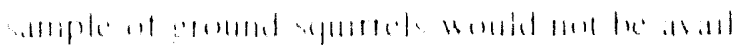

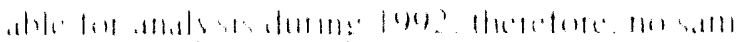

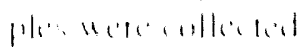

\section{Soil Excavated by Small Mammals}

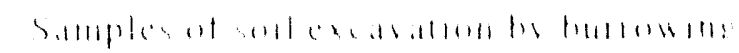

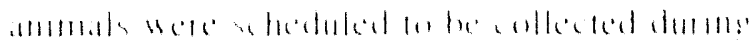

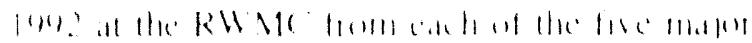

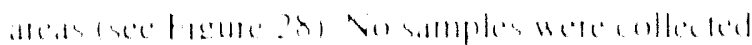

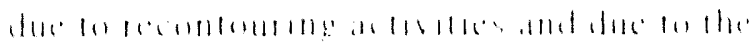


diminishing population of small mammals at the facility.

\section{Penetrating Radiation}

In addition to the general RESP objectives, the specific objectives of the penetrating radiation monitoring activity are to (a) demonstrate compliance with the limit for direct penetrating radiation established in RWMC Project Directive 6.1, Radiation and Contamination Control (1 $\mathrm{mR} / \mathrm{hr}$ at $3 \mathrm{ft}$. above ground), (b) characterize direct radiation levels at specific points of interest at EG\&G Idaho Waste Management facilities, (c) detect and report significant trends in measured levels of penetrating radiation.

TLDs are used to measure cumulative exposures to ambient ionizing radiation. Figure 32 shows the placement of a TLD.

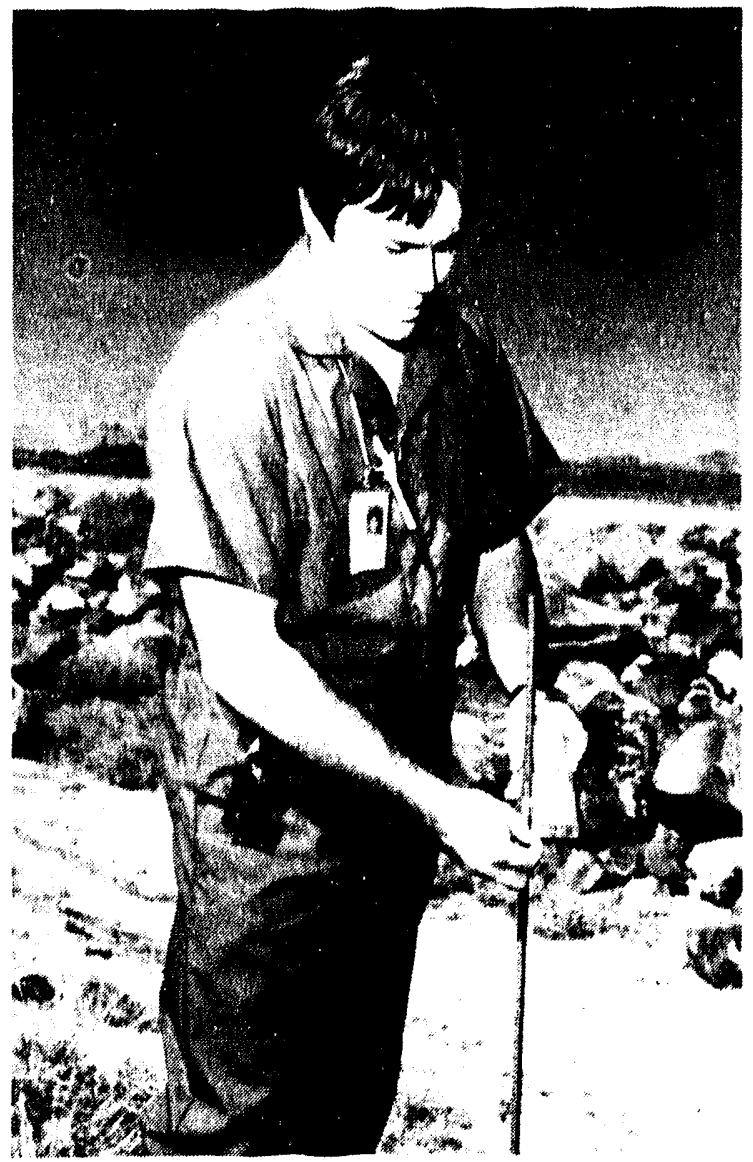

Figure 32. Placement of a TLD at a facility perimeter station.
The TLDs are sensitive to beta energies greater than $200 \mathrm{KeV}$ and to gamma energies greater than $10 \mathrm{KeV}$. The TLD packets contain five lithium fluoride chips and are located about $1 \mathrm{~m}$ $(\sim 3 \mathrm{ft})$ above the ground at specified locations. The five chips provide replicate measurements at each location. The TLD packets are replaced in May and November of each year. The sampling periods for 1992 were from November, 1991 to May, 1992, and from May to November 1992.

\section{Radloactive Waste Management Complex}

The TLD packets were placed by RESP at five locations around the RWMC and at two locations (SWEPP 1 and 5) on the TSA fence. TLD packets were placed at 25 locations by RESL. (See Figure 33 for all locations). The locations at stations $1,31,33$, and 35 were changed slightly in November 1988 and are now labeled 1B, 31 B, 33B, and 35B. RESL locations $3 A$ through $31 \mathrm{~A}$ were moved in May 1988 due to the new fence and raising of the dike around the SDA. Two additional locations, stations 46 and 47 , were added to the perimeter of the RWMC in May 1989 and thus a total of 32 locations are monitored.

Background exposure is a measurement of penetrating radiation from natural terrestrial sources (rocks and soil), cosmic radiation, fallout from testing of nuclear weapons, and local industrial processes. The background exposure consists of an average of exposures obtained from the TLDs in the seven communities on the Snake River Plain located outside the INEL boundary. Background exposures were measured at Aberdeen, Blackfoot, Craters of the Moon National Monument, Idaho Falls, Minidoka, Rexburg, and Roberts.

Stations 33B and 35B at the RWMC showed the highest exposures in both reporting periods of 1992. Locations 1, 33, and 35 have frequently shown the highest exposure. In general, the highest exposures are less than exposures from previous years. These stations measure exposures associated with the active disposal pit and operational activities at the RWMC. 


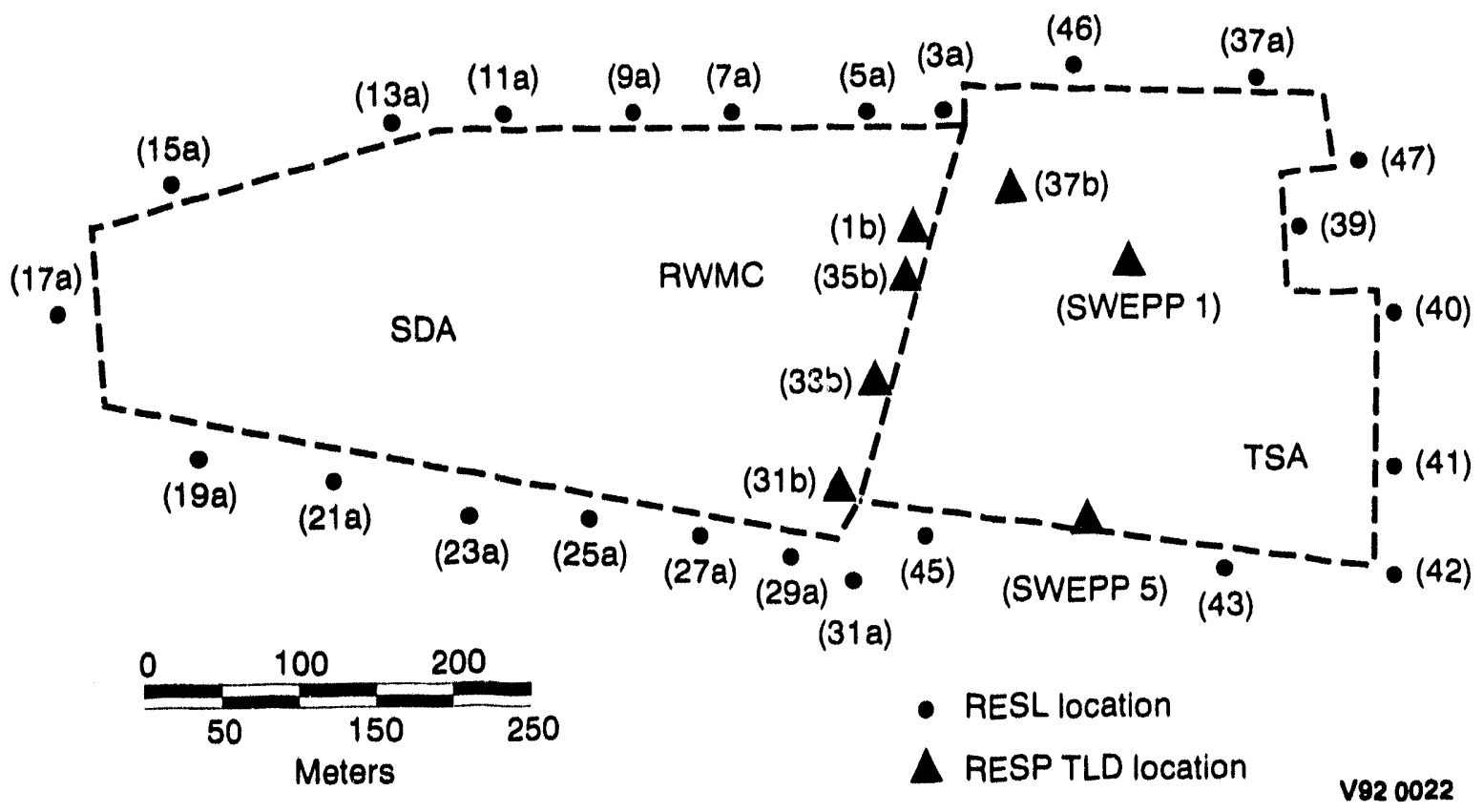

Figure 33. RWMC TLD locations.

Figures 34 through 41 show the six-month exposures for the past 10 years as measured by TLDs along the following RWMC SDA borders: northwest, northeast, south, southwest, southeast, west, and east. Average distant-community background exposure is shown on each graph for comparison.

Several general observations can be made about the data presented in Figures 34 through 41. First, there is a decreasing trend in exposures over time at most locations around the SDA, especially from 1974 through 1980 . (Refer to the 1991 Annual Report for plotted data beginning approximately in 1973.) Decreases can generally be attributed to the following: (a) changes in operational activities, (b) placement of additional soil over pits and trenches, and (c) radioactive decay of the radionuclides in waste already buried. Many exposures have decreased to near background exposures and tend to vary directly with background exposures.

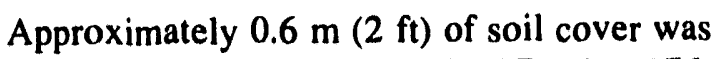
added to the northern half of the SDA in 1976. From 0.3 to $2 \mathrm{~m}$ ( 1 to $7 \mathrm{ft}$ ) of cover was added to most of the remaining portion of the SDA in the early $1980 \mathrm{~s}$. In the late $80 \mathrm{~s}$ and early $90 \mathrm{~s}$, recontouring projects have increased the soil cover over the majority of the SDA.

The second observation indicates that in past years exposures are generally lower from November through May than from May through November. Lower exposures are attributed to: (a) less handling of waste, (b) increased snow cover, and (c) increased soil moisture. This trend holds true for most years as characterized in Figure 42. Due to the drought of recent years for this area, the effects from decreased amounts of moisture and snow cover are evident by the limited variance between spring and fall exposures. 


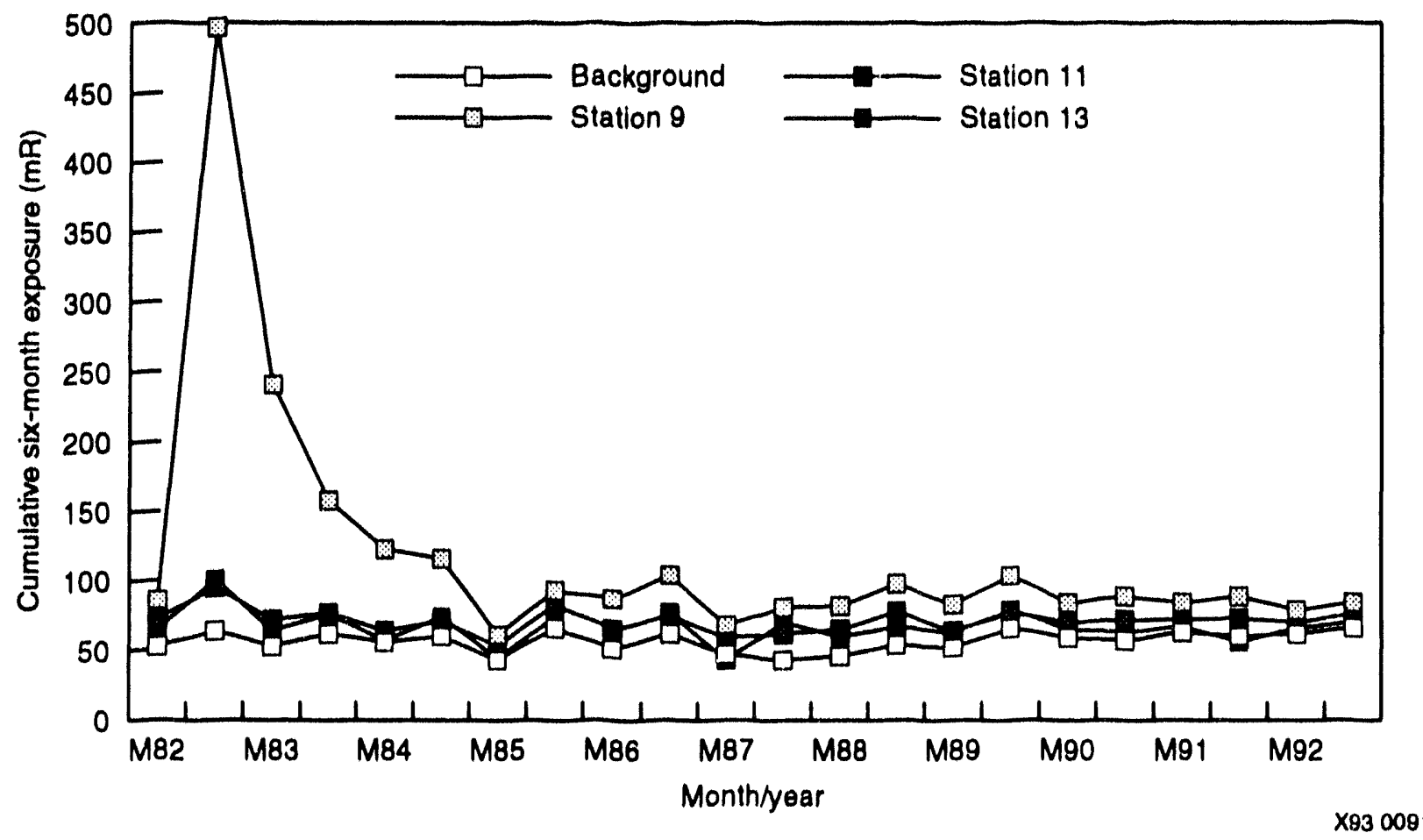

Figure 34. Six-month exposures measured by TLDs on the west end of the north border of the SDA.

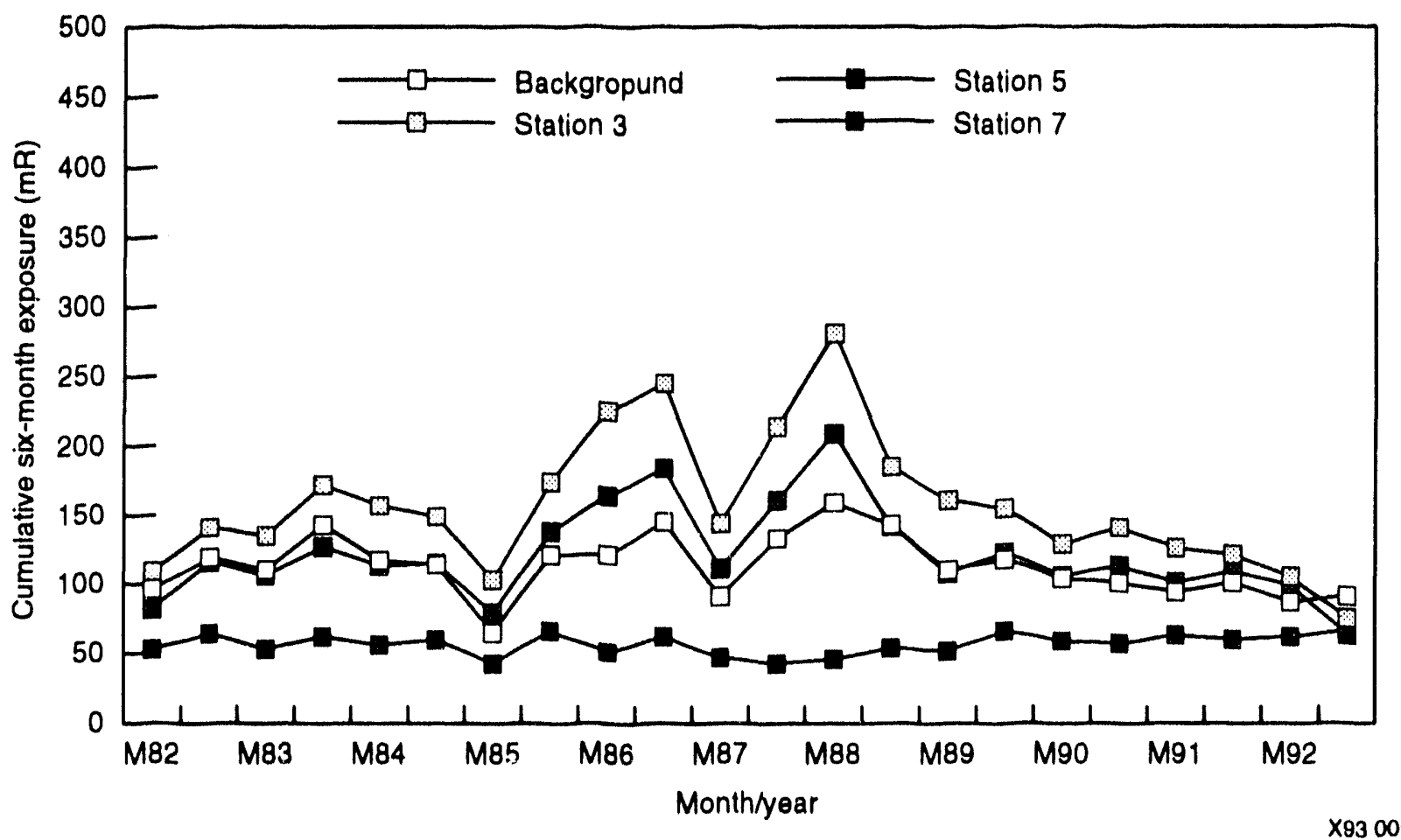

Figure 35. Six-month exposures measured by TLDs on the east end of the north border of the SDA. 


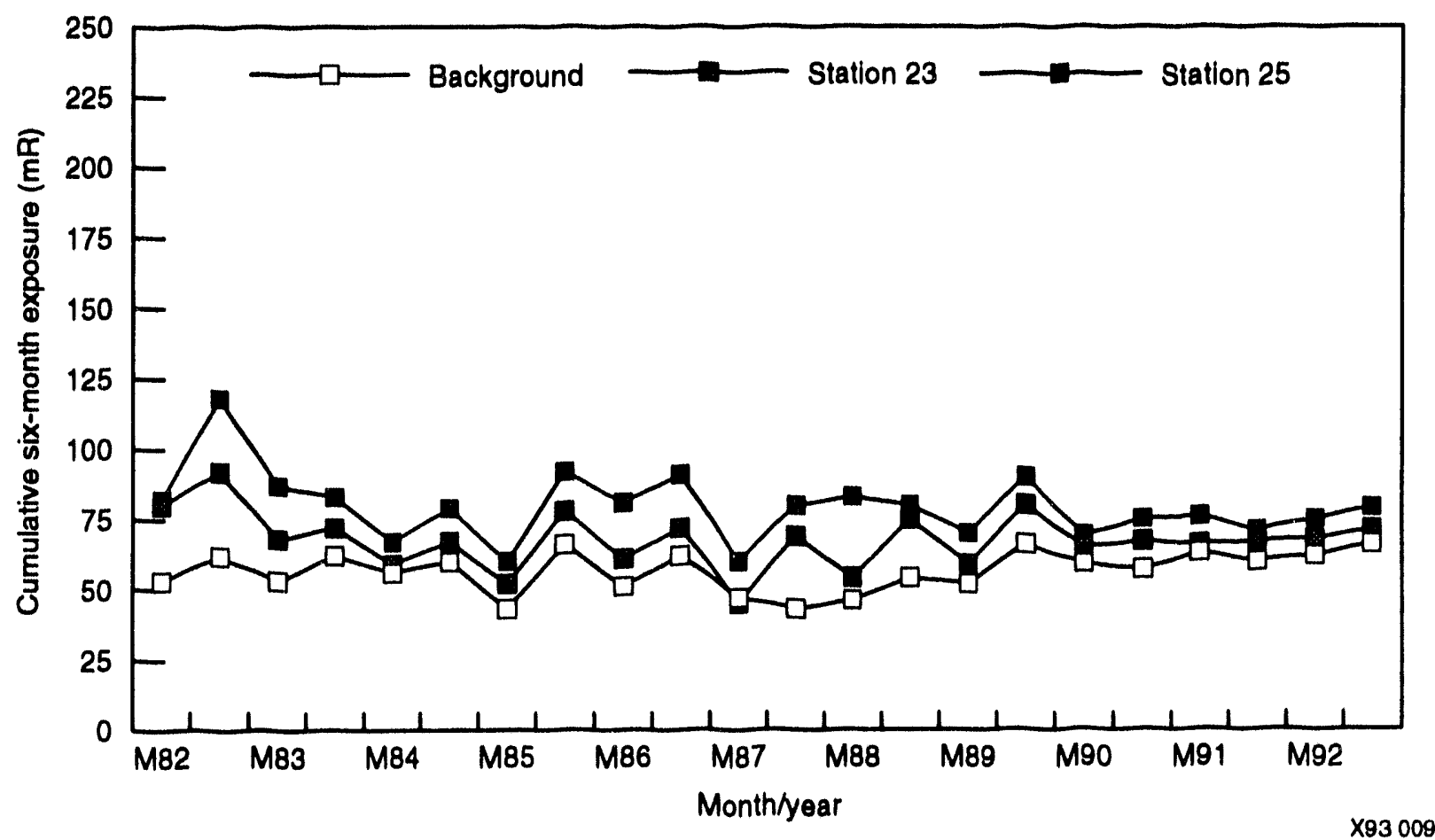

Figure 36. Six-month exposures measured by TLDs on the south border of the SDA.

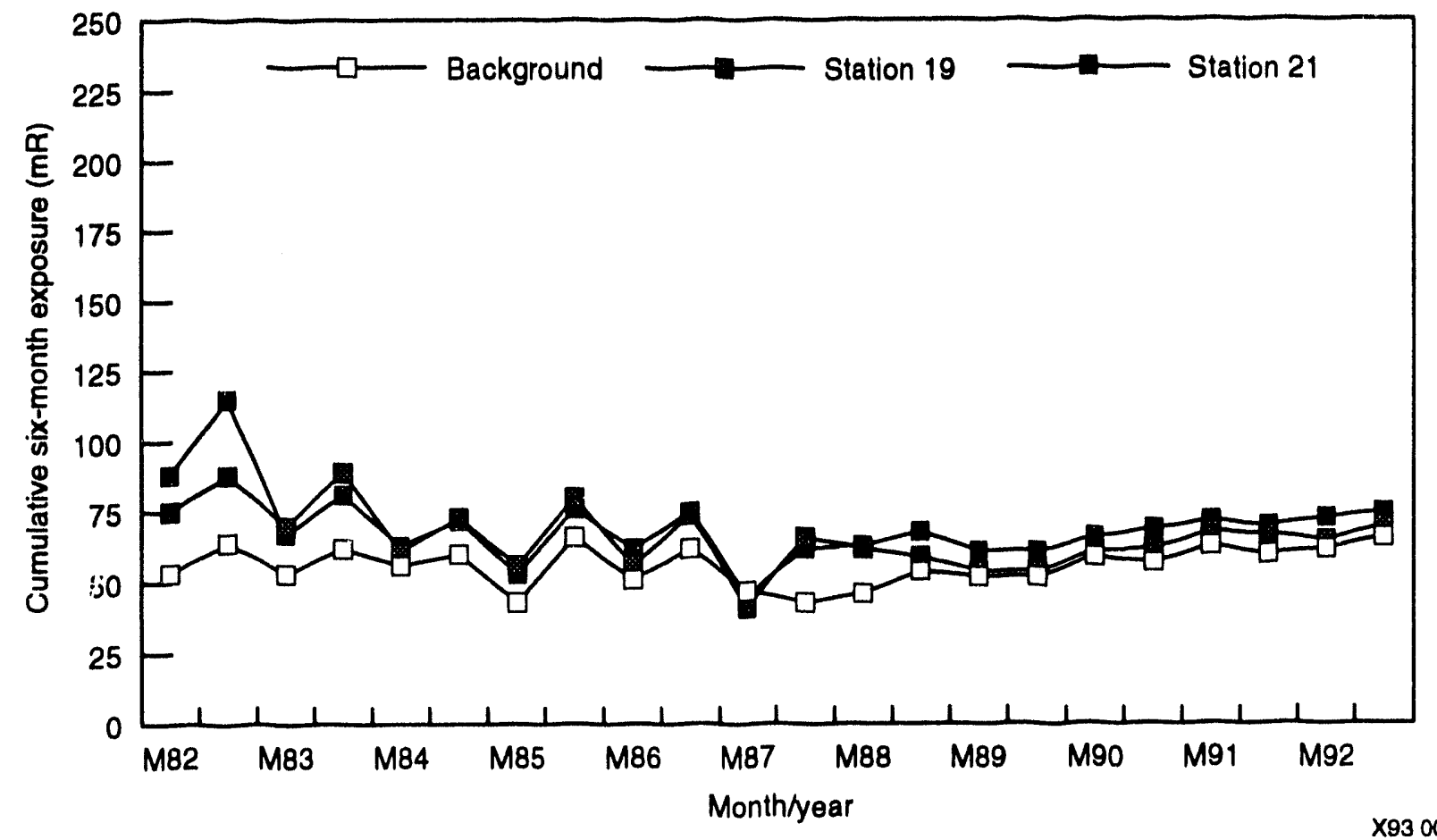

Figure 37. Six-month exposures measured by TLDs on the southwest border of the SDA. 


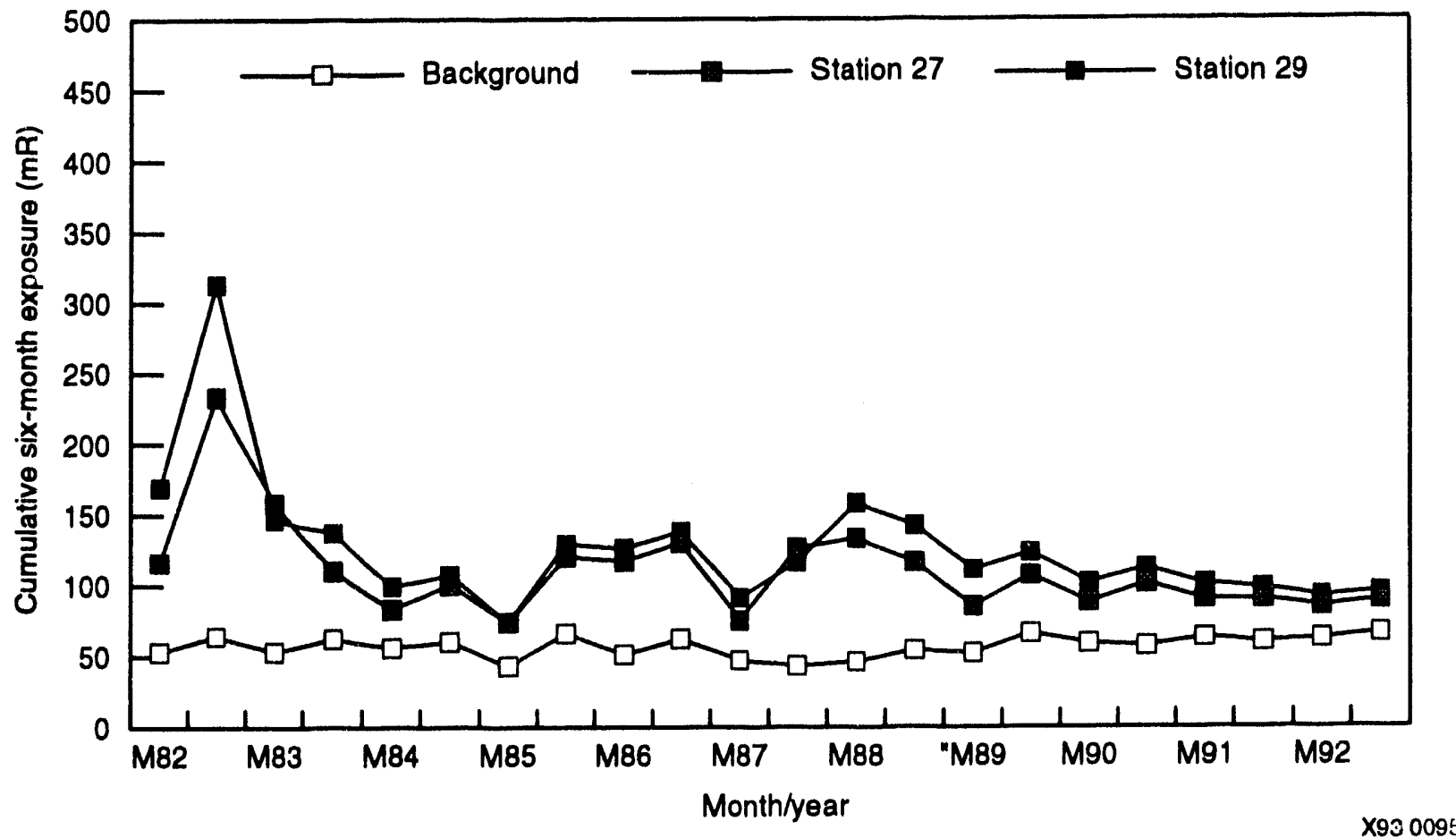

Figure 38. Six-month exposures measured by TLDs on the southeast border of the SDA.

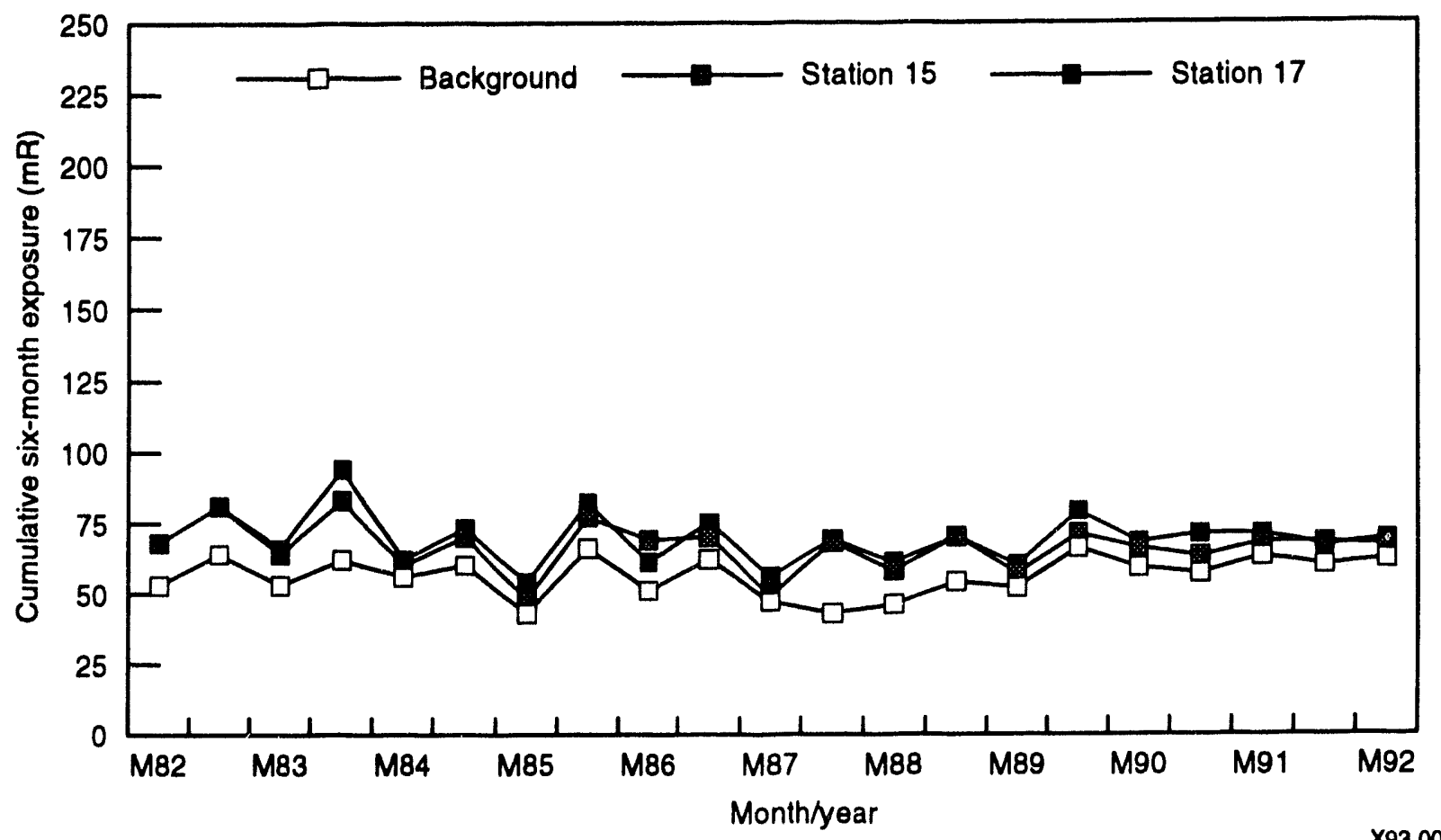

Figure 39. Six-month exposures measured by TLDs on the west border of the SDA. 


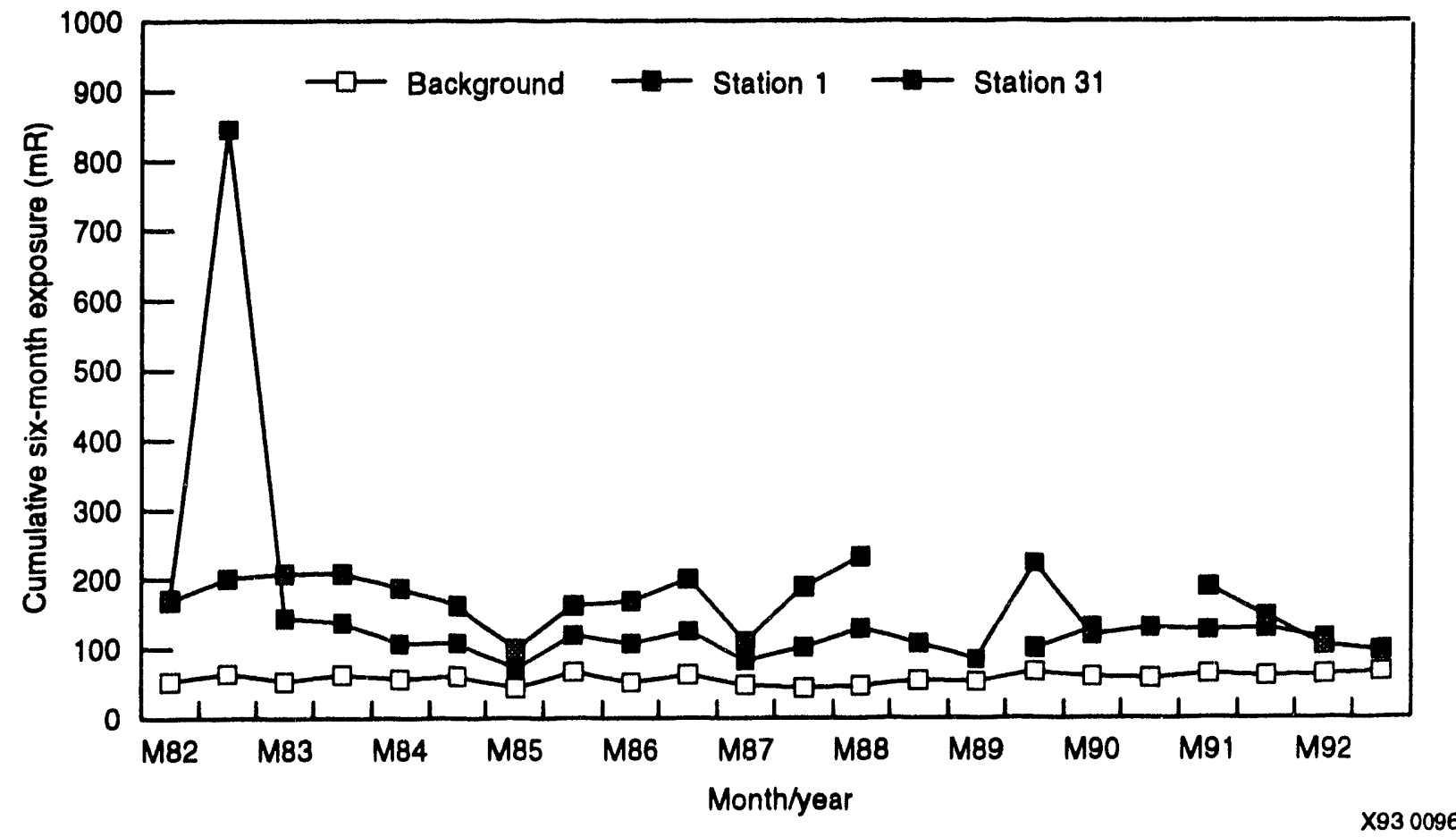

Figure 40. Six-month exposures measured by two of the four TLDs on the east border of the SDA near the active pits.

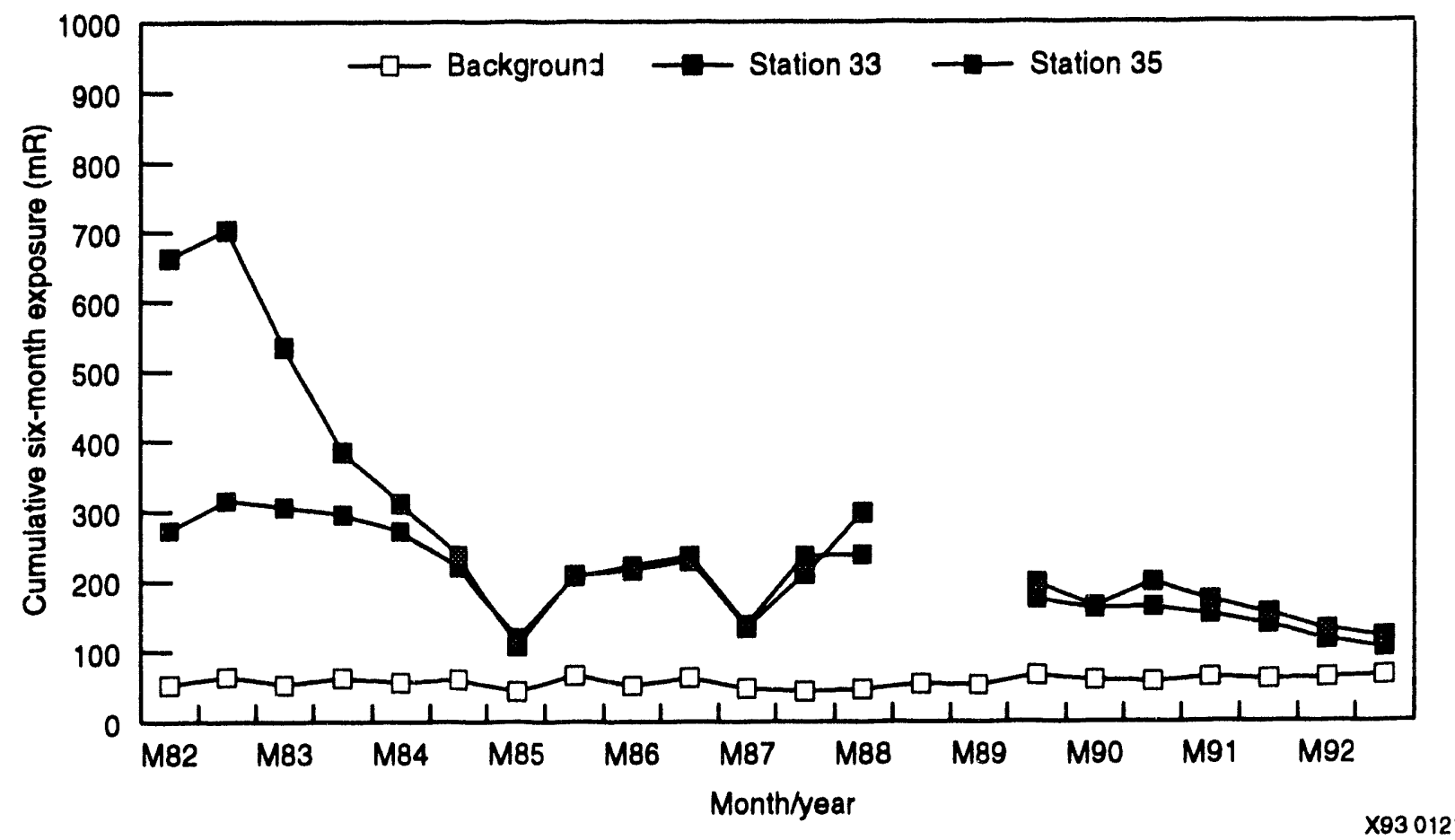

Figure 41. Six-month exposures measured by two of the four TLDs on the east border of the SDA near the active pits. 


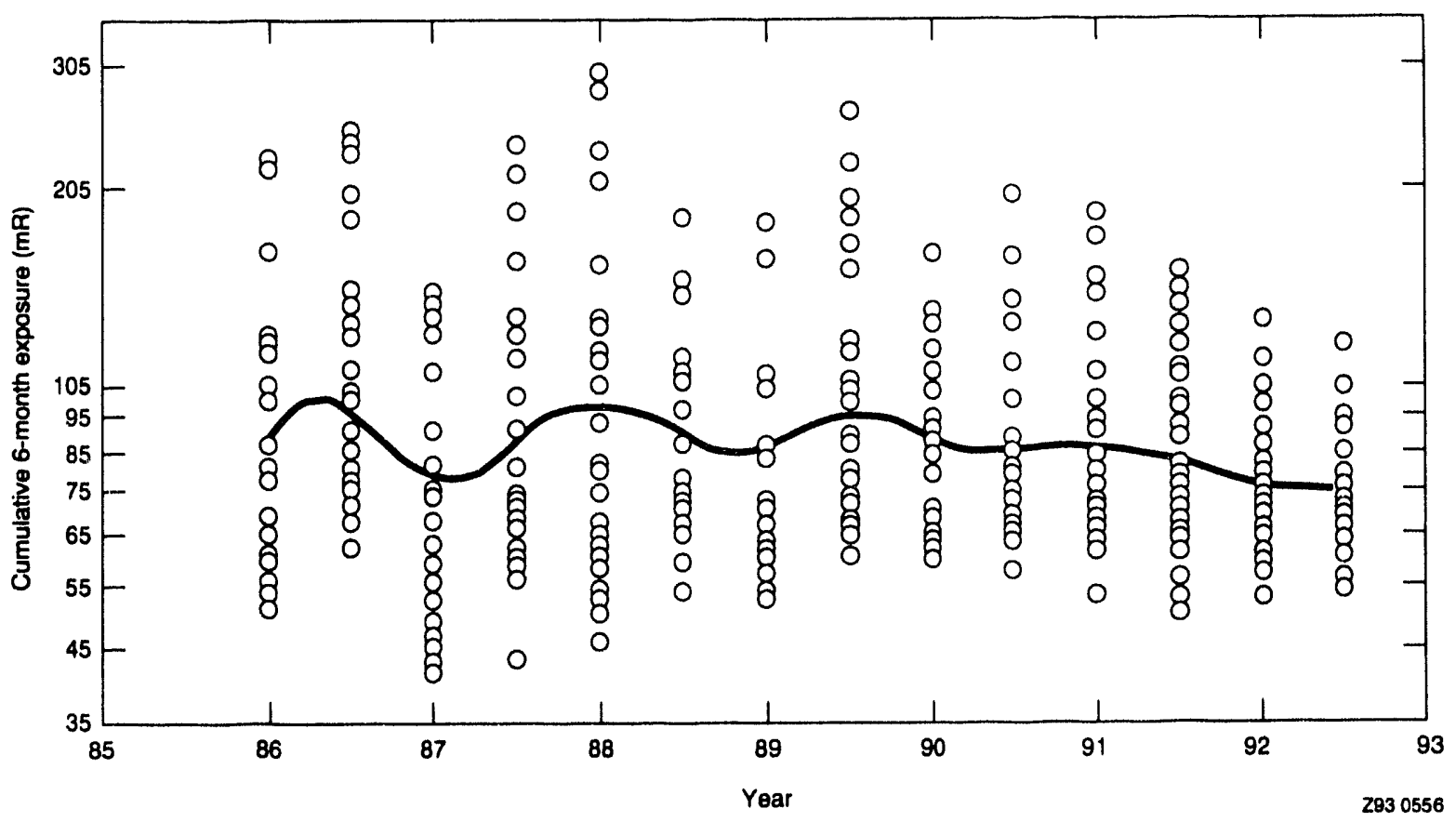

Figure 42. Exposure trends for the spring and fall average TLD measurements.

Figure 34 presents plots of exposures measured at stations 9,11 , and 13 (along the northwest SDA border). Station 9 is located near the west end of $P a d A$, and stations 11 and 13 are located along the northern part of the original burial ground (operated from 1952 through 1957). This area contains buried LLW intermixed with TRU waste. The exposures at station 9 have generally decreased over time, with periodic spikes (e.g., during the second half of 1982). The exposures during the second half of 1982 through the first half of 1984 can be correlated to the temporary parking of vehicles carrying waste shipments on the west side of Pad A. Exposures have decreased at locations 9,11 , and 13 over the years and remain at near background levels for both 1992 reporting periods.

Exposures measured at stations 3, 5, and 7 (northeast SDA border) are plotted in Figure 35. Station 3 is located near Pit 9, which contains TRU waste, and station 5 is located near Pit 8 , which contains LLW. Both pits were closed in
1969. Station 7 is located near the east end of Pad A. In the past (except during 1974 and 1978), the exposures have been consistent over time and were approximately twice the background exposures. Exposure rates returned to twice the background levels of 1989. However, during 1985 through 1988, waste was temporarily stored east of these locations and contributed to the increase exposure rate during these years. Data collected during 1992 shows exposures approaching background levels. This trend is due to increased soil cover in the active area.

Figure 36 shows exposures measured at stations 23 and 25 , which are located along the south central border of the SDA. The trenches near these stations contain LLW intermixed with TRU waste, and were closed in 1959. The exposures at these stations have generally decreased, and are now at or near background exposure levels. 
Figure 37 shows exposures measured at stations 19 and 21 , which are located along the southwest border of the SDA. These stations are located near soil vaults, which are cylindrical holes drilled into the ground. Soil vaults have been designed for disposal of special wastes with radiation levels exceeding $500 \mathrm{mR} / \mathrm{h}$ at $0.91 \mathrm{~m}$ ( $3 \mathrm{ft}$ ). The soil vaults in this area have been closed since 1979. Since 1982, exposures continue to be consistently close to or equal to the background exposure levels.

The exposures plotted in Figure 38 are for stations 27 and 29, which are located on the southeast border of the SDA, south of Pit 17 (which is active). Since the early 1980s, before Pit 17 was active, the exposures remained consistent at two times the background exposure levels. In recent years, these exposures have decreased and are approaching background levels due to increased soil cover at the active pit.

Figure 39 presents plots of exposures measured at stations 15 and 17 , which are located on the west SDA border (next to the original burial ground). Recent exposures have been variable due to operational activities but generally have decreased over time. Current exposures are near background levels.

Figures 40 and 41 show that exposures at stations $1,31,33$, and 35 have been decreasing. These are the closest stations to the pits that have been active since 1974 . Generally exposures measured at these stations have been the highest observed at the SDA and vary with the proximity and intensity of operational activity. No more data are available from stations $1,31,33$, and 35 due to construction in the area. Data are reported for the second half of 1989 through 1992 at stations $1 \mathrm{~B}, 31 \mathrm{~B}, 33 \mathrm{~B}$, and 35B. These locations are $15 \mathrm{~m}(50 \mathrm{ft})$ east of the original locations and are closer to the Intermediate Level Transuranic Storage Facility (ILTSF) at TSA. Current exposures are approximately three times background exposures; however, these stations are in close proximity to the active pit area. Recent exposures at these stations have been decreasing due to the additional soil cover.

Figures 43 through 46 , are plots of exposures measured by TLDs along the north, south, and east borders of the TSA, respectively.

Exposures measured at stations 37,39 , and SWEPP 1, which are located along the north border of the TSA, are plotted in Figure 43. The exposures at these locations are variable over time. These stations are near an area where incoming shipments are placed until the waste can be disposed of. These waste shipments are, in effect, point sources of radiation. Another factor in the variability of the past years exposures at these stations was the temporary storage of waste on the asphalt pad in the TSA area during the late 1980s. Exposures at station 37, located in the area of the active pit, have been decreasing and are approaching background levels. No waste has been stored in this area for the past three years. The exposures at station 39 and SWEPP 1 have been consistent during the past three years at approximately two times the background level.

Exposures measured at stations 42, 43, 45, and SWEPP 5, which are located along the south and southeast borders of the TSA, are shown in Figures 44 and 45 . These exposures are consistently low and usually vary directly with background exposures. No waste is stored near these stations.

Exposures measured at stations 40 and 41 , which are located along the east and northeast borders of the TSA, are shown in Figure 46. Station 41 exposures are fairly consistent and are close to background exposures. Station 40 showed a lage increase during the second half of 1987 , and then returned to its typical range. The 1987 increase has been attributed to the temporary storage of drums near the drum venting station during that year. Current exposures are at or near background exposures. 


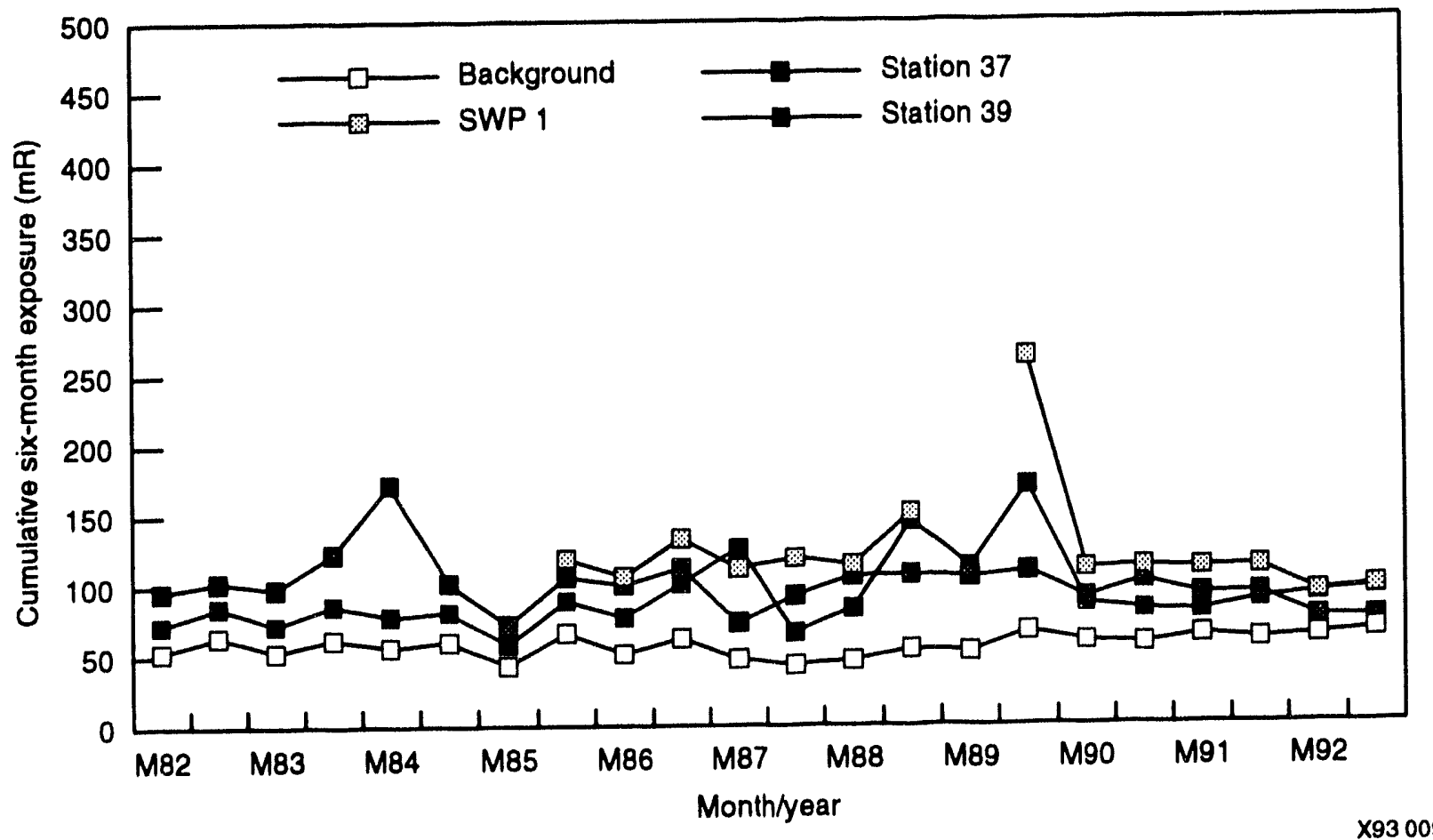

Figure 43. Six-month exposures measured by TLDs on the north border of the TSA.

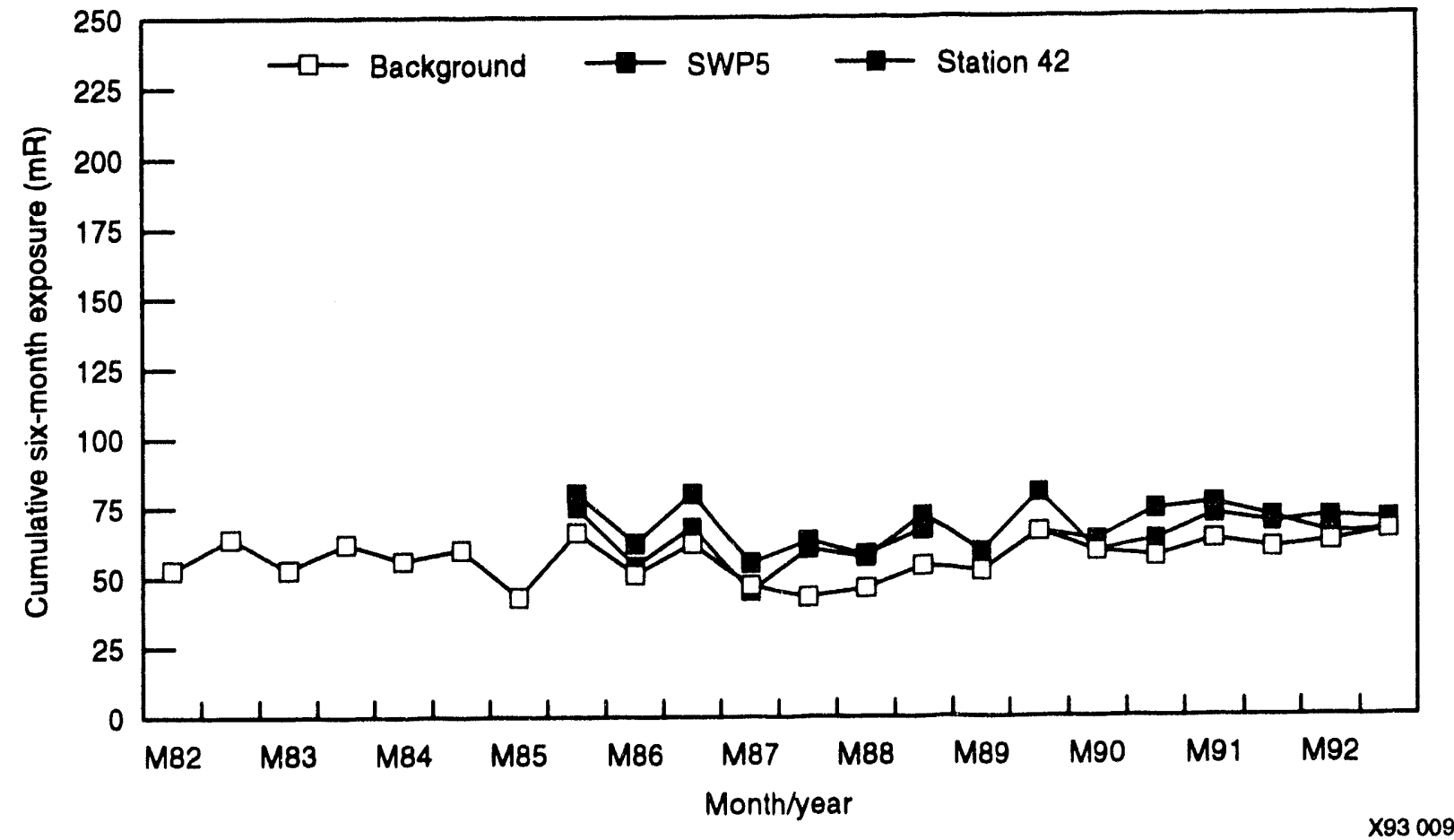

Figure 44. Six-month exposures measured by two of the four TLDs on the south and southeast borders of the TSA. 


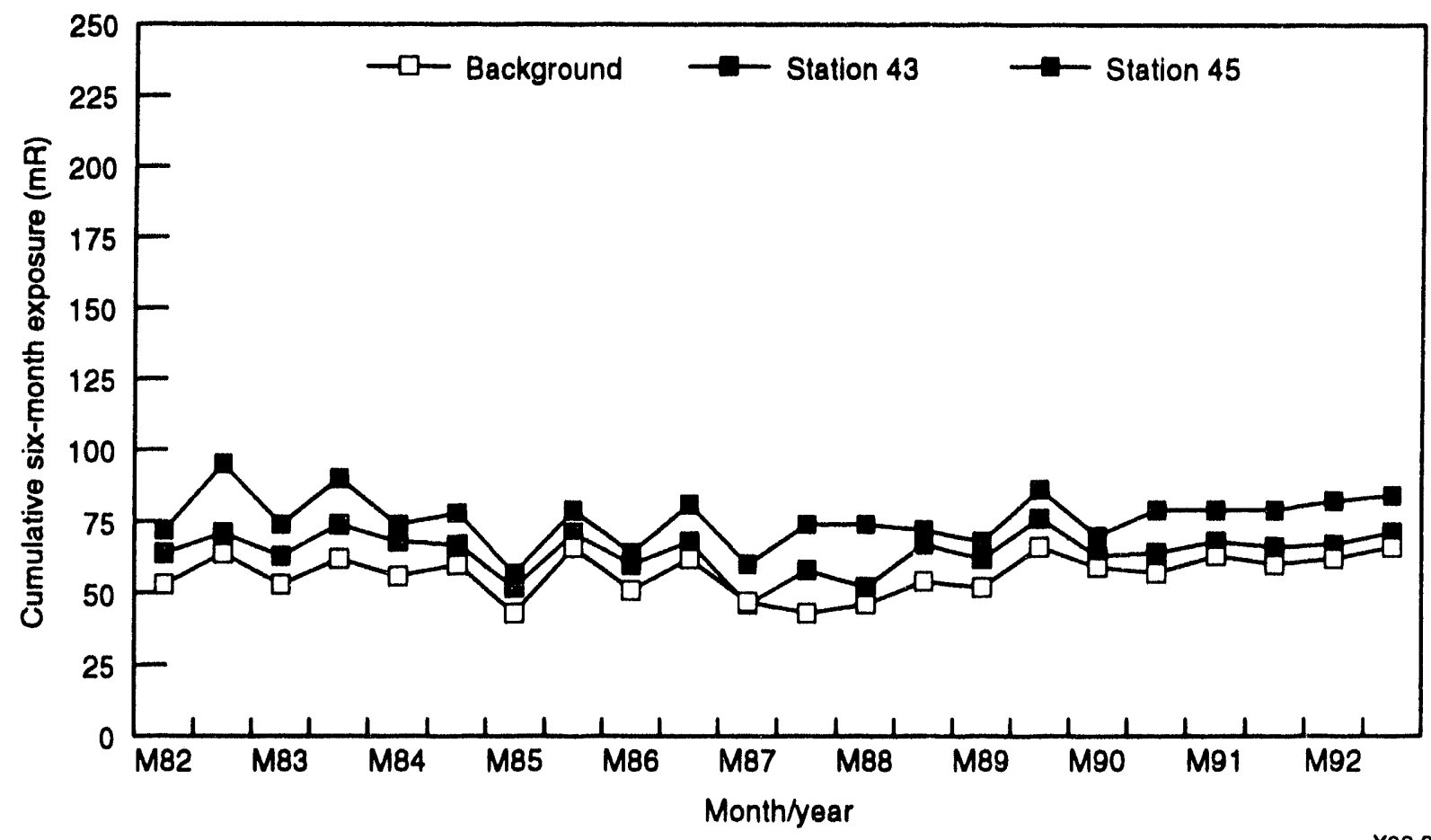

X93 0122

Figure 45. Six-month exposures measured by TLDs on the south border of the TSA.

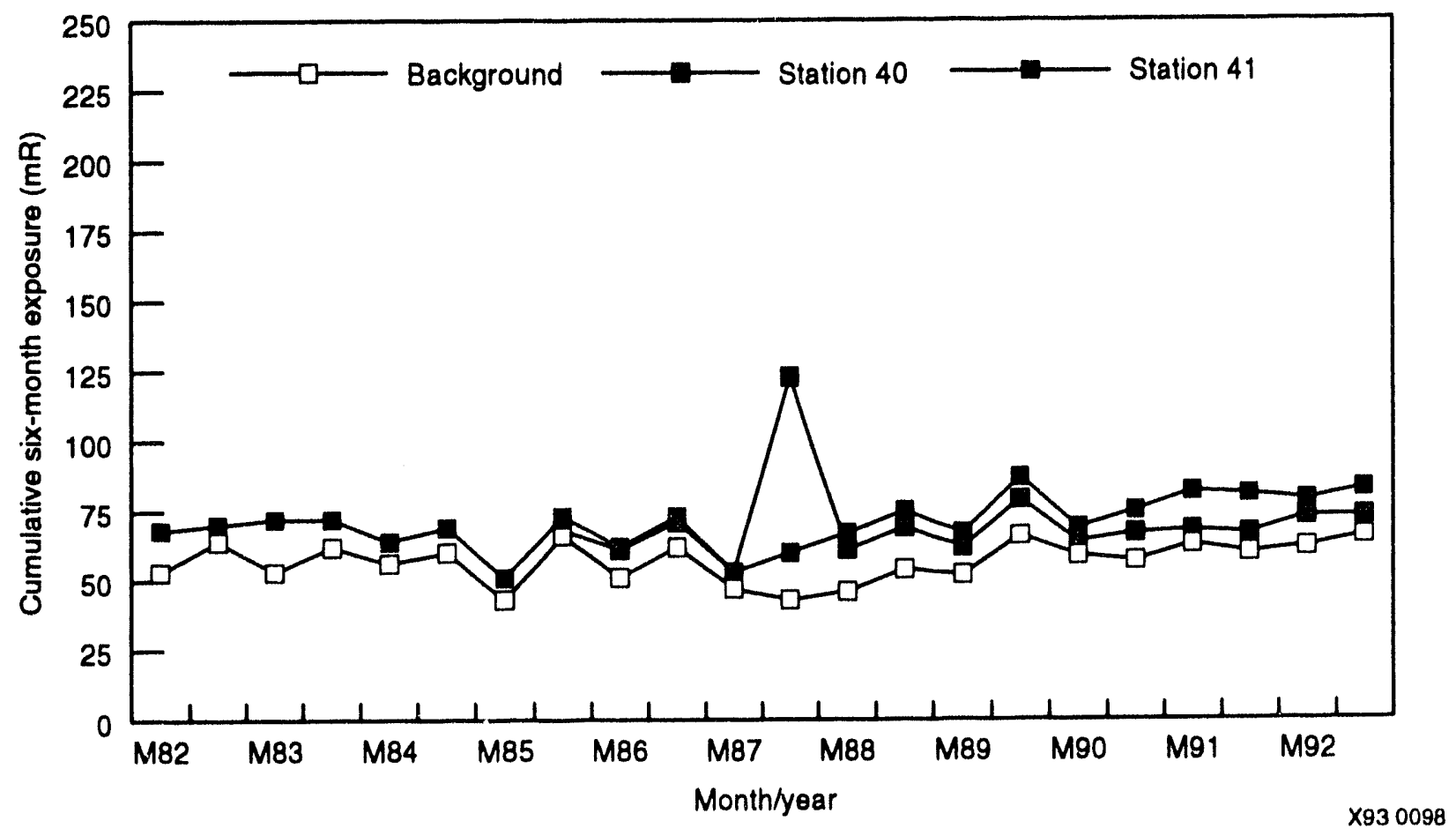

Figure 46. Six-month exposures measured by TLDs on the east and northeast borders of the TSA. 
Figure 47 shows exposures measured at Stations 46 and 47, located along the north border of TSA. In May 1989, these two stations were added by RESL since the security fence had been expanded. These exposures are fairly consistent with background exposures.

\section{Waste ExperImental Reduction Facllity}

Figure 31 shows the locations of the 11 TLD stations located around the WERF. Figures 48 through 52 show the six-month exposures measured by TLDs located in the WERF area.

Figures 48 and 49 show the exposures measured at stations $1,2,3$, and 4 , which are located northeast of WERF along the predominant wind direction. Stations $1,2,3$, and 4 are located $500 \mathrm{~m}$ (1640 ft), $400 \mathrm{~m}$ (1312 ft), $300 \mathrm{~m}$ $(984 \mathrm{ft})$, and $200 \mathrm{~m}(656 \mathrm{ft})$ from WERF, respectively. These exposure levels remain at or near background.

Figures 50 and 51 show the exposures measured at stations 5, 6,7, and 8, which are located $50 \mathrm{~m}(164 \mathrm{ft})$ from WERF in the following directions, respectively: northeast, southeast, southwest, and northwest. Station 5 is located near an area where waste is stored prior to processing. This accounts for the increase in exposures at stations 5 and 8 during 1988 and the continued increase at station 5 during 1989. Some of the waste stored in the storage area adjacent to station 5 was removed during the first half of 1990 . Some variability in exposures, especially at locations 5 and 8 , is due to temporary parking and storage of waste shipments in those areas; these waste shipments are, in effect, point sources of radiation. Waste stored in the storage area adjacent to station 8 was removed during the second half of 1989. Exposures at station 8 have retumed to or near background exposures. Part of the waste stored near location 5 was removed in 1990. Location 5 was removed during 1992 due to construction in the area. This TLD station will be relocated during 1993. Exposures at both stations 6 and 7 have been fairly consistent over time and have been close to background exposures
Figure 52 shows the exposures measured at stations 9,10 , and 11 , which are located $400 \mathrm{~m}$ $(1312 \mathrm{ft})$ from the WERF area in the following directions, respectively: northwest, southwest, and southeast. The exposures at each of these stations have remained fairly consistent over time and are approaching the background exposures.

\section{Surface Radiation}

To conduct the surface gamma-radiation surveys, a vehicle-mounted roadway monitor-1 (VRM-1) gamma-radiation detector system using plastic scintillation detectors (shown in Fig-

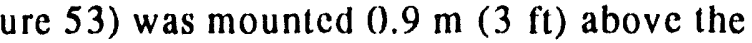
ground on the front of a four-wheel-drive vehicle. The vehicle was driven at approximately $5 \mathrm{~km} / \mathrm{h}(3 \mathrm{mph})$ across each area. As radiation levels greater than background levels were identified, the vehicle was stopped and the area was surveyed with a gamma-sensitive portable instrument. Any areas exceeding the facility limits were marked with flagged stakes for subsequent covering with additional soil.

\section{Radloactive Waste Management Complex}

The contact radiation readings of the 1992 spring and fall surveys at the RWMC are shown in Figure 54. All areas surveyed outside of the active pit were below the limit of $1 \mathrm{mR} / \mathrm{h}$ at $0.9 \mathrm{~m}$ ( $3 \mathrm{ft}$ ), as specified by the RWMC Project Directives. ${ }^{17}$ The $1 \mathrm{mR} / \mathrm{h}$ criteria at $0.9 \mathrm{~m}$ ( $\left.3 \mathrm{ft}\right)$ ensures that personnel are not subjected to significant radiation exposure. Areas were identified having radiation levels exceeding background levels. These areas were documented and will be surveyed again in the future. The highest reading noted in both surveys was $1.80 \mathrm{mR} / \mathrm{h}$ at contact and $0.49 \mathrm{mR} / \mathrm{h}$ at $0.91 \mathrm{~m}(3 \mathrm{ft})$. This location was found along Soil Vault Row 7.

The elevated radiation levels shown on the sides of Pit 17 were a result of the large volume of exposed waste in the pit. Ten areas with elevated radiation levels were identified in the spring survey that were not detected in the fall survey. This decrease is due to changes in soil depth covering waste in those areas. 


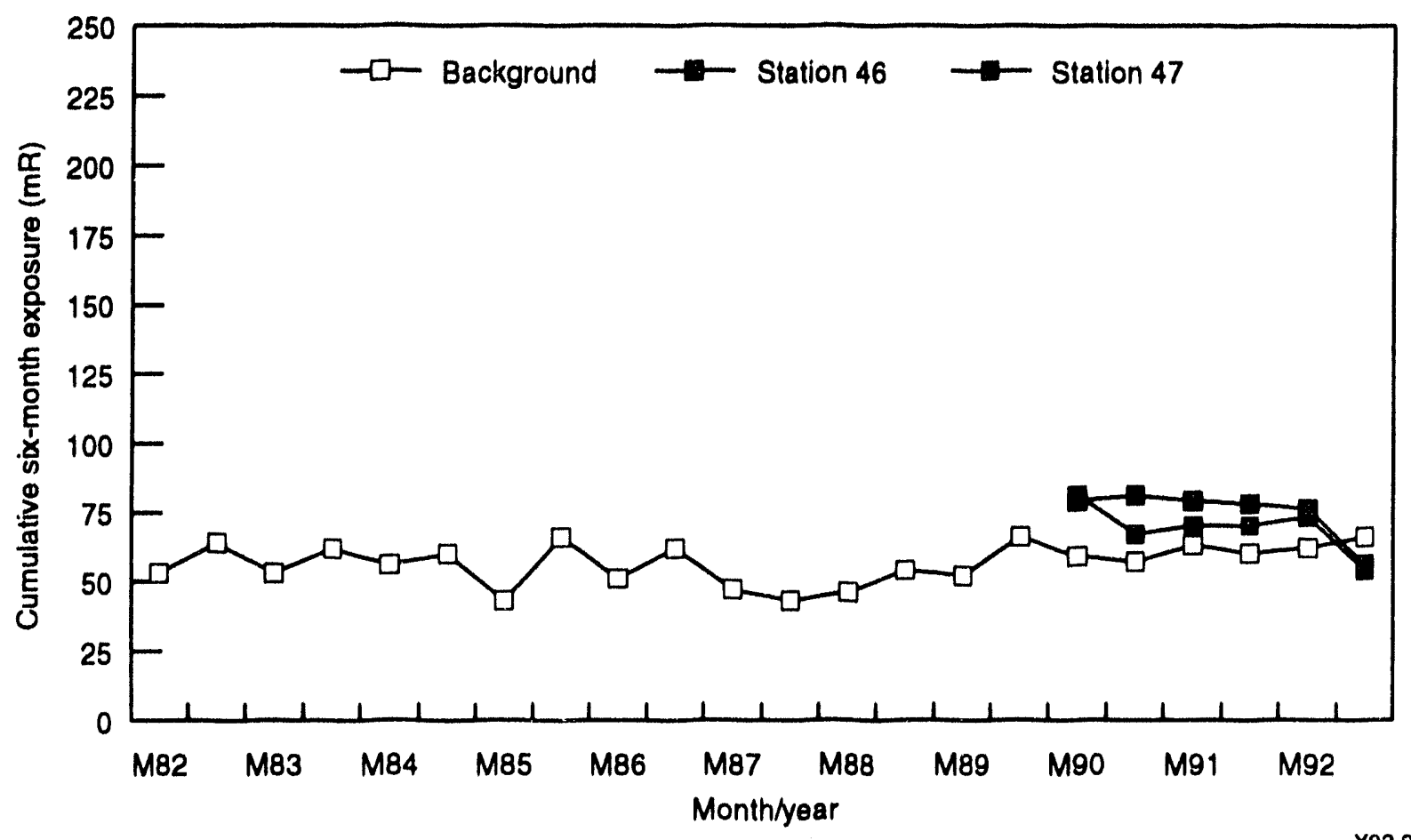

X93 0123

Figure 47. Six-month exposures measured by TLDs north of TSA.

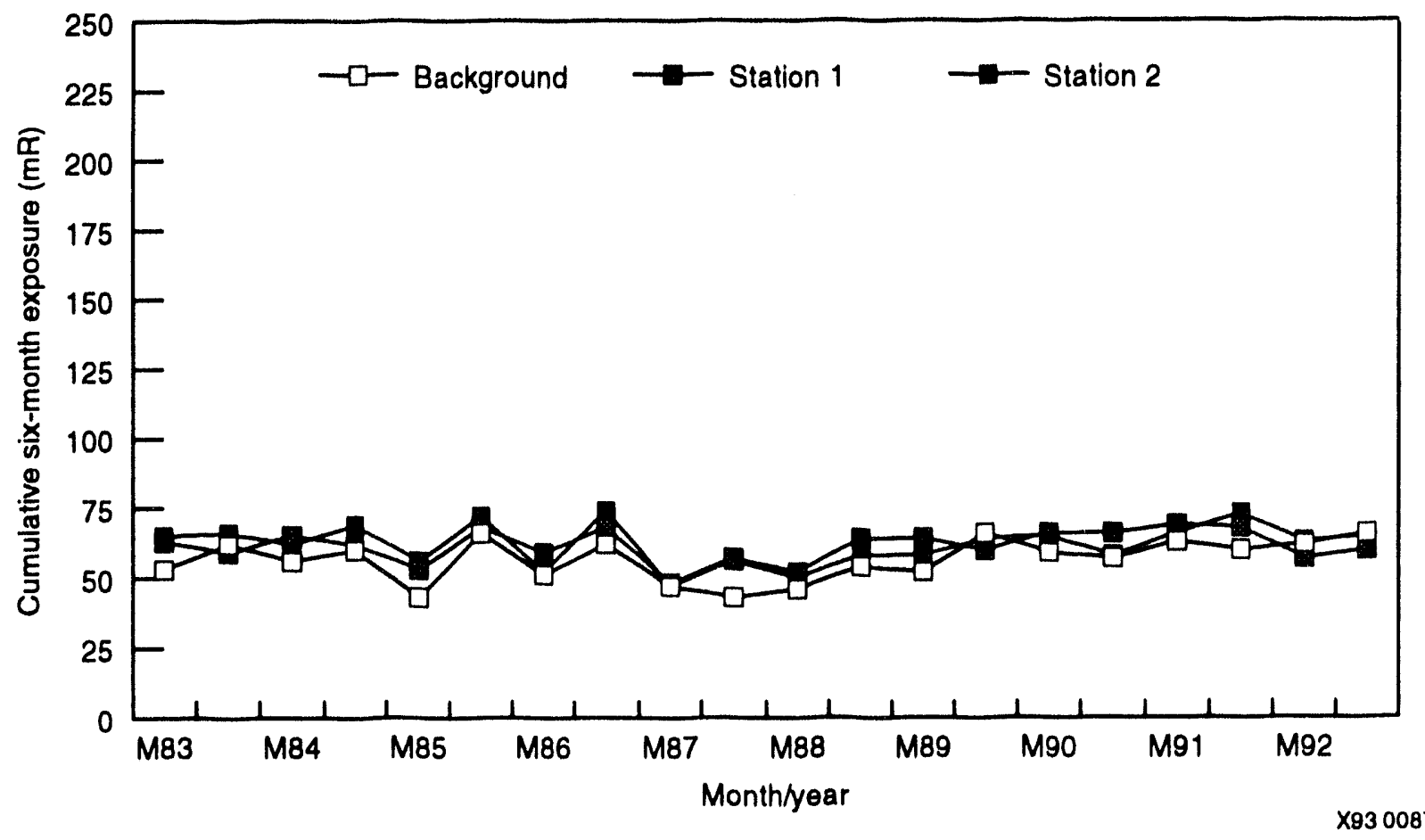

Figure 48. Six-month exposures measured by TLDs located $500 \mathrm{~m}$ and $400 \mathrm{~m}$ northeast of WERF. 


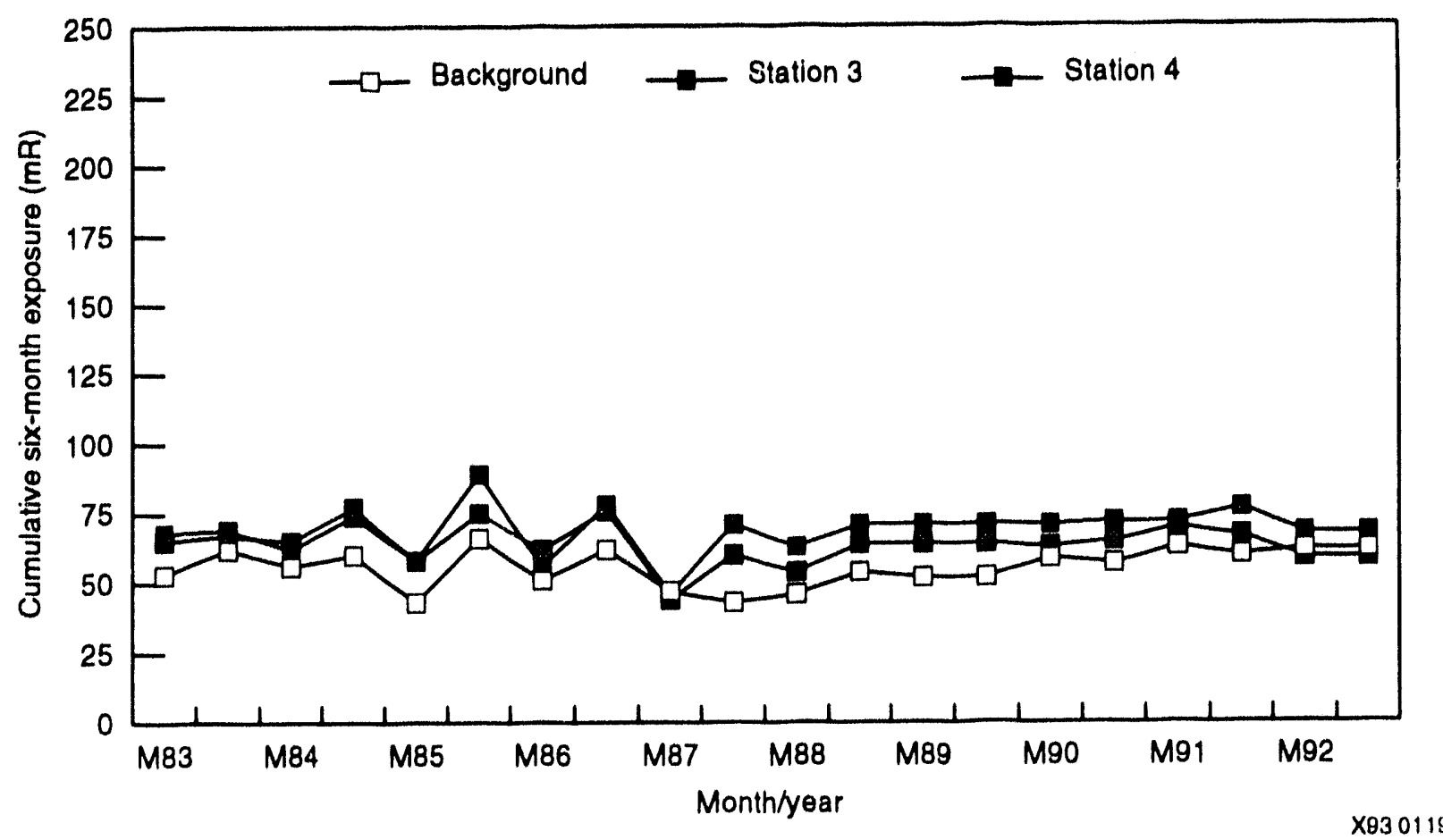

Figure 49. Six-month exposures measured by TLDs located $300 \mathrm{~m}$ and $200 \mathrm{~m}$ northeast of WERF.

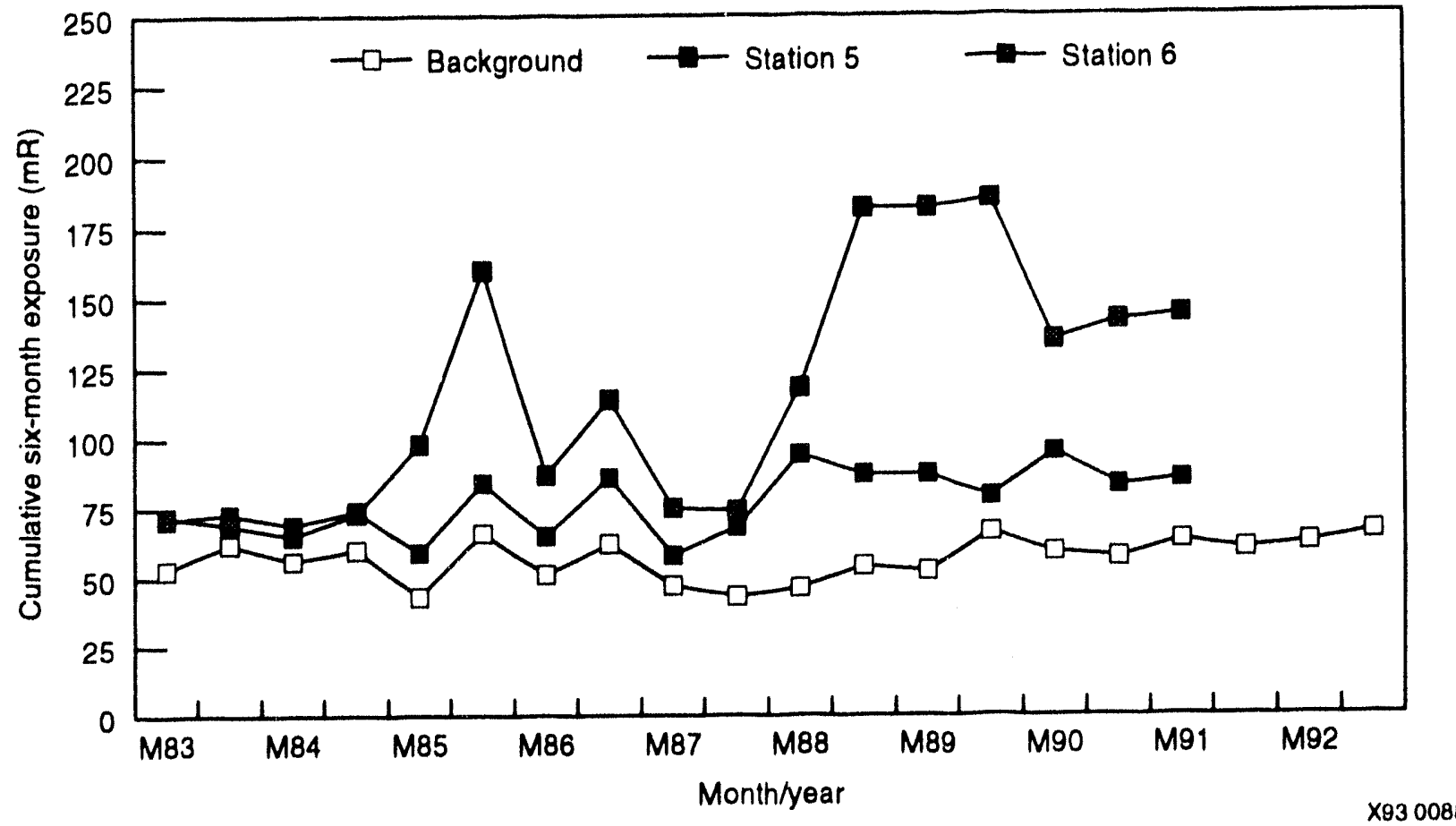

Figure 50. Six-month exposures measured by TLDs located northeast and southeast of the $50-\mathrm{m}$ perimeter around WERF. 


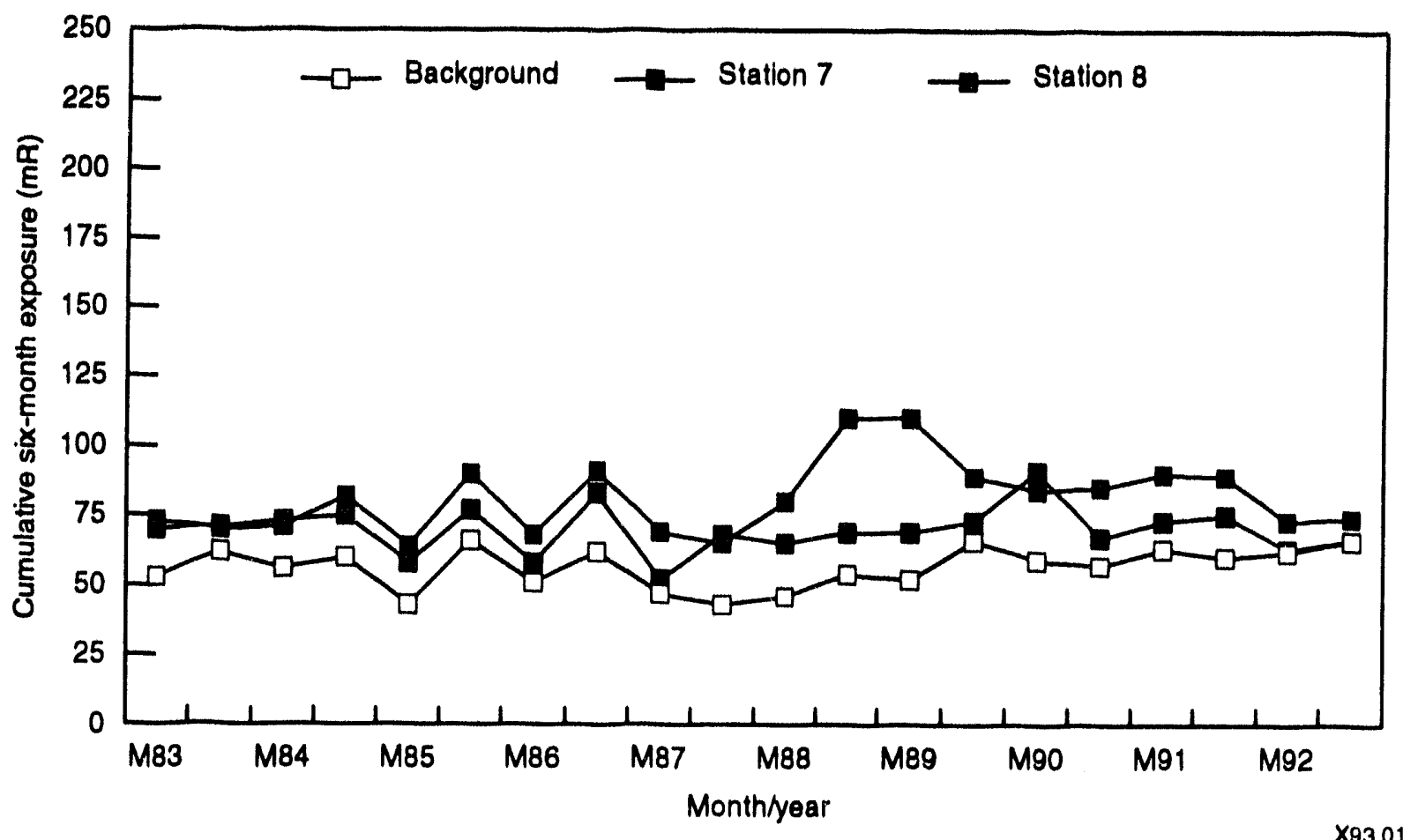

Figure 51. Six-month exposures measured by TLDs located southwest and northwest of the $50-\mathrm{m}$ perimeter around WERF.

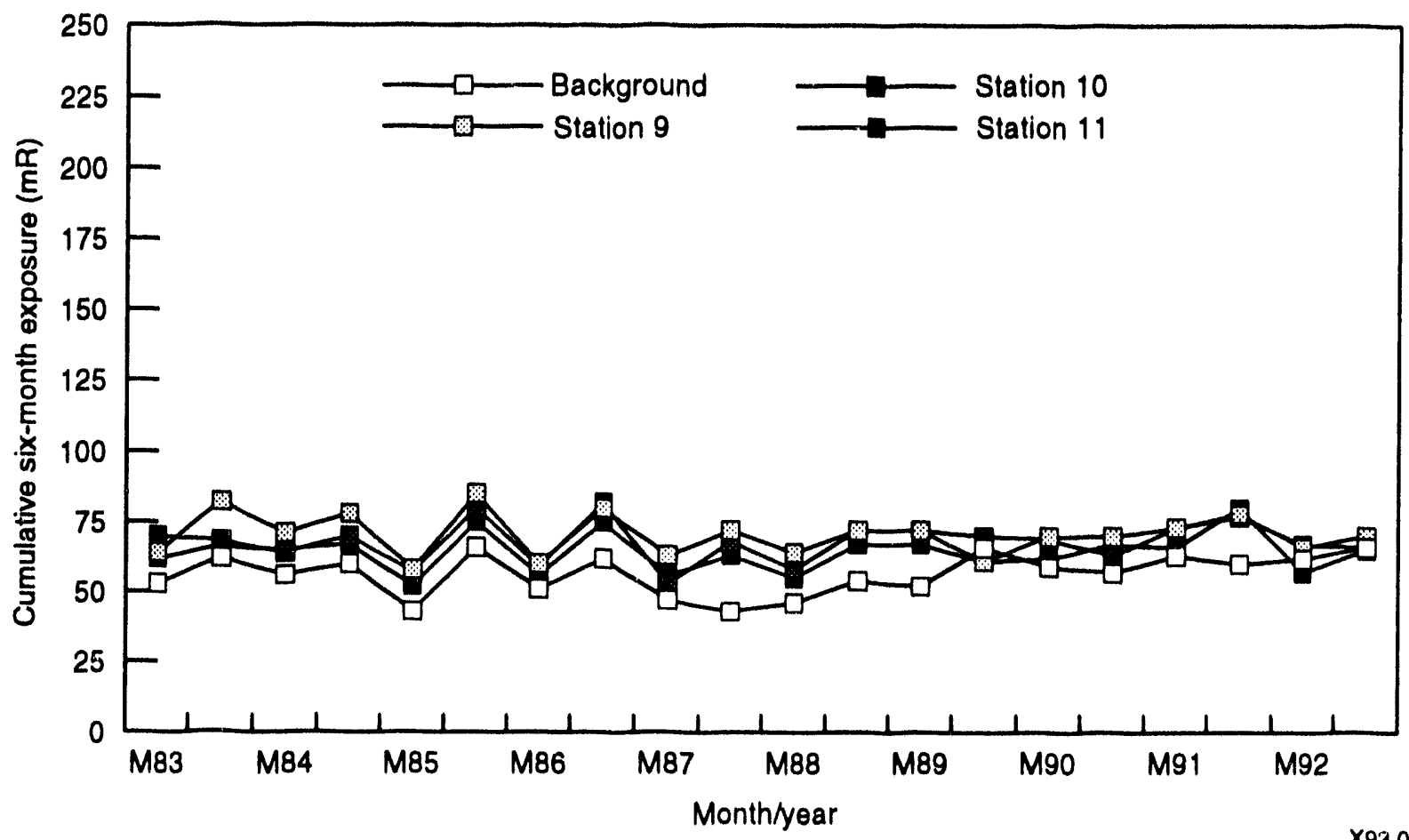

Figure 52. Six-month exposures measured by TLDs at 440-m perimeter around WERF. 


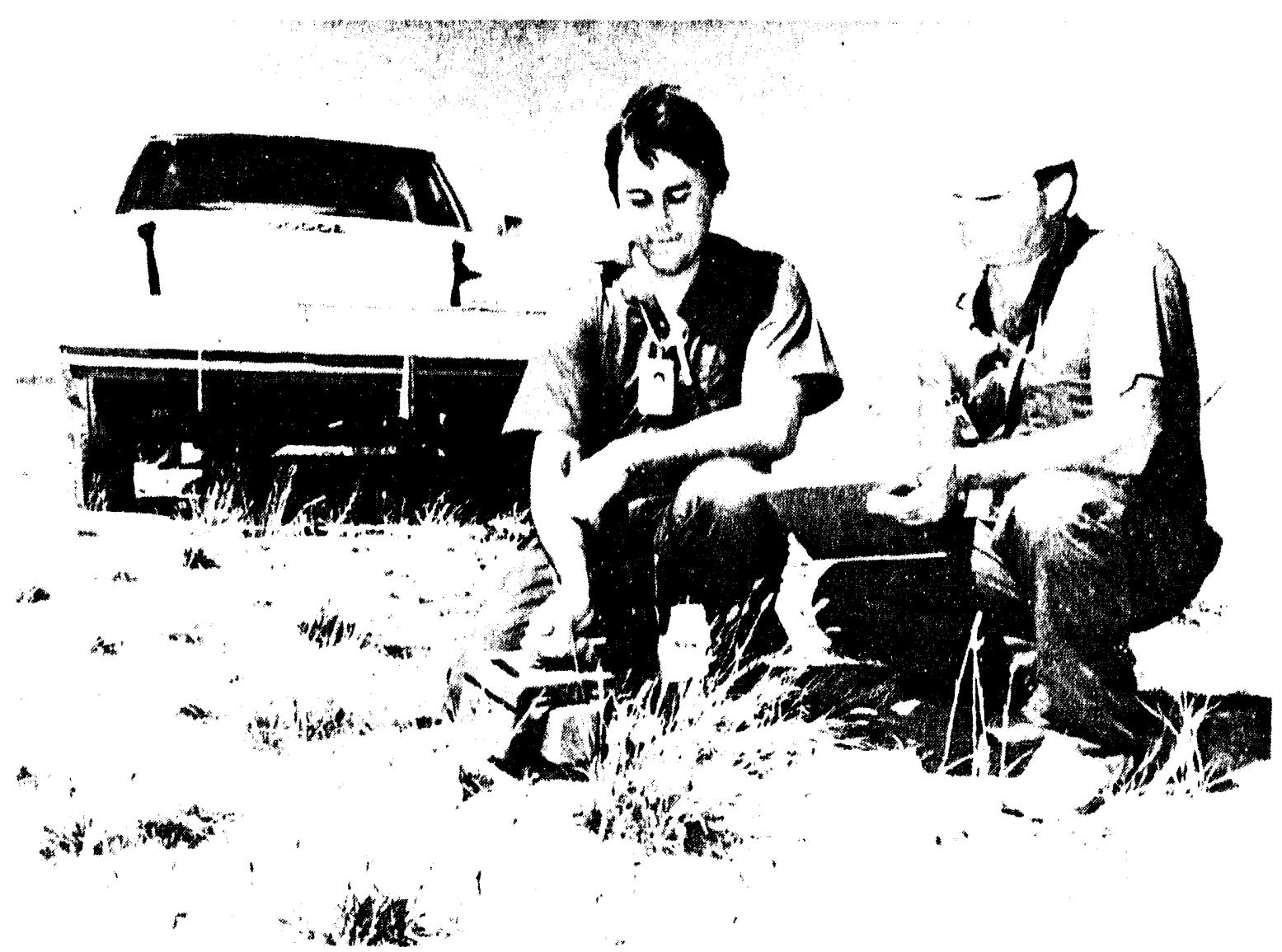

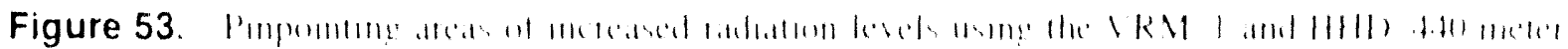

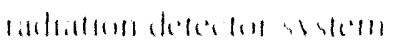



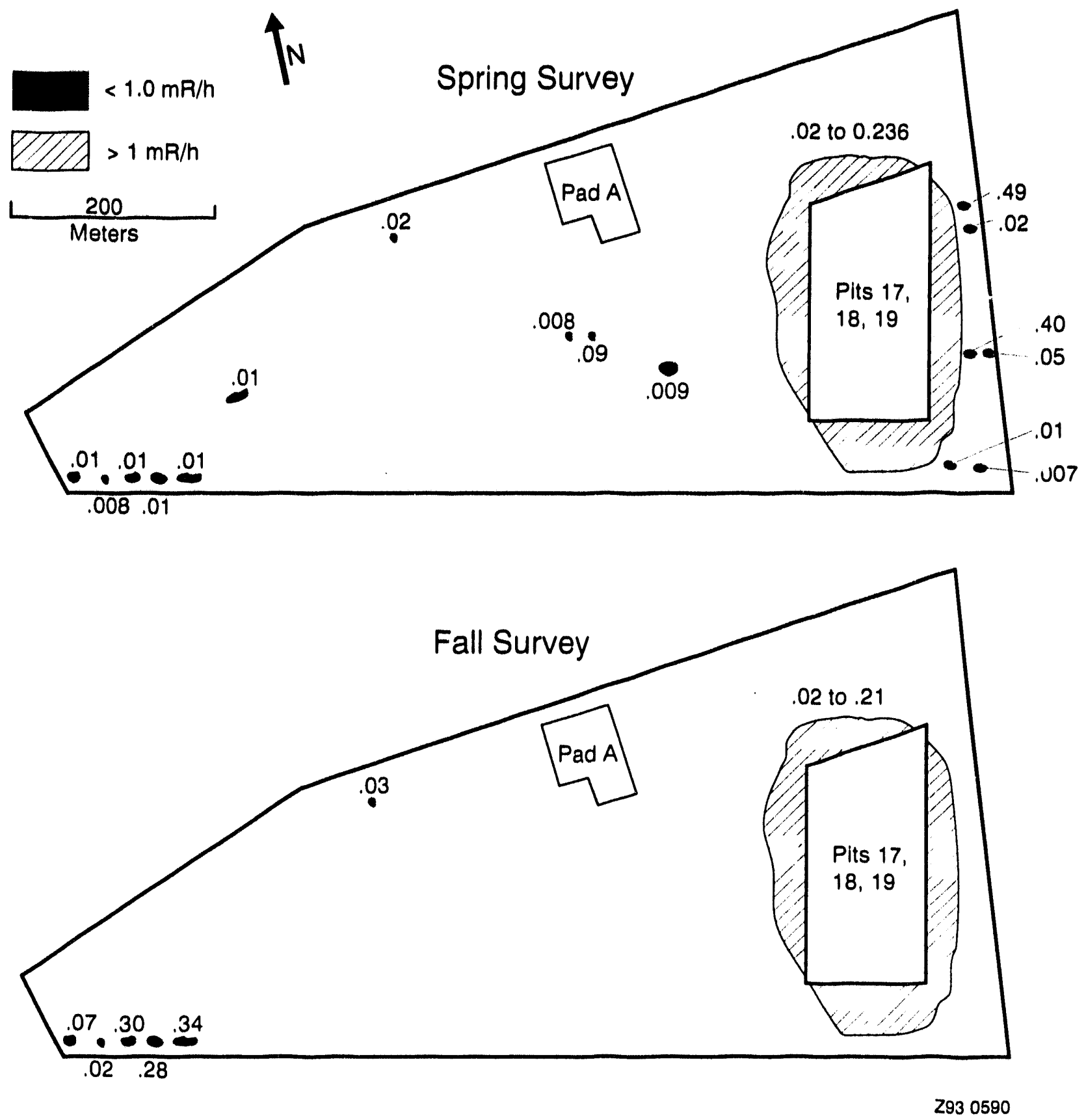

Figure 54. Results of 1992 spring and fall RWMC surface radiation surveys. 


\section{Stationary Low-Power Reactor No. 1}

The SL-1 area location is shown in Figure 1. Results of the spring and fall surface radiation surveys of the $\mathrm{SL}-1$ surplus area identified no areas that exceeded the action level of $20 \mathrm{mR} / \mathrm{h}$ gamma at near contact.

\section{Organic-Moderated Reactor Experiment}

Thirteen areas exceeding background $(0.008 \mathrm{mR} / \mathrm{h})$ were identified during the annual surface radiation survey at OMRE (see Figure 55). None of these areas exceeded the action level of $1 \mathrm{mR} / \mathrm{h}$ at contact. All areas with elevated radiation levels and their associated activities were consistent with those found during previous area surveys. Many of these areas were close to or at the ambient background level. The highest reading was $0.64 \mathrm{mR} / \mathrm{h}$ at contact and $0.03 \mathrm{mR} / \mathrm{h}$ at $0.9 \mathrm{~m}(3 \mathrm{ft})$ and was the only area which exceeded twice the background.

\section{Subsurface Water}

The USGS routinely samples subsurface water from monitoring wells located in and adjacent to the RWMC (see Figure 56). Immediately surrounding the RWMC are USGS wells 87,88 , $89,90,117,119$, and 120 , which penetrate the aquifer approximately $178 \mathrm{~m}(584 \mathrm{ft})$ beneath the surface. USGS well 92, located in the west central portion of the SDA, is used for collecting water samples and monitoring the depth to perched water. In 1973, the well was sealed with expanding cement at a dense basaltic zone about $65 \mathrm{~m}(21.3 .3 \mathrm{ft})$ below the surface, so that perched water could accumulate. Due to the removal of water during sampling, the water level varies between 63.3 and $64.0 \mathrm{~m} \mathrm{(207.7}$ and $210 \mathrm{ft}$ ) below the surface.

Each quarter the USGS measures specific conductance, $\mathrm{pH}$, temperature, and chlorides as well as tritium (H-3) and $\mathrm{Sr}-90$. During 1992 , samples from all eight wells were analyzed for gamma-emitting radionuclides [i.e., cobalt -60 (Co-60) and $\mathrm{Cs}-137 \mathrm{l}$, and transuranics ( $\mathrm{Pu}-238, \mathrm{Pu}-239,-240$, and $\mathrm{Am}-241$ ). In addition, the RWMC production well is sampled monthly for purgeable/organic compounds while all other wells, except well 92, are sampled quarterly.

Since operations began in the 1950s, waste water disposal at the INEL has increased the specific conductance of groundwater in the Snake River Plain aquifer in the vicinity of INEL facilities. The background specific conductance of water from the Snake River Plain aquifer at the INEL generally ranged from $178-860 \mu \mathrm{S} / \mathrm{cm} .^{18}$ This range was compared to the specific conductance measurements of water samples collected from wells at the RWMC in 1992 (see Table 2). These specific conductance measurements are comparable to those made in previous years.

During October of 1992, analyses for stable sodium-22 ( $\mathrm{Na}-22)$ were performed (see Table 2). Water from some of the RWMC monitoring wells contained sodium concentrations higher than the background level of $10 \mathrm{mg} / \mathrm{L}$ (10 ppm). Sodium concentrations have fluctuated in water from these wells. One possible cause for these fluctuations is the method used to construct the wells. During construction, the wells were pressure-cemented to prevent water from cascading from perched zones down to the Snake River Plain aquifer. The cement could attribute to higher sodium concentrations.

The chloride concentration was above background levels also but well below the chloride secondary maximum contaminant level (see Table 2). These concentrations may be from the same process described for sodium. Both the chloride and sodium concentrations are comparable to previous concentrations of past years at these well locations. 


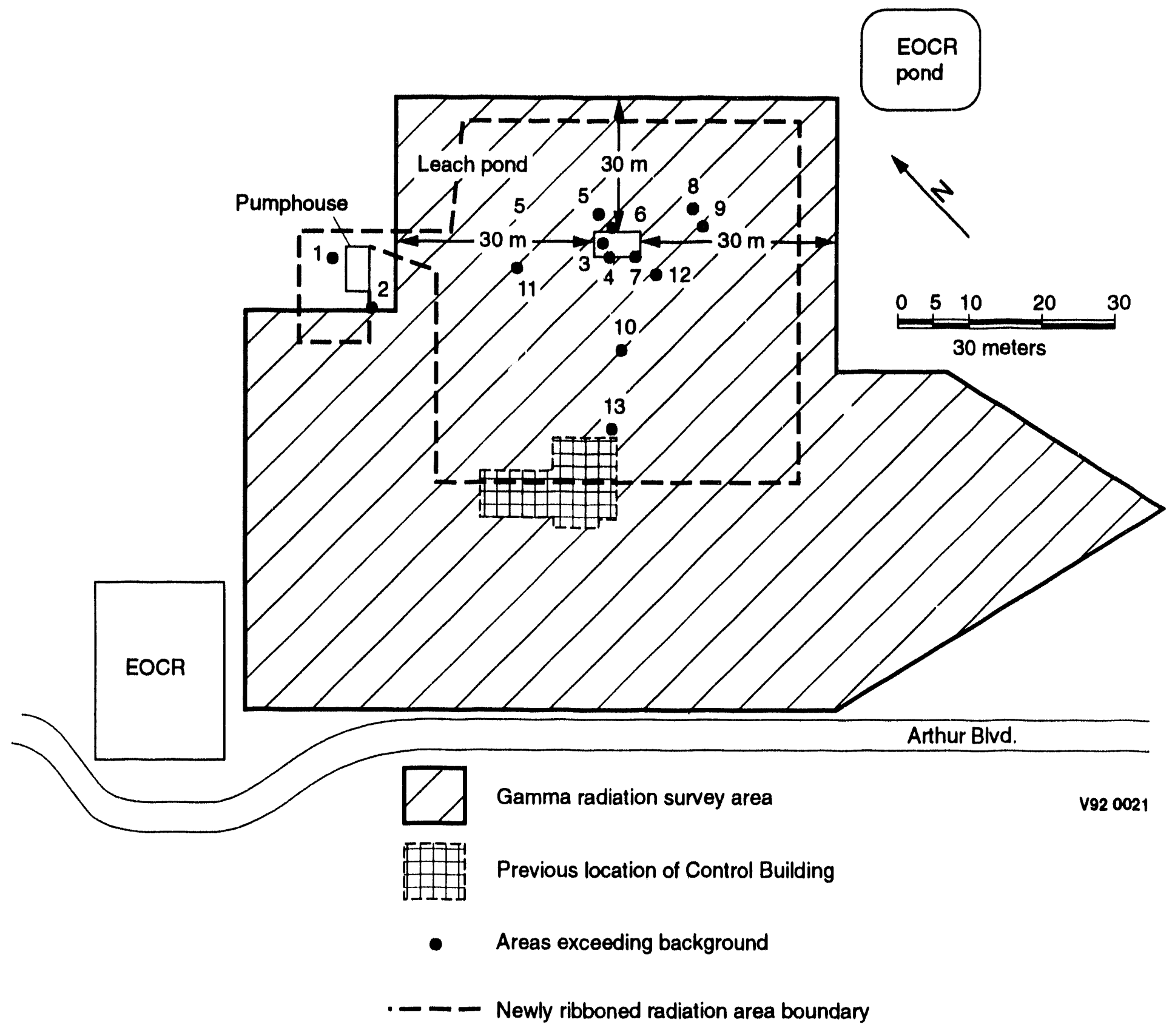

Figure 55. OMRE surface gamma radiation survey area and areas exceeding background levels. 


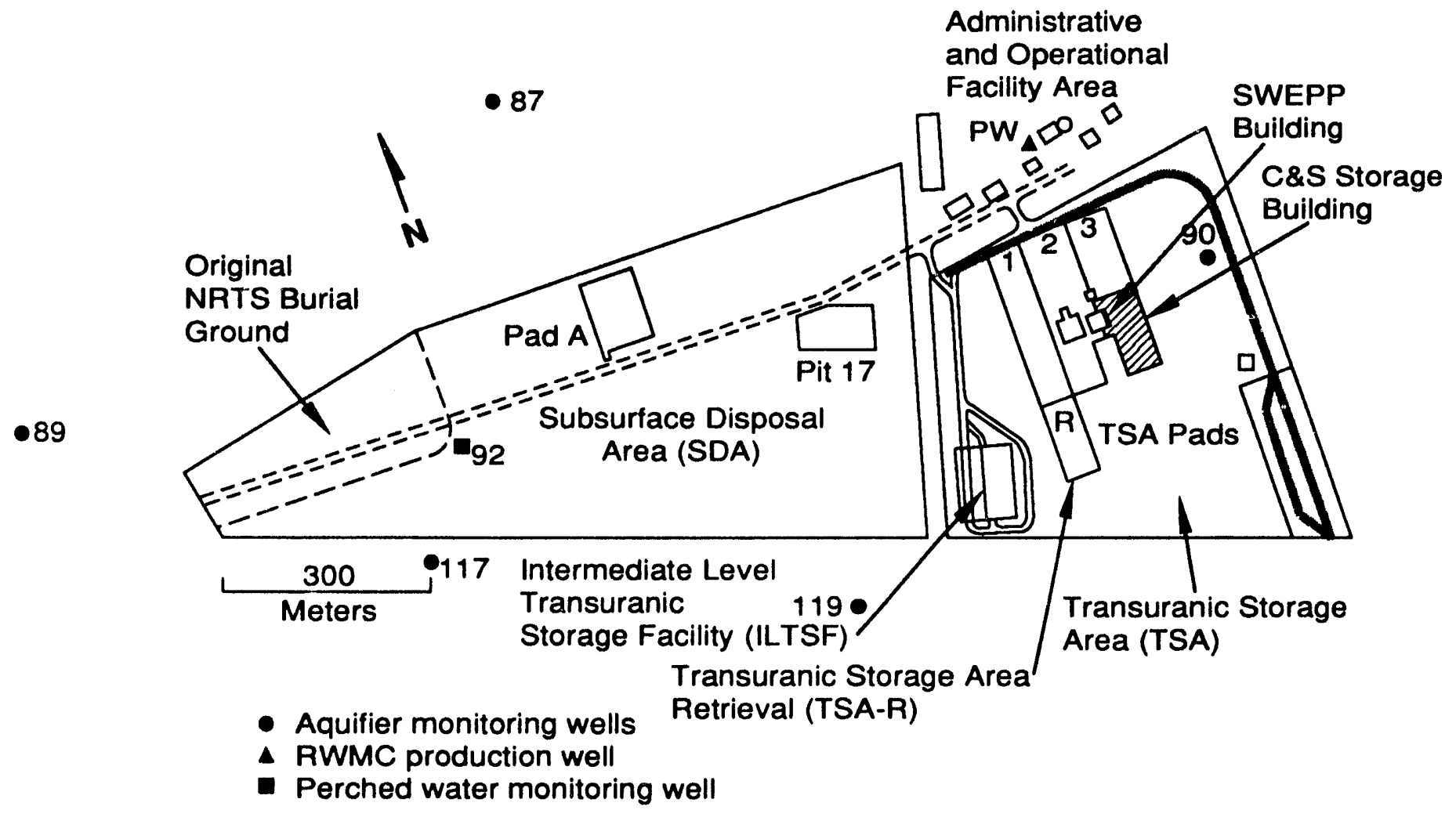

88

Figure 56. USGS well locations. 
Table 2. Results of chemical analyses of subsurface water at the RWMC in 1992.

\begin{tabular}{|c|c|c|c|c|}
\hline \multirow[b]{2}{*}{ Well } & \multirow[b]{2}{*}{ Month Sampled } & \multirow{2}{*}{$\begin{array}{c}\text { Specific } \\
\text { Conductance } \\
\mu S / \mathrm{cm}\end{array}$} & \multicolumn{2}{|c|}{$\begin{array}{l}\text { Concentration } \\
(\mu \mathrm{g} / \mathrm{L})\end{array}$} \\
\hline & & & $\mathrm{Cl}^{-}$ & $\mathrm{Na}^{+}$ \\
\hline \multirow[t]{4}{*}{87} & January & 350 & 14 & - \\
\hline & April & 349 & 15 & - \\
\hline & July & - & 12 & - \\
\hline & October & 335 & 17 & 10 \\
\hline \multirow[t]{4}{*}{88} & January & 582 & 85 & - \\
\hline & April & 565 & 85 & - \\
\hline & July & - & 85 & - \\
\hline & October & 600 & 90 & 44 \\
\hline \multirow[t]{4}{*}{89} & January & 381 & 41 & - \\
\hline & April & - & 40 & - \\
\hline & July & 361 & 40 & - \\
\hline & October & 366 & 42 & 19 \\
\hline \multirow[t]{4}{*}{90} & January & 363 & 14 & - \\
\hline & April & 352 & 17 & - \\
\hline & July & - & 15 & - \\
\hline & October & 348 & 16 & 7.8 \\
\hline \multirow[t]{4}{*}{117} & January & - & 16 & - \\
\hline & April & - & 15 & - \\
\hline & July & - & 14 & - \\
\hline & October & 268 & 16 & 9.7 \\
\hline \multirow[t]{4}{*}{119} & April & - & 10 & - \\
\hline & May & - & 10 & - \\
\hline & July & 271 & 14 & - \\
\hline & October & 274 & 12 & 10 \\
\hline \multirow[t]{4}{*}{120} & January & 448 & 25 & - \\
\hline & April & 442 & 28 & - \\
\hline & July & - & 24 & - \\
\hline & September & 421 & 29 & 25 \\
\hline
\end{tabular}


Table 2. (continued).

\begin{tabular}{|c|c|c|c|c|}
\hline \multirow[b]{2}{*}{ Well } & \multirow[b]{2}{*}{ Month Sampled } & \multirow{2}{*}{$\begin{array}{c}\text { Specific } \\
\text { Conductance } \\
\mu \mathrm{S} / \mathrm{cm}\end{array}$} & \multicolumn{2}{|c|}{$\begin{array}{l}\text { Concentration } \\
\quad(\mathrm{ppm})\end{array}$} \\
\hline & & & $\mathrm{Cl}^{-}$ & $\mathrm{Na}^{+}$ \\
\hline RWMC & January & 360 & 15 & - \\
\hline Production & April & 361 & 16 & - \\
\hline \multirow[t]{3}{*}{ Well } & May & 370 & - & - \\
\hline & July & 372 & 11 & - \\
\hline & October & 350 & 16 & 8 \\
\hline 92 perched & April & 1080 & 89 & - \\
\hline $\begin{array}{l}\text { Natural } \\
\text { background }^{a} \\
\text { (of aquifer) }\end{array}$ & - & $300-325$ & $8-15$ & 10 \\
\hline
\end{tabular}

a. J. R. Pittman et al., Hydrologic Conditions at the Idaho National Engineering Laboratory, Idaho, 1982-1985 update, 89-4008, 1988.

- No sample taken

Approximately 88,400 gal of organic waste were disposed prior to 1970 at the RWMC. ${ }^{19}$ These buried wastes included about $24,400 \mathrm{gal}$ of carbon tetrachloride, $39,000 \mathrm{gal}$ of lubricating oil, and about $25,000 \mathrm{gal}$ of other organic compounds, including trichloroethane, trichloroethylene, perchloroethylene, toluene, and benzene.

Table 3 shows the 1992 concentrations of volatile organic compounds (VOCs) at USGS monitoring wells. The 1992 results are comparable to previous data. No maximum contaminant levels (MCLs) for VOCs or radiological constituents were exceeded during 1992.

The results of the gamma spectrometry analysis performed on well samples taken in
1992 showed no positive detection of any gamma-emitting radionuclide.

Tritium was detected in wells 87 and 90 and in the RWMC production well (see Table 4). No other radionuclides were detected in the wells in any quarter. The average concentrations of tritium in wells 87 and 90 and in the RWMC production well were, respectively, $1.0 \mathrm{pCi} / \mathrm{mL}$, $1.4 \mathrm{pCi} / \mathrm{mL}$, and $1.5 \mathrm{pCi} / \mathrm{mL}$. These concentrations are well below the DCGs for the public (less than $0.1 \%$ of the DCGs, as shown in Appendix C, Table $\mathrm{C}-1$ ). Tritium concentrations in these wells are plotted in Figure 57. The source of the tritium is attributed to past disposal of waste water from operations at the Idaho Chemical Processing Plant and TRA as reported by Orr and Cecil. ${ }^{18}$ 
Table 3. Concentrations ( $\mu \mathrm{g} / \mathrm{L}$ or $\mathrm{ppb})$ of selected volatile organic compounds in groundwater.

\begin{tabular}{|c|c|c|c|c|c|c|c|c|c|c|}
\hline $\begin{array}{c}\text { Well } \\
\text { Identifier }\end{array}$ & $\begin{array}{c}\text { Date } \\
\text { Sampled }\end{array}$ & $\begin{array}{c}\text { Carbon } \\
\text { Tetra- } \\
\text { chloride }\end{array}$ & Chloroform & $\begin{array}{c}1,1,1- \\
\text { Trichloro- } \\
\text { ethane }\end{array}$ & $\begin{array}{l}\text { Trichloro- } \\
\text { ethylene }\end{array}$ & $\begin{array}{l}\text { Tetrachlo- } \\
\text { roethylene }\end{array}$ & $\begin{array}{l}\text { Dichloro- } \\
\text { difluoro- } \\
\text { methane }\end{array}$ & Toluene & $\begin{array}{l}1,1- \\
\text { Dichloro- } \\
\text { ethane }\end{array}$ & $\begin{array}{c}1,1- \\
\text { Dichloro- } \\
\text { ethylene }\end{array}$ \\
\hline \multirow[t]{4}{*}{87} & $1 / 92$ & 0.7 & $<0.2$ & $<0.2$ & 0.2 & $<0.2$ & 0.2 & $<0.2$ & $<0.2$ & $<0.2$ \\
\hline & $4 / 92$ & 0.9 & $<0.2$ & $<0.2$ & 0.2 & $<0.2$ & $<0.2$ & $<0.2$ & $<0.2$ & $<0.2$ \\
\hline & $7 / 92$ & 0.9 & $<0.2$ & 0.2 & 0.2 & $<0.2$ & 0.2 & $<0.2$ & $<0.2$ & $<0.2$ \\
\hline & $10 / 92$ & 0.9 & $<0.2$ & $<0.2$ & 0.2 & $<0.2$ & $<0.2$ & $<0.2$ & $<0.2$ & $<0.2$ \\
\hline \multirow[t]{4}{*}{$88^{a}$} & $1 / 92$ & 1.7 & 0.4 & 0.2 & 0.6 & $<0.2$ & 0.2 & 0.2 & $<0.2$ & $<0.2$ \\
\hline & $4 / 92$ & 1.3 & 0.5 & $<0.2$ & 0.6 & $<0.2$ & $<0.2$ & $<0.2$ & $<0.2$ & $<0.2$ \\
\hline & $7 / 92$ & 1.6 & 0.5 & 0.2 & 0.7 & $<0.2$ & $<0.2$ & $<0.2$ & $<0.2$ & $<0.2$ \\
\hline & $10 / 92$ & 1.2 & 0.5 & 0.3 & 0.7 & $<0.2$ & $<0.2$ & $<0.2$ & $<0.2$ & 0.2 \\
\hline \multirow[t]{4}{*}{89} & $1 / 92$ & - & - & - & - & - & - & - & - & - \\
\hline & $4 / 92$ & $<0.2$ & $<0.2$ & $<0.2$ & $<0 . \overline{2}$ & $<0.2$ & 0.5 & 0.4 & $<0.2$ & $<0.2$ \\
\hline & $7 / 92$ & - & - & - & - & - & - & - & - & - \\
\hline & $10 / 92$ & $<0.2$ & $<0.2$ & 0.2 & $<0.2$ & $<0.2$ & 0.2 & $<0.2$ & $<0.2$ & $<0.2$ \\
\hline \multirow[t]{4}{*}{90} & $1 / 92$ & 1.1 & $<0.2$ & 0.2 & 0.5 & $<0.2$ & 0.4 & $<0.2$ & $<0.2$ & $<0.2$ \\
\hline & $4 / 92$ & 1.2 & $<0.2$ & 0.2 & 0.5 & $<0.2$ & 0.3 & $<0.2$ & $<0.2$ & $<0.2$ \\
\hline & $7 / 92$ & 1.3 & $<0.2$ & 0.4 & 0.4 & $<0.2$ & 0.7 & $<0.2$ & $<0.2$ & $<0.2$ \\
\hline & $10 / 92$ & 1.1 & $<0.2$ & 0.2 & 0.4 & $<0.2$ & 0.4 & $<0.2$ & $<0.2$ & $<0.2$ \\
\hline \multirow[t]{2}{*}{92} & $4 / 92$ & - & - & - & - & - & - & - & - & - \\
\hline & $10 / 92$ & - & - & - & - & - & - & - & - & - \\
\hline \multirow[t]{2}{*}{117} & $1 / 92$ & - & - & - & - & - & - & - & - & - \\
\hline & 4/92 & $<0.2$ & $<0.2$ & $<0.2$ & $<0.2$ & $<0.2$ & $<0.2$ & $<0.2$ & $<0.2$ & $<0.2$ \\
\hline
\end{tabular}


Table 3. (continued).

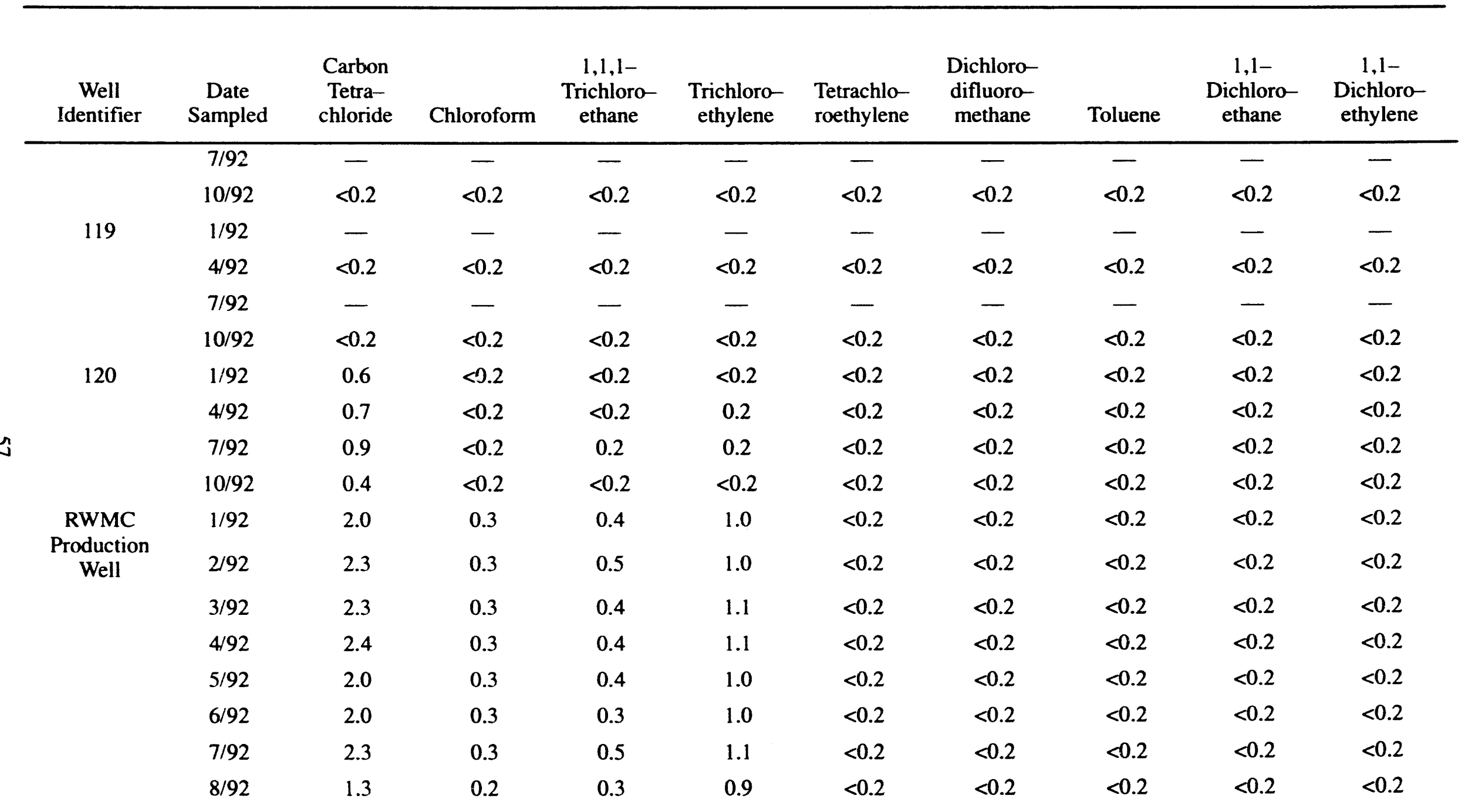


Table 3. (continued).

\begin{tabular}{|c|c|c|c|c|c|c|c|c|c|c|}
\hline $\begin{array}{c}\text { Well } \\
\text { Identifier }\end{array}$ & $\begin{array}{c}\text { Date } \\
\text { Sampled }\end{array}$ & $\begin{array}{l}\text { Carbon } \\
\text { Tetra- } \\
\text { chloride }\end{array}$ & Chloroform & $\begin{array}{c}1,1,1- \\
\text { Trichloro- } \\
\text { ethane }\end{array}$ & $\begin{array}{l}\text { Trichloro- } \\
\text { ethylene }\end{array}$ & $\begin{array}{l}\text { Tetrachlo- } \\
\text { roethylene }\end{array}$ & $\begin{array}{l}\text { Dichloro- } \\
\text { difluoro- } \\
\text { methane }\end{array}$ & Toluene & $\begin{array}{c}1,1- \\
\text { Dichloro- } \\
\text { ethane }\end{array}$ & $\begin{array}{c}1,1- \\
\text { Dichloro- } \\
\text { ethylene }\end{array}$ \\
\hline \multirow{4}{*}{$\begin{array}{l}\text { RWMC } \\
\text { Production } \\
\text { Well }\end{array}$} & 9/92 & 1.9 & 0.2 & 0.4 & 0.8 & $<0.2$ & $<0.2$ & $<0.2$ & $<0.2$ & $<0.2$ \\
\hline & $10 / 92$ & 2.5 & 0.3 & 0.4 & 1.0 & $<0.2$ & $<0.2$ & $<0.2$ & $<0.2$ & $<0.2$ \\
\hline & $11 / 92$ & 2.2 & 0.3 & 0.4 & 0.9 & $<0.2$ & $<0.2$ & $<0.2$ & $<0.2$ & $<0.2$ \\
\hline & $12 / 92$ & 2.1 & 0.3 & 0.5 & 0.9 & 0.2 & $<0.2$ & $<0.2$ & $<0.2$ & $<0.2$ \\
\hline
\end{tabular}

a. Tests specific to pumps and instrumentation were conducted on well 88 during Febuary 1992. The results of these tests are reported in a USGS report titled Purgeable Organic Compounds in the Ground Water at the Idaho National Engineering Laboratory, 1990-1992.20 
Table 4. Results of radiochemical analyses of RWMC subsurface water.

\begin{tabular}{|c|c|c|c|c|}
\hline Well & $\begin{array}{l}\text { Month } \\
\text { Sampled }\end{array}$ & Radionuclide $^{\mathbf{a}}$ & $\begin{array}{l}\text { Concentration } \\
\left(10^{-6} \mu \mathrm{Ci} / \mathrm{mL}\right)\end{array}$ & $\begin{array}{c}\text { Percentage } \\
\text { of } \mathrm{DCG}^{\mathrm{c}}\end{array}$ \\
\hline \multirow[t]{2}{*}{87} & January & $\mathrm{H}-3$ & $0.9 \pm 0.2$ & 0.06 \\
\hline & April & $\mathrm{H}-3$ & $1.0 \pm 0.2$ & 0.06 \\
\hline $88^{d}$ & - & - & - & - \\
\hline $89^{d}$ & - & - & - & - \\
\hline \multirow[t]{2}{*}{90} & January & $\mathrm{H}-3$ & $1.5 \pm 0.2$ & 0.08 \\
\hline & April & $\mathrm{H}-3$ & $1.4 \pm 0.2$ & 0.08 \\
\hline $117^{d}$ & - & - & - & - \\
\hline $119^{d}$ & - & - & - & - \\
\hline $120^{\mathrm{d}}$ & - & - & - & - \\
\hline RWMC Production & January & $\mathrm{H}-3$ & $1.4 \pm 0.2$ & 0.08 \\
\hline \multirow[t]{2}{*}{ Well } & April & $\mathrm{H}-3$ & $1.4 \pm 0.2$ & 0.08 \\
\hline & July & $\mathrm{H}-3$ & $1.6 \pm 0.2$ & 0.08 \\
\hline 92 & April & $\mathrm{H}-3$ & $0.4 \pm 0.2$ & 0.03 \\
\hline Natural Background ${ }^{e}$ & - & $\mathrm{H}-3$ & 0.05 to 0.1 & NA \\
\hline
\end{tabular}

a. No radionuclides detected other than tritium. (See Tables B-1, B-2, and B-3 for limits of detection for other radionuclides.)

b. The \pm values are experimental random uncertainties in the counting measurement process and represent one standard deviation.

c. Derived concentration guide values for the public are based on the dose conversion factors provided in DOE Order 5400.5, "Radiation Protection of the Public and the Environment," February 8, 1990.

d. All radionuclides were below the limit of detection.

e. B. D. Lewis and R. G. Jensen, Hydrologic Conditions at the Idaho National Engineering Laboratory, Idaho, 1979-1981 update, HA-674, 1985. 


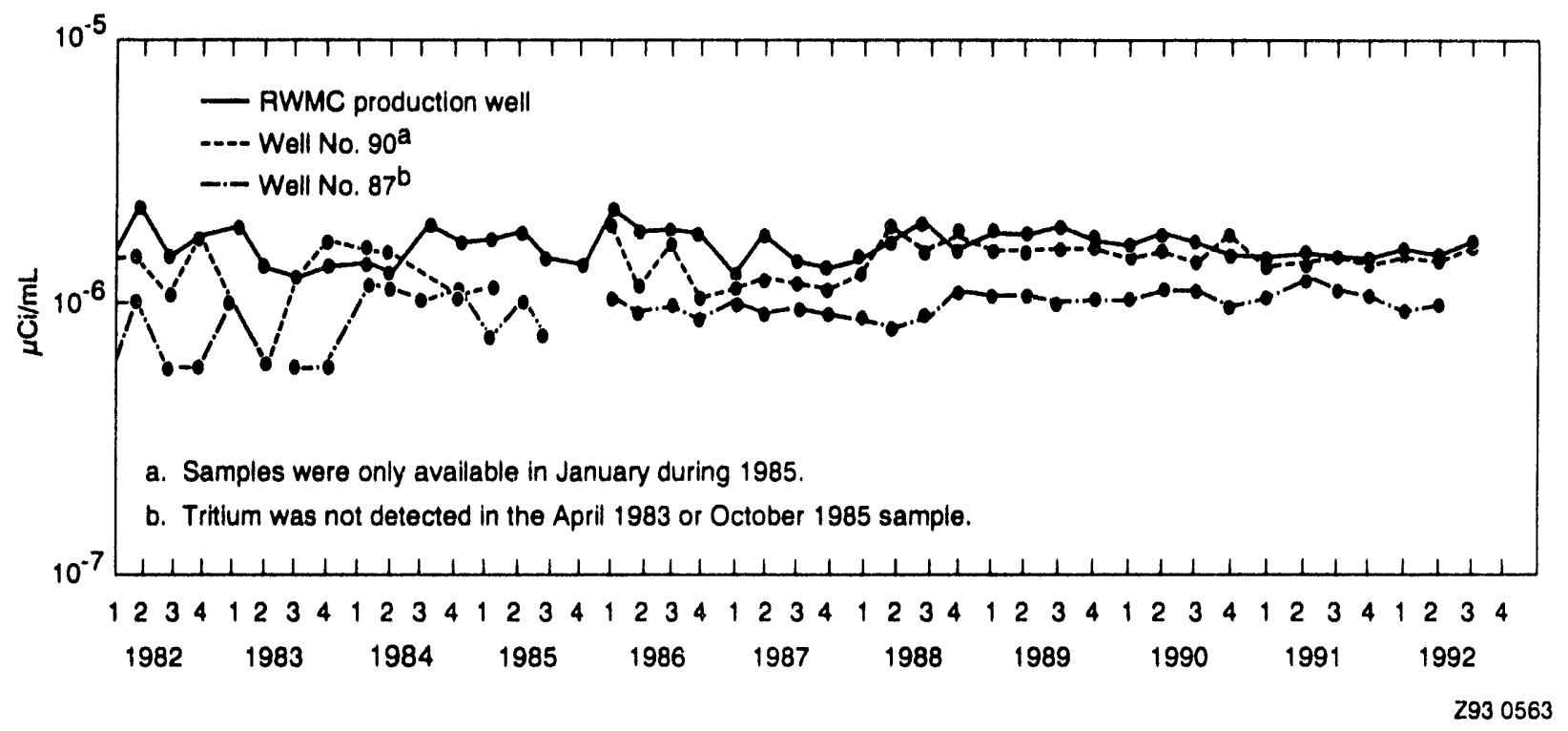

Figure 57. Tritium concentrations in RWMC wells. 


\section{REFERENCES}

1. K. L. Clawson, G. E. Start, and N. R. Ricks, Climatography of the Idaho National Engineering Laboratory, 2nd Edition, DOE/ID-12118, December 1989.

2. R. McBride, W. R. French, A. H. Dahl, and J. E. Detmer, Vegetation Types and Surface Soils of the Idaho National Engineering Laboratory Site, IDO-12084, 1978.

3. L. E. Adams, D. H. Janke, and P. T. Dickman, Annual Report-1978 Environmental Surveillance Report of the INEL Radioactive Waste Management Complex, TREE-1357, 1979.

4. C. R. Groves, The Ecology of Small Mammals on the Subsurface Disposal Area Idaho National Engineering Laboratory, M.S. Thesis, Idaho State University, 1981.

5. Department of Energy, "General Environmental Protection Program," DOE Order 5400.1, November $9,1988$.

6. Department of Energy, "Management of Low-Level Waste," DOE Order 5820.2A, September 26, 1988.

7. O. D. Markham, K. W. Puphal, and T. D. Filer, "Plutonium and Americium Contamination Near a Transuranic Storage Area in Southeastern Idaho," Journal of Environmental Quality, 7, July/ September 1978, pp. 422-428.

8. EG\&G Idaho, Inc., Quality Program Plan for Environmental Monitoring, QPP-029, April 1988.

9. Department of Energy, "Radiation Protection of the Public and the Environment," DOE Order 5400.5, February 2, 1990.

10. J. P. Corley et. al., A Guide for Environmental Radiological Surveillance at U.S. Department of Energy Installations, DOE/EP-0023, July 1981.

11. EG\&G Idaho, Inc., Modifications to RWMC Air Monitoring Activities Recommended by the Monitoring Activities Review, August 23, 1983.

12. J. W. Tkachyk, P. D. Ritter, and R. N. Wilhelmsen, Annual Report--1987 Environmental Surveillance for the EG\&G Idaho Radioactive Waste Management Areas at the Idaho National Engineering Laboratory, EGG-2550, August 1988.

13. EG\&G Idaho, Inc., 1983c, Modifications to RWMC Soil Monitoring Activities Recommended by the Monitoring Activities Review, July 29, 1983.

14. EG\&G Idaho, Inc., 1989, Monitoring Activities Review of the Environmental Monitoring Program, EGG-ESQ-8406.

15. W. J. Arthur, "Radionuclide Concentrations in Vegetation at a Solid Radioactive Disposal Area in Southeastern Idaho," Journal of Environmental Quality, 11, 1982, pp. 394-398.

16. EG\&G Idaho, Inc. 1983d. Environmental Monitoring For the Waste Experimental Reduction Facility At the Idaho National Engineering Laboratory, RHB-132-83. 
17. EG\&G Idaho, Inc., Environmental Handbook for the RWMC and Other Waste Management Facilities, EGG-ER-8045, SOP-EM-EN-1.5, September 30, 1989.

18. B. R. Orr and L. D. Cecil, Hydrologic Conditions and Distribution of Selected Chemical Constituents in Water, Snake River Plain Aquifer, Idaho National Engineering Laboratory, Idaho, 1986 to 1988, U.S. Geological Survey Water-Resources Investigations Report 91-4047, 1991.

19. L. J. Mann and L. L. Knobel, Purgeable Organic Compounds in Ground Water at the Idaho National Engineering Laboratory, Idaho: U.S. Geological Survey Open-File Report 87-776 (DOE/ID-22074), p 23. 
Appendix A

\section{Quality Assurance}

A-1 
A-2 


\section{Appendix A}

\section{Quality Assurance}

The objectives of the QA Program for environmental monitoring activities at EG\&G Idaho facilities at the INEL are to: (a) identify deficiencies in the sampling and measurement processes so that corrective action can be taken, and (b) ensure that the results of the monitoring programs are valid.

Specific elements used to ensure that the objectives of the QA Program are met include:

- Organizational structure and responsibilities of managerial and program personnel

- Program description and objectives

- Program basis and design

- Documented procedures that describe the materials and equipment needed, specific precautions, prerequisites, and step-by-step sampling procedures for monitoring activities

- Data quality objectives

- Document-control processes for the preparation, revision, and approval of procedures

- Sample custody
- Maintenance of records pertaining to monitoring activities, such as planning documents, data sheets, sample results, and calibration records

- Proper calibration and preventive maintenance

- Data reduction and validation procedures

- Analysis of quality control samples (known standards, blank samples, split samples, replicates, and resubmitted samples) to assess accuracy and precision of monitoring results

- Planned and periodic audits as well as self-assessments.

Radioanalytical laboratories provide acceptable results on quality control samples. Program personnel determine whether the analytical results for the control samples are acceptable. The sample media, activity in the quality control sample, and type of analysis are taken into consideration. Each set of known values and laboratory results receives individual consideration. Quality control samples representative of EM Unit air particulate, soil, biota, and water samples are submitted for each sample type. Quality control samples, prepared by EG\&G Idaho Radiochemistry, reflect the concentration levels found in environmental samples. 
Appendix B

Detection Limits

B-1 


\section{Appendix B}

\section{Detection Limits}

\section{RADIOCHEMICAL ANALYSIS DETECTION LIMITS}

Approximate detection limits of present methods used to analyze samples discussed in this report are listed in Tables B-1, B-2, and B-3 for ariety of radionuclides. The limits are based on sample sizes and forms as described in this report. Actual detection limits may vary depending upon background, yield, counting time, and sample volume.

The detection limits given in Table B-1 in terms of activity per unit weight or volume are derived from the total activities in microcuries $(\mu \mathrm{Ci})$ that must be present in the sample aliquot. The detection limits are calculated under the following conditions: a counting time of 1000 minutes, a counting efficiency of about $25 \%$, a chemical yield of about $80 \%$, a clean detector and reagent blanks giving not more than about 5 counts in 1000 minutes in any given energy interval, and calculated according to the definition of detection limits given by L. A. Currie. The detection limit equals $(2.71+4.66$ $\left.\mathrm{B}^{1 / 2}\right) /\left(\mathrm{t} \times \mathrm{E} \times \mathrm{Y} \times 2.22 \times 10^{6}\right)$ total $\mu \mathrm{Ci}$, where " $\mathrm{B}$ " is the total background and blank correction, " $t$ " is the counting time in minutes, " $E$ " is the counting efficiency as a fraction, " $Y$ " is the chemical yield as a fraction, and $2.22 \mathrm{E}+6$ is the $\mathrm{dpm} / \mu \mathrm{Ci}$. These absolute detection limits, in terms of total microcuries per sample, are about $3 \mathrm{E}-6$ for $\mathrm{Sr}-90$, and about $3 \mathrm{E}-8$ for all other alpha-emitting nuclides. To determine the detection limits as activity concentration, as given in Table $\mathrm{B}-1$, the absolute detection limits must be divided by the sample size taken for analysis. On samples, the activity found is divided by the actual sample size analyzed or reported in terms of total activity per sample.

Quality assurance samples are prepared as nearly identically to the real samples as possible. Air samples are simulated by spotting known quantities of activity as uniformly as possible over the filters and drying. Water solutions will contain known quantities of water-soluble tracer solutions.

For soils, 25-g samples of real, minus 200 mesh soil containing exactly known quantities of the radionuclides of interest homogeneously distributed throughout the sample are submitted, of which 10-g samples are analyzed. For dried vegetation and animul tissue, vegetation (avg wt $1(0 \mathrm{~g}$ ), mice (avg wt $55 \mathrm{~g}$ ), or ground squirrels (avg wt $85 \mathrm{~g}$ ) are spiked inhomogeneously with known quantities of radionuclides evaporated to dryness on about $100 \mathrm{mg}$ of clean, dry, minus 100-mesh soil to obtain quantitative transfer without wetting the samples. These samples may not be subdivided without complete dissolution because of their fundamental inhomogeneity.

Two levels of activity are necessary to check both the stated detection limits and to determine the accuracy and precision with which larger activities can be measurted. The lower level consists of activities from about 1.5 to 5 times the stated absolute detection limit to maximize the influence of backgrounds, blanks, and incomplete separation of interferences from the sample on the net activity being measured. No attempt is made to verify stated detection limits by analysis of blank samples. This is due to the statistical uncertainty of a net result obtained by subtracting a reagent blank from a sample that is also blank. Also, several different types of problems can give a blank result even when considerable activity is present. For example, there could be a complete loss of the radionuclide being determined in the absence of a tracer, complete exchange, or sample dissolution, or failure to turn up the high voltage to the detector or power up the instrument. The higher level consists of activities sufficiently high to 
Table B-1. Environmental monitoring samples for radiochemical analysis.

\begin{tabular}{|c|c|c|c|c|}
\hline Media & Sample Description & Method of Treatment & \multicolumn{2}{|c|}{$\begin{array}{c}\text { Detection Limits } \\
(\mu \mathrm{Ci} / \mathrm{g} \text { or } \mathrm{mL})\end{array}$} \\
\hline Air & $\begin{array}{l}\text { Sampled approxi- } \\
\text { mately at } 4 \mathrm{cfm} \text { for } \\
2 \text { weeks on Versapor } \\
1200 \text { filters, } 6 \text { filters } \\
\text { per quarter for a total of } \\
\sim 1.7 \times 10^{10} \mathrm{cc} \text { of air. }\end{array}$ & $\begin{array}{l}\text { Dry ash, dissolve and } \\
\text { analyze the total sample } \\
\text { of } 6 \text { filters. }\end{array}$ & $\begin{array}{l}\mathrm{Sr}-90 \\
\mathrm{Pu}-238 \\
\mathrm{Pu}-239 \\
\mathrm{Am}-241\end{array}$ & $\begin{array}{l}2 \times 10^{-16} \\
2 \times 10^{-18} \\
2 \times 10^{-18} \\
2 \times 10^{-18}\end{array}$ \\
\hline Water & $\begin{array}{l}\text { 4-L collapsible poly- } \\
\text { ethylene container } \\
\text { containing } 25 \mathrm{~mL} \text { of } \\
\text { conc. } \mathrm{HNO}_{3} \text { and } 2 \\
\text { Whatman ashless filter } \\
\text { tablets for } 4000 \mathrm{~mL} \\
\text { water. }\end{array}$ & $\begin{array}{l}\text { Separate and dissolve pa- } \\
\text { per pulp, reconstitute } \\
\text { sample, and boil down to } \\
100 \mathrm{~mL} \text { Analyze } 1 / 2 \\
\text { sample or } 2-\mathrm{L} \text { equiva- } \\
\text { lent. }\end{array}$ & $\begin{array}{l}\mathrm{Sr}-90 \\
\mathrm{Pu}-238 \\
\mathrm{Pu}-239 \\
\mathrm{Am}-241\end{array}$ & $\begin{array}{l}2 \times 10^{-9} \\
2 \times 10^{-11} \\
2 \times 10^{-11} \\
2 \times 10^{-11}\end{array}$ \\
\hline Soil & $\begin{array}{l}\text { At least } 25 \mathrm{~g} \text { in appro- } \\
\text { priate container. Larg- } \\
\text { er quantities are per- } \\
\text { missible if convenient. }\end{array}$ & Analyze $10-g$ sample. & $\begin{array}{l}\mathrm{Sr}-90 \\
\mathrm{Pu}-238 \\
\mathrm{Pu}-239 \\
\mathrm{Am}-241\end{array}$ & $\begin{array}{l}3 \times 10^{-7} \\
3 \times 10^{-9} \\
3 \times 10^{-9} \\
3 \times 10^{-9}\end{array}$ \\
\hline Vegetation & $\begin{array}{l}\text { 16-0z squat jar filled to } \\
\text { rim below threads (avg } \\
\text { wt } 150 \mathrm{~g} \text { ). }\end{array}$ & $\begin{array}{l}\text { Dry ash and dissolve the } \\
\text { total sample completely. } \\
\text { Analyze the equivalent of } \\
50 \mathrm{~g} \text { of original sample. }\end{array}$ & $\begin{array}{l}\mathrm{Sr}-90 \\
\mathrm{Pu}-238 \\
\mathrm{Pu}-239 \\
\mathrm{Am}-241\end{array}$ & $\begin{array}{l}6 \times 10^{-8} \\
6 \times 10^{-10} \\
6 \times 10^{-10} \\
6 \times 10^{-10}\end{array}$ \\
\hline $\begin{array}{l}\text { Animal } \\
\text { Tissue }\end{array}$ & $\begin{array}{l}16-0 z \quad \text { squat jar } \\
\text { containing } 10 \text { dried } \\
\text { deer mice, or } 1 \text { dried } \\
\text { ground squirrel (avg } \\
\text { wts: mice, } 170 \mathrm{~g} \text {; squir- } \\
\text { rel, } 100 \mathrm{~g} \text { ). }\end{array}$ & $\begin{array}{l}\text { Dry ash, dissolve, and } \\
\text { analyze the equivalent of } \\
50 \mathrm{~g} \text { of the original sam- } \\
\text { ple. }\end{array}$ & $\begin{array}{l}\mathrm{Sr}-90 \\
\mathrm{Pu}-238 \\
\mathrm{Pu}-239 \\
\mathrm{Am}-241\end{array}$ & $\begin{array}{l}3 \times 10^{-8} \\
3 \times 10^{-10} \\
3 \times 10^{-10} \\
3 \times 10^{-10}\end{array}$ \\
\hline
\end{tabular}


Table B-2. RESP air, water, and soils samples for gamma spectrometry.

\begin{tabular}{|c|c|c|c|c|c|c|c|c|}
\hline \multirow[b]{2}{*}{ Radionuclides } & \multicolumn{2}{|c|}{ Air Filters } & \multicolumn{2}{|c|}{ Water Filtrate } & \multicolumn{2}{|c|}{ Water Insoluble } & \multicolumn{2}{|c|}{ Soils } \\
\hline & $\begin{array}{c}10^{-9} \\
\mathrm{pCi} / \mathrm{mL}\end{array}$ & $\begin{array}{l}\text { Total } \\
\mathrm{pCi}\end{array}$ & $\begin{array}{c}10^{-2} \\
\mathrm{pCi} / \mathrm{mL}\end{array}$ & $\begin{array}{c}\text { Total } \\
\mathrm{pCi}\end{array}$ & $\begin{array}{c}10^{-4} \\
\mathrm{pCi} / \mathrm{mL}\end{array}$ & $\begin{array}{c}\text { Total } \\
\mathrm{pCi}\end{array}$ & $\mathrm{pCi} / \mathrm{g}$ & $\begin{array}{r}\text { Total } \\
\mathrm{pCi}\end{array}$ \\
\hline Sc-46 & 1 & 6 & 0.2 & 8 & 5 & 2 & 0.19 & 120 \\
\hline $\mathrm{Cr}-51$ & 5 & 30 & 1.1 & 44 & 20 & 8 & 0.5 & 300 \\
\hline$M n-54$ & 0.5 & 3 & 0.5 & 20 & 3 & 1.2 & 0.1 & 60 \\
\hline $\mathrm{Co}-58$ & 0.5 & 3 & 0.09 & 3.6 & 4 & 1.6 & 0.1 & 60 \\
\hline $\mathrm{Fe}-59$ & 0.9 & 5.4 & 1.5 & 60 & 7 & 2.8 & 0.11 & 60 \\
\hline $\mathrm{Co}-60$ & 0.8 & 4.8 & 0.8 & 32 & 6 & 2.4 & 0.2 & 120 \\
\hline $\mathrm{Zn}-65$ & 1 & 6 & 0.5 & 20 & 15 & 6 & 0.2 & 120 \\
\hline $\mathrm{Nb}-94$ & 0.5 & 3 & 0.15 & 6 & 4 & 1.6 & 0.1 & 0.6 \\
\hline $\mathrm{Nb}-95$ & 0.5 & 3 & 0.11 & 4.4 & 80 & 32 & 0.1 & 0.6 \\
\hline $\mathrm{Zr}-95$ & 0.8 & 4.8 & 0.3 & 8 & 7 & 2.8 & 0.11 & 0.6 \\
\hline$R u-103$ & 0.7 & 4.2 & 0.16 & 6.4 & 4 & 1.6 & 0.1 & 0.6 \\
\hline$R u-106$ & 5 & 30 & 0.12 & 4.8 & 40 & 1.6 & 0.5 & 300 \\
\hline $\mathrm{Ag}-110 \mathrm{~m}$ & 0.5 & 3 & 0.15 & 6 & 5 & 20 & 0.1 & 60 \\
\hline $\mathrm{Sb}-124$ & 0.5 & 3 & 0.13 & 5.2 & 5 & 2 & 0.1 & 60 \\
\hline $\mathrm{Sb}-125$ & 1.5 & 9 & 0.3 & 12 & 15 & 6 & 0.2 & 120 \\
\hline Cs-134 & 0.6 & 3.6 & 0.09 & 3.6 & 4 & 1.6 & 0.1 & 60 \\
\hline Cs -137 & 0.8 & 4.8 & 0.3 & 12 & 20 & 8 & 0.1 & 60 \\
\hline $\mathrm{Ce}-141$ & 0.9 & 5.4 & 0.3 & 12 & 6 & 2.4 & 0.1 & 60 \\
\hline $\mathrm{Ce}-144$ & 5 & 30 & 1.0 & 40 & 20 & 8 & 0.4 & 240 \\
\hline $\mathrm{Eu}-152$ & 2 & 12 & 0.5 & 20 & 15 & 6 & 0.2 & 120 \\
\hline $\mathrm{Eu}-154$ & 2 & 12 & 0.3 & 12 & 15 & 6 & 0.3 & 180 \\
\hline $\mathrm{Eu}-155$ & 2 & 12 & 0.8 & 32 & 10 & 4 & 0.3 & 180 \\
\hline $\mathrm{Hf}-181$ & 0.6 & 3.6 & 0.12 & 4.8 & 6 & 2.4 & 0.1 & 60 \\
\hline $\mathrm{Ta}-182$ & 0.9 & 12 & 0.5 & 20 & 20 & 8 & 0.4 & 240 \\
\hline $\mathrm{Hg}-203$ & 0.5 & 3 & 0.15 & 6 & 2 & 0.8 & 0.1 & 60 \\
\hline$A m-241$ & 4 & 24 & 1.5 & 60 & 40 & 16 & 1.2 & 700 \\
\hline Gross Beta & 9.5 & & & & & & & \\
\hline Gross Alpha & 3.3 & & & & & & & \\
\hline
\end{tabular}


Table B-3. RESP biotic samples for gamma spectrometry.

\begin{tabular}{|c|c|c|c|c|}
\hline \multirow[b]{2}{*}{ Radionuclides } & \multicolumn{2}{|c|}{ Small Mammals } & \multicolumn{2}{|c|}{ Vegetation } \\
\hline & $\mathrm{pCi} / \mathrm{g}$ & $\begin{array}{l}\text { Total } \\
\text { pCi }\end{array}$ & $\mathrm{pCi} / \mathrm{g}$ & $\begin{array}{l}\text { Total } \\
\mathrm{pCi}\end{array}$ \\
\hline $\mathrm{Sc}-46$ & 0.2 & 12 & 0.07 & 12 \\
\hline $\mathrm{Cr}-51$ & 1.4 & 84 & 0.4 & 67 \\
\hline$M n-54$ & 0.18 & 11 & 0.05 & 8.4 \\
\hline Co-58 & 0.3 & 18 & 0.05 & 8.4 \\
\hline $\mathrm{Fe}-59$ & 0.6 & 36 & 0.08 & 14 \\
\hline $\mathrm{Co}-60$ & 1 & 60 & 0.1 & 17 \\
\hline $\mathrm{Zn}-65$ & 0.7 & 42 & 0.13 & 22 \\
\hline $\mathrm{Nb}-94$ & 0.2 & 12 & 0.05 & 8.4 \\
\hline $\mathrm{Nb}-95$ & 0.2 & 12 & 0.04 & 6.7 \\
\hline $\mathrm{Zr}-95$ & 0.3 & 18 & 0.07 & 8.4 \\
\hline$R u-103$ & 0.2 & 120 & 0.04 & 6.7 \\
\hline$R u-106$ & 2 & 12 & 0.5 & 8.4 \\
\hline $\mathrm{Ag}-110 \mathrm{~m}$ & 0.2 & 12 & 0.05 & 8.4 \\
\hline $\mathrm{Sb}-124$ & 0.2 & 12 & 0.04 & 6.7 \\
\hline $\mathrm{Sb}-125$ & 0.7 & 42 & 0.11 & 18 \\
\hline Cs-134 & 0.3 & 18 & 0.04 & 6.7 \\
\hline $\mathrm{Cs}-137$ & 1.3 & 78 & 0.13 & 22 \\
\hline $\mathrm{Ce}-141$ & 0.2 & 12 & 0.05 & 8.4 \\
\hline $\mathrm{Ce}-144$ & 1.1 & 66 & 0.16 & 27 \\
\hline$E u-152$ & 0.6 & 36 & 0.1 & 17 \\
\hline Eu-154 & 0.7 & 42 & 0.15 & 25 \\
\hline $\mathrm{Eu}-155$ & 0.6 & 36 & 0.1 & 17 \\
\hline $\mathrm{Hf}-181$ & 0.2 & 12 & 0.04 & 6.7 \\
\hline $\mathrm{Ta}-182$ & 1.1 & 66 & 0.3 & 50 \\
\hline $\mathrm{Hg}-203$ & 0.16 & 96 & 0.05 & 8.4 \\
\hline$A m-241$ & 2 & 120 & 0.3 & 50 \\
\hline
\end{tabular}


distinguish clearly the true result being obtained from results that are vastly different because of poor statistics. This precision requires from 500 to 2500 counts under the conditions described, or about 1 to $6 \mathrm{pCi}$ per sample. The precision of measuring the higher level of activity is not affected significantly by small activities of contamination in tracers and blanks. Therefore, it is incorrect to define the higher level in terms of multiples of the stated detection limit.

Two levels of activity are necessary to check both the stated detection limits and to determine the accuracy and precision with which larger activities can be measured. The lower level consists of activities from about 1.5 to 5 times the stated absolute detection limit to maximize the influence of backgrounds, blanks, and incomplete separation of interferences from the sample on the net activity being measured. No attempt is made to verify stated detection limits by analysis of blank samples. This is due to the statistical uncertainty of a net result obtained by subtracting a reagent blank from a sample that is also blank. Also, several different types of problems can give a blank result even when considerable activity is present. For example, there could be a complete loss of the radionuclide being determined in the absence of a tracer, complete exchange, or sample dissolution, or failure to turn up the high voltage to the detector or power up the instrument. The higher level consists of activities sufficiently high to distinguish clearly the true result being obtained from results that are vastly different because of poor statistics. This precision requires from 500 to 2500 counts under the conditions described, or about 1 to $6 \mathrm{pCi}$ per sample. The precision of measuring the higher level of activity is not affected significantly by small activities of contamination in tracers and blanks. Therefore, it is incorrect to define the higher level in terms of multiples of the stated detection limit.

In barren rocks, water, air dusts, blanks, etc., the detection limits for U-238, U-235, and U-234 are essentially the same as those quoted above for other alpha-emitting nuclides. However, the entire crust of the earth contains about 2.5 $\times 10^{-4} \%$ natural uranium, which is equivalent to about $1 \mathrm{pCi} / \mathrm{g}$ each of $U-238$ and $\mathrm{J}-234$ and about $5 \mathrm{E}-2 \mathrm{pCi} / \mathrm{g}$ of $\mathrm{U}-235$. This is 333 times the ideal detection limit for a $10 \mathrm{~g}$ sample of soil and would render both $U-238$ and U-234 detectable in air durts, water smears, etc., containing more than $30 \mathrm{mg}$ of average soil. Consequently, analytical detection limits are meaningless for such types of samples already containing uranium naturally. In addition, the natural level of uranium can vary by a factor of 5- to 10-fold from the average, either up or down, so that levels of at least 5 to $10 \mathrm{pCi} / \mathrm{g}$ would be required to give some confidence that uranium had been detected above the natural levels. An almost catastrophic accident would be required in order for this much uranium to be released over any significant area from a burial site, processing plant, etc. Also, low-grade uranium ores containing 100 times the average are common, such as phosphate rock used in the manufacture of elemental phosphorous. The practical detection limit for air dusts, vegetation, animal tissues, water, etc., depends on how much soil is present in the samples. Isotopic ratios of $U-238$ to $U-234$ would be of some assistance but both enriched (in U-234) and depleted uranium occur commonly in nature. 


\section{GAMMA SPECTROMETRIC ANALYSIS DETECTION LIMITS}

Tables B-2 and B-3 give absolute detection limits in the right-hand column for each sample type. The absolute detection limits are the total activities that should be present in the sample aliquot taken for analysis to be detected under the counting conditions described and calculated according to the definition of L. A. Currie. This definition is: detection limit $=\left(2.71+4.66 \mathrm{~B}^{1 / 2}\right) /(\mathrm{t} \mathrm{x}$ $E \times P \times 2.22)$ where " $B$ " is the total correction in counts (Compton, background, blanks, etc., for the same counting time), " $t$ " is the counting time in minutes, " $E$ " is the counting efficiency as a fraction, "P" is the gamma-ray emission probability for the particular gamma ray being measured, and 2.22 is the $\mathrm{dpm} / \mathrm{pCi}$.

The figures in the left-hand column of each sample type give the same detection limits expressed in terms of $\mathrm{pCi} /$ unit weight or volume for the average sample sizes expected to be analyzed. Because the absolute detection limits must remain constant for a given counting time and efficiency, the detection iimits in terms of concentrations become higher or lower as the sample size actually used in the analysis becomes smaller or larger. Shown in Table B-4 are descriptions of environmental monitoring samples for gamma spectrometry analysis and counting conditions for stated detection limits.

Quality assurance samples are prepared as nearly identically to the real samples as possible. Air samples are simulated by spotting known quantities of activity as uniformly as possible over the filters and drying. Water solutions will contain known quantities of water-soluble tracers in dilute nitric acid. For soils, approximately $700 \mathrm{~g}$ of barren soil are spiked with soil standards containing exact known quantities of the radionuclides of interest homogeneously distributed throughout the sample. For dried vegetation and animal tissue, vegetation (avg wt $100 \mathrm{~g}$ ), mice (avg wt $55 \mathrm{~g}$ ) and ground squirrels (avg wt $85 \mathrm{~g}$ ) are spiked as homogeneously as possible with exactly known quantities of tracer solutions evaporated to dryness on about $100 \mathrm{mg}$ of clean, dry minus 100 -mesh soil to enable quantitative transfer to the samples without wetting.

Two levels of activity are necessary to check both the stated detection limits and to determine the accuracy and precision with which larger activities can be measured. The lower level consists of activities from about 1.5 to 5 times the stated absolute detection limits to maximize the influence of backgrounds, blanks, and interferences from the sample on the net activity being measured. Specifically, no attempt is made to verify stated detection limits by analysis of blanks due to the large statistical uncertainties of net results obtained from subtracting blanks from samples that are also blank. The higher level consists of sufficient activity to permit relative standard deviations of 1 to $5 \%$ to minimize statistical uncertainties and make clearer the precision and accuracy being obtained. 
Table B-4. Description of environmental monitoring samples for gamma spectrometry analysis.

\begin{tabular}{|c|c|c|}
\hline Media & Sample Description & Conditions of Counting \\
\hline Air & $\begin{array}{l}\text { Sampled at approximately } 4 \mathrm{cfm} \text { for } \\
2 \text { weeks on } 4 \text {-in. Versapor } 1200 \\
\text { membrane filters for a total of } 3 \times 10^{9} \\
\text { cc per filter. }\end{array}$ & $\begin{array}{l}\text { Monthly composite samples of two } 4 \text { in. } \\
\text { filters containing a total of about } 6 \times 10^{9} \mathrm{cc} \\
\text { of air are held flat over the detector and } \\
\text { counted for } 12 \text { to } 16 \text { hours dependency on } \\
\text { the detector system used. }\end{array}$ \\
\hline Water & $\begin{array}{l}\text { 4- } \mathrm{L} \text { collapsible polyethylene con- } \\
\text { tainer containing } 25 \mathrm{~mL} \text { of conc. } \\
\mathrm{HNO}_{3} \text { and two Whatman ashless fil- } \\
\text { ter paper tablets for } 4000 \mathrm{~mL} \text { of wa- } \\
\text { ter. }\end{array}$ & $\begin{array}{l}\text { The sample is shaken vigorously to dis- } \\
\text { lodge all material from the sides and bot- } \\
\text { tom of the container and filter. The filtrate } \\
\text { is transferred to a } 4-\mathrm{L} \text { Marinelli beaker } \\
\text { and counted for } 16 \text { hours. The filter and } \\
\text { paper pulp are also counted for } 16 \text { hours in } \\
\text { contact with detector. Sample size, } \\
4000 \mathrm{~mL} \text {. }\end{array}$ \\
\hline Soil & $\begin{array}{l}16-0 z \text { squat jar filled to the bead } \\
\text { below the threads after settling. }\end{array}$ & $\begin{array}{l}\text { The sample is counted in the squat jar for } \\
2 \text { hours with the jar being rotated as close } \\
\text { to the detector as possible. Sample size ap- } \\
\text { proximately } 700 \mathrm{~g} \text {. }\end{array}$ \\
\hline Vegetation & $\begin{array}{l}16-0 z \text { squat jar filled to the bead } \\
\text { below the threads after settling. }\end{array}$ & $\begin{array}{l}\text { The dry sample is counted in the squat jar } \\
\text { for } 16 \text { hours with the jar being rotated as } \\
\text { close to the detector as possible. Sample } \\
\text { size about } 150 \mathrm{~g} \text {, average. }\end{array}$ \\
\hline
\end{tabular}




\section{Appendix C}

\section{Statistical Analysis Methods}




$$
\text { C-2 }
$$




\section{Appendix C}

\section{Statistical Analysis Methods}

\section{GENERAL}

Statistical considerations are important in sampling program design, whether for large or small sampling efforts, and all sampling data must be interpreted in light of the inherent statistical nature of the sampling and analytical processes. This appendix summarizes the statistical methods used in the analysis of EM data. These methods are detailed in Blackwood ${ }^{\mathrm{C}-1}$ and are designed to be consistent with EM program data quality objectives (DQOs).

\section{DATA PRETREATMENT AND VALIDATION}

Prior to using data for comparative purposes, data are prescreened to ensure no gross data errors occur, such as transcription errors, needlessly missing values, data points out of range, and data points that do not meet other specific criteria. Initial screening includes eliminating data from instruments not meeting minimum required operating characteristics as specified in the DQOs. DQOs state that laboratory analytical uncertainties on each measurement must have a coefficient of variation (CV) of $\leq 33 \%$ if data are to be used to report a quantitative result for comparison to action levels for the various monitoring activities. A CV of between $33 \%$ and $50 \%$ is required for use in trend analysis. A CV greater than $50 \%$ is taken to indicate a' measurement is indistinguishable from zero. For individual measurements, these are suitable guidelines. For measurements combined for calculating means and/or trends, these restrictions are unnecessary, as long as the uncertainties are taken into account in the analysis.

Once the basic checks for errors and operating criteria are complete, the data are screened for outliers. Graphical techniques (e.g. probability plots, stem and leaf plots, box plots, and other exploratory data analysis techniques) are the primary tools used for detecting potential data outliers. In cases where outliers are traceable to a specific error, a corrected value may be used to replace the outlier. If no correction is possible, then the point is deleted from the data set. Rarely are outliers with unattributable causes eliminated from the data set. Such outliers may be truly accurate data measurements indicative of unusual but important phenomena. In these cases, two sets of analyses are performed with the outlier(s), one with and one without providing results that can be compared.

\section{DISTRIBUTIONAL ANALYSIS}

Most of the preferred methods for uncertainty interval calculation and other analyses of data using classical statistical methods assume a normal distribution for the data. The power and versatility of these techniques makes their use preferable, if the normality assumption can be met. If the data are not normally distributed, but a mathematical transformation of the data produces values that are normally distributed, then the same techniques can be applied to the transformed data. If no suitable transformation can be found, the usual alternative is to use nonparametric analysis (although parametric techniques for non-normally distributed data are sometimes available). Nonparametric techniques are generally not as powerful as parametric techniques performed on normally distributed data, but are often more powerful than normal based techniques used on non-normal data. Given these considerations, an important first step in the detailed analysis of each type of monitoring data i $t o$ attempt to determine the proper distribution for the data.

Two aspects of distributions of measurements are of interest. First is the distribution of sampling and/or measurement error associated with individual observations. This distribution is important in determining individual measure- 
ment confidence intervals. The second distribution is the distribution among multiple measurements over time at a specific location. This distribution is required for trend analysis and comparisons among measurements. As described below, the distribution across measurements is affected by the distribution of the sampling and/or measurement error.

Distributional tests are always based on at least ten measurements. Data from several recent years are sometimes combined to provide more power in the distributional tests. The number of points from the past to use depends in part on whether there are trends in the data. Data can be used without problem for as far back in time as there appear to be no significant trends. If there are obvious trends in the data, the distributional tests are performed on detrended data (i.e. residuals after fitting models with trend effects). Adequate estimation of trends for the purpose of distributional analysis can be obtained using least squares methods of estimation, although the usual tests of significance for trends will be suspect unless the data are approximately normal. In examining the data for trends, both the raw data and $\log$ transformed data are sometimes plotted; trends may appear more readily in the log transformed data.

While tests on small sets of monitoring data may indicate an adequate fit of the normal distribution to data collected over time at a specific location, such results may be due to lack of power in the test. Other distributions may fit better, even when an adequate fit to a normal is indicated. Thus the focus in the distributional analysis is on comparing the fit of the untransformed data to a normal distribution to the fit obtained after various data transformations. The logarithmic transformation (resulting in the lognormal distribution if the transformed data are normally distributed) is the obvious first choice among transformations, but others may apply as well. A measurement model developed for monitoring data and analysis of previous years data for several of the monitoring activities indicates that better normal fits will often be obtained after some form of transformation. For example, analysis of
90-91 data for gross alpha and gross beta air monitor data indicate that the normality assumption is never valid, and that either a square root or logarithmic transformation applied to the data is best for achieving normality.

Basic distributional testing of the monitoring data consists of examining normal probability plots for at least the raw data, logarithmic transformed data, and square root transformed data. The Shapiro-Wilk test for normality is also performed for each of the three distributions to determine the best fitting distribution for the data. Other transformations may be considered as deemed necessary.

The coefficient of variation for the raw data is also sometimes used as an indicator of the type of distribution to expect. Positive valued data with a CV of greater than $50 \%$ are unlikely to be normal. Conversely, data sets with large numbers of negative values cannot be considered lognormally distributed or square root normal, since neither distribution allows negative values. The logarithmic or square root transformed data can be used if there are only a few negative values and the transformed positive values fit a normal distribution well. (In some cases it may make sense to substitute small positive values - such as $1 / 2$ the cietection limit-for the negative values to be able to include all the points in an analysis on the transformed data.)

\section{COMPARISON OF INDIVIDUAL MEASUREMENTS TO SPECIFIC LIMITS}

Most of the monitoring activities have as an objective the comparison of measured values to specific stated lirnits. These limits are generally derived concentration guides, regulatory standards, or action levels based on directives or standard operating procedures. (For simplicity, the discussion that follows uses the term action level generically to refer to all three types of limits.)

Comparisons to action levels are distinguished from comparisons to other measured values because the action levels are fixed quantities, 
without error. (Comparing two measured values involves error in both values). Comparing individual values to action levels is achieved by calculating a $95 \%$ confidence interval for the measurement and comparing it to the action level. If the action level for that measurement is greater than the upper bound of the confidence interval, then we can conclude with $95 \%$ confidence that the measured value is significantly lower than the action level. Since the concern is always whether or not the observed level exceeds the corresponding limit, a one sided confidence interval is used.

In calculating confidence intervals, two issues are of concern, estimating the size of the errors in the sampling and/or measurement process and the distribution of those errors. Analytical or measurement error alone (the value reported by the analysis laboratory) should rarely be used to infer a confidence interval for any of the monitoring measurements. Analytical error is only one component of the overall error. The other major component is sampling error which includes variability due to sample preparation, sample variability (e.g. due to extracting only a portion of an air filter for analysis), sample handling, sample processing etc. Analytical error is in fact often the smallest component of the overall measurement error.

Sampling and measurement error estimates are based on replicate data whenever possible. For example, for gross alpha and gross beta air monitor measurements, replicates are available by using the paired data for locations at which two samplers have been located. Replicate data for penetrating radiation monitoring is obtainable from the five thermoluminescent dosimeter chips placed at each measurement location.

\section{TREND ANALYSIS}

\section{Short Term Trends or Changes}

The DQOs for the various monitoring activi- ties generally refer to evaluation of trends in relation to background levels. Background levels may be location specific (i.e. the background locations at RWMC and WERF) or general (i.e. RESLs background locations). Comparing current measurement values at each location to the value for the previous recording period is a form of trend analysis (perhaps more appropriately called change analysis), suitable for looking for abrupt changes during the year.

Statistical comparison of current measurement values to previous values at a specific location is obtained using sampling and/or measurement error variance estimates (as described in Blackwood, ${ }^{\mathrm{C}-1}$ ) and an estimate of the covariance of sequential measurements. (It is assumed here that the data exhibit positive autocorrelation. That is, current and previous measurement values at a specific location are positively correlated). Formulas for calculating autocovariance and tests of significance for sequential measurements are given in Blackwood. ${ }^{\mathrm{C}-1}$

\section{Long Term Trends}

General evaluation of long term trends is primarily achieved graphically, by plotting values for specific locations and for appropriate background locations on the same graph. Even when the data test to be different from lognormal, longer term trends will be most influenced by the lognormal characteristics of the true values (e.g., changes will more likely be multiplicative rather than additive in nature); therefore, the trend data is plotted using a logarithmic measurement axis. Since the focus is on comparative changes relative to background, another graphical alternative is to calculate the differences (or ratios in the case of lognormal data) between location measurements and background. These values will be detrended with regard to cyclical and other variations affecting background and site locations equally, so that any observable trend will be immediately attributable to a change in the site location relative to the background location. 


\section{C-6}




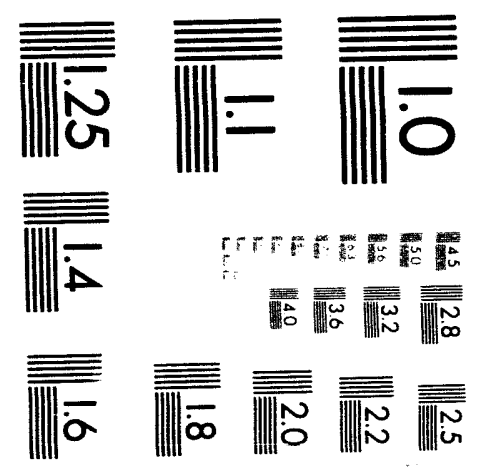



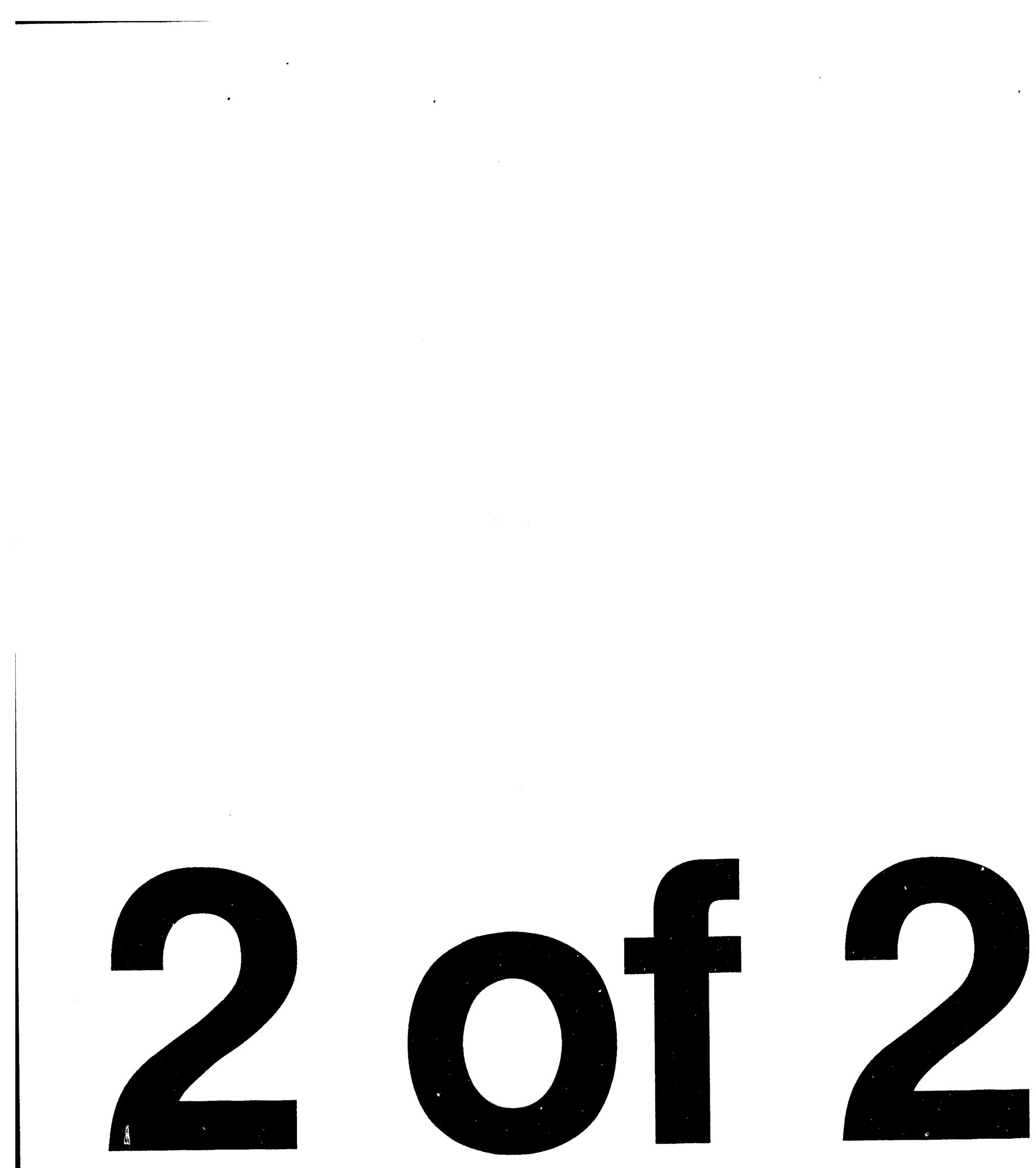


\section{REFERENCES}

C-1. Blackwood, L. G., Statistical Analysis Methods for Data From the EG\&G Idaho Environmental Unit Radiological Environmental Surveillance Program, EG\&G Idaho, Inc., EGCRAAM-10785, 1993. 


\section{Appendix D \\ Environmental Standards}

D-1 


$$
\text { D-2 }
$$




\section{Appendix D}

\section{Environmental Standards}

\section{RADIOLOGICAL MONITORING AT WASTE MANAGEMENT FACILITIES}

Radionuclide concentrations in air and subsurface water samples collected at the RWMC, the WERF, and the MWSF are compared with DCG values for air and water. ${ }^{\mathrm{D}-1}$ The DCG values listed are provided as reference values for conducting radiological protection programs at operational DOE facilities and sites. The DCG values for internal exposure are based on a committed effective dose equivalent (EDE) of 100 mrem for the radionuclide taken into the body by ingestion or inhalation during one year. Radionuclide concentrations in soil samples are compared to environmental concentration guidelines for soils, based on an on-Site "homesteader."

Table D-1 lists applicable DCGs. The DCGs represent the concentrations of radioactivity in air inhaled or water ingested continuously during a year that resulted in a 100-mrem, 50-year committed EDE. The DCGs are used as a point of reference only. Comparison of individual measurements to the DCGs gives the maximum dose a person could receive at the location where the sample was collected, given the following two assumptions: (1) that the concentration was at the DCG level continuously for the entire year, and (2) the person receiving the exposure was at that location for the entire year, continually drinking the water or inhaling the air. In practice, DCGs are rarely, if ever, exceeded for even a short period during the year. In addition, the radionuclide concentration at any area accessible to the public will be even less due to the dispersion from the facility boundary (where the sample was taken) to the site boundary (the closest location where the public has unrestricted access).

Table D-2 lists environmental concentration guidelines for the radionuclides in scil that are most likely to be found in environmental samples collected at the RWMC. The concentration guides in Table D-2 are based on a homestead scenario. This scenario considers the radiation dose to the homesteader from inhalation and ingestion of radionuclides, as well as external radiation. Since the hypothetical homesteader is living on the contaminated area, this scenario results in very conservative concentration guides. The homestead scenario provides overestimates of the actual doses that would be received by off-homestead individuals from waste radionuclides in soil at the RWMC. 
Table D-1. Derived concentration guides (DCGs).

\begin{tabular}{|c|c|c|}
\hline \multirow[b]{2}{*}{ Radionuclide } & \multicolumn{2}{|c|}{ DCGs for the Public ${ }^{a, b}$} \\
\hline & $\begin{array}{l}\text { DCG for Air } \\
(\mu \mathrm{Ci} / \mathrm{mL})\end{array}$ & $\begin{array}{l}\text { DCG for Water } \\
(\mu \mathrm{Ci} / \mathrm{mL})\end{array}$ \\
\hline $\mathrm{H}-3$ & $1 \times 10^{-7}$ & $2 \times 10^{-3}$ \\
\hline $\mathrm{Sc}-46$ & $6 \times 10^{-10}$ & $2 \times 10^{-5}$ \\
\hline $\mathrm{Cr}-51$ & $5 \times 10^{-8}$ & $1 \times 10^{-3}$ \\
\hline $\mathrm{Mn}-54$ & $2 \times 10^{-9}$ & $5 \times 10^{-5}$ \\
\hline $\mathrm{Co}-58$ & $2 \times 10^{-9}$ & $4 \times 10^{-5}$ \\
\hline $\mathrm{Fe}-59$ & $8 \times 10^{-10}$ & $2 \times 10^{-5}$ \\
\hline $\mathrm{Co}-60$ & $8 \times 10^{-11}$ & $5 \times 10^{-6}$ \\
\hline $\mathrm{Zn}-65$ & $6 \times 10^{-10}$ & $9 \times 10^{-6}$ \\
\hline $\mathrm{Sr}-90$ & $9 \times 10^{-12}$ & $1 \times 10^{-6}$ \\
\hline $\mathrm{Nb}-95$ & $3 \times 10^{-9}$ & $6 \times 10^{-5}$ \\
\hline $\mathrm{Zr}-95$ & $6 \times 10^{-10}$ & $4 \times 10^{-5}$ \\
\hline$R u-103$ & $2 \times 10^{-9}$ & $5 \times 10^{-5}$ \\
\hline $\mathrm{Ru}-106$ & $3 \times 10^{-11}$ & $6 \times 10^{-6}$ \\
\hline $\mathrm{Ag}-110 \mathrm{~m}$ & $2 \times 10^{-10}$ & $1 \times 10^{-5}$ \\
\hline $\mathrm{Sb}-125$ & $1 \times 10^{-9}$ & $5 \times 10^{-5}$ \\
\hline I-129 & $7 \times 10^{-11}$ & $5 \times 10^{-7}$ \\
\hline $\mathrm{I}-131$ & $4 \times 10^{-10}$ & $3 \times 10^{-6}$ \\
\hline $\mathrm{Cs}-134$ & $2 \times 10^{-10}$ & $2 \times 10^{-6}$ \\
\hline Cs-137 & $4 \times 10^{-10}$ & $3 \times 10^{-6}$ \\
\hline $\mathrm{Ce}-141$ & $1 \times 10^{-9}$ & $5 \times 10^{-5}$ \\
\hline $\mathrm{Ce}-144$ & $3 \times 10^{-11}$ & $7 \times 10^{-6}$ \\
\hline $\mathrm{Eu}-152$ & $5 \times 10^{-11}$ & $2 \times 10^{-5}$ \\
\hline $\mathrm{Eu}-154$ & $5 \times 10^{-11}$ & $2 \times 10^{-5}$ \\
\hline $\mathrm{Ra}-226$ & $1 \times 10^{-12}$ & $1 \times 10^{-7}$ \\
\hline $\mathrm{Pu}-238$ & $3 \times 10^{-14}$ & $4 \times 10^{-8}$ \\
\hline $\mathrm{Pu}-239^{\mathrm{c}}$ & $2 \times 10^{-14}$ & $3 \times 10^{-8}$ \\
\hline Am-241 & $2 \times 10^{-14}$ & $3 \times 10^{-8}$ \\
\hline $\mathrm{U}-235$ & $1 \times 10^{-13}$ & $6 \times 10^{-7}$ \\
\hline $\mathrm{U}-238$ & $1 \times 10^{-13}$ & $6 \times 10^{-7}$ \\
\hline Gross Alpha ${ }^{c}$ & $2 \times 10^{-14}$ & \\
\hline Gross Beta ${ }^{c}$ & $9 \times 10^{-12}$ & \\
\hline
\end{tabular}

a. This table contains the air and water DCGs based on concentrations that could be continuously inhaled or ingested, respectively, and do not exceed an effective dose equivalent of $100 \mathrm{mR} / \mathrm{yr}$.

b. DCGs apply to radionuclide concentrations in excess of those occurring naturally or due to fallout.

c. The DCGs of Pu-239 and Sr-90 are the most restrictive for alpha- and beta-emitting nuclides, respectively, and are appropriate to use for gross alpha and gross beta DCGs. 
Table D-2. Environmental concentration guidelines for radionuclides in soil that are most likely to be found in environmental samples collected at the RWMC.

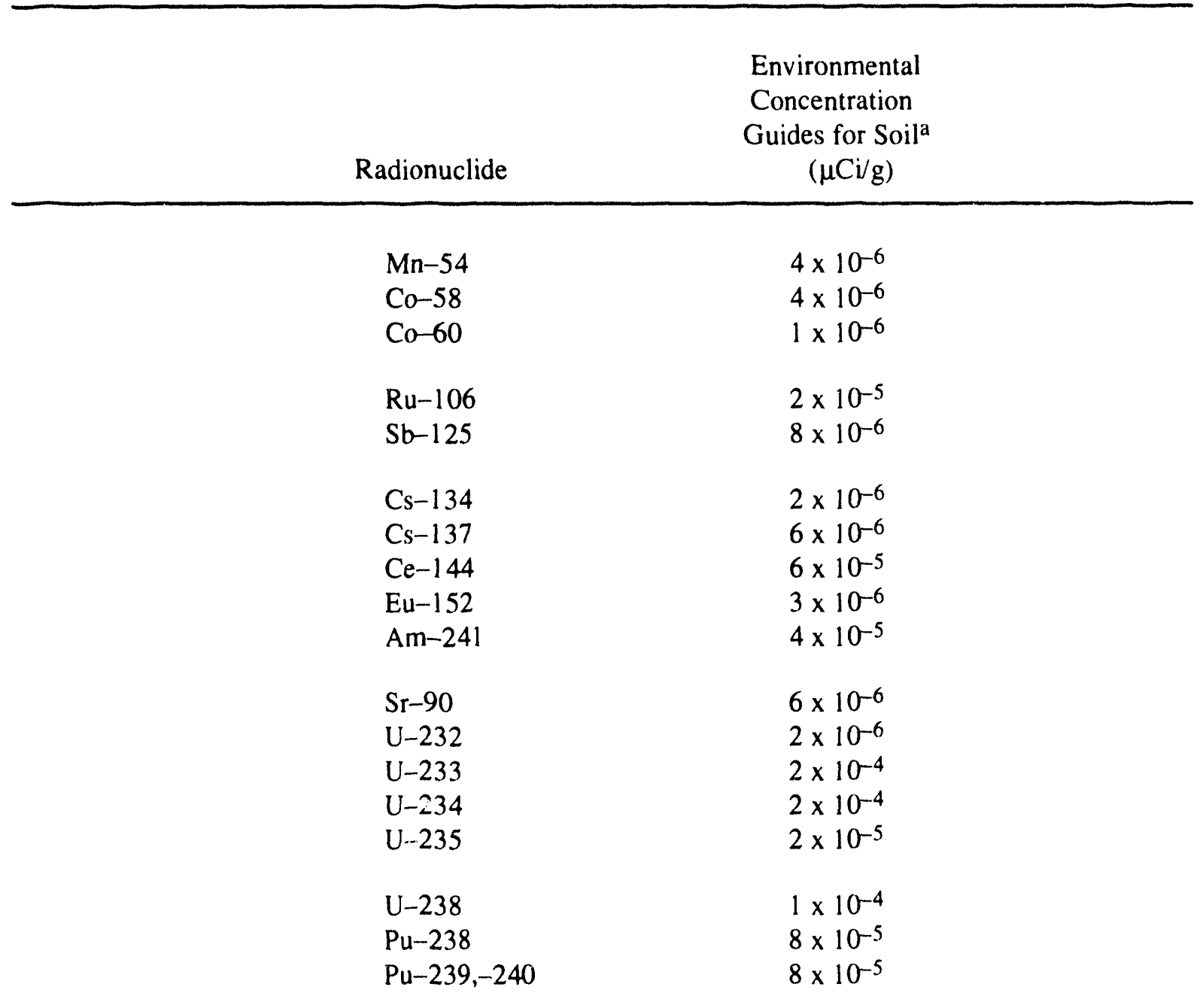

a. See Reference D-2. Concentrations correspond to a 50-yr dose commitment of $100 \mathrm{mrem} / \mathrm{yr}$ to a homesteader beginning in the first year after release of facility. This concentration assumes uniform contamination of an area adequate for subsistence farming. 


\section{SUBSURFACE WATER}

The environmental regulations that apply to the drinking water monitoring program are as follows: the Federal Safe Drinking Water Act, Code of Federal Regulations (40 CFR Parts 141-143); the Idaho Regulations for Public Drinking Water Systems, IDAPA 16.01.08000-.08999; ${ }^{\mathrm{D}-3}$ DOE Order 5400.5, Part D; and Environmental Compliance Planning Manual (see Table D-3).

In addition to the eighteen regulated VOCs, unregulated organic compounds are monitored and reported.

The INEL is a nuclear facility, which implies that radiological contamination of the drinking water is a possibility. Because of the possibility of radiological contaminants, EG\&G Idaho monitors for gross aipha/beta and tritium (see Table D-4) as recommended in the Idaho Regulations for Public Drinking Water Systems (IDAPA 16.01.08100,06). 
Table D-3. Standards for volatile organic compounds.

\section{REGULATED VOCs}

Parameter

Benzene

Vinyl Chloride

Carbon Tetrachloride

1,2-Dichloroethane

Trichloroethylene

1,1-Dichloroethylene

1,1,1-Trichloroethane

para-Dichlorobenzene

cis-1,2-Dichloroethylene

1,2-Dichlorpropane

Ethylbenzene

Monochlorobenzene

O-Dichlorobenzene

Styrene

Tetrachloroethylene

Toluene

Trans-1,2-Dichloroethylene

Xylenes (total)
Maximum Contaminant Level $(\mathrm{mg} / \mathrm{L})$

0.005

0.002

0.005

0.005

0.005

0.007

0.200

0.075

0.07

0.005

0.7

0.1

0.6

0.1

0.005

1.0

0.1

10.0 
Table D-3. (continued).

\section{UNREGULATED VOCs WITH NO MCL}

Chloroform

Bromodichloromethane

Chlorodibromomethane

Bromoform

M-Dichloromethane

Dichloromethane

Dibromomethane

1,1-Dichloropropane

1,1,1,2-Tetrachloroethane

Chloroethane

1,1,2-Trichloroethane

2,2-Dichloropropane

Bromomethane

1,2,3-Trichlorobenzene

N-Butylbenzene

Napthalene

Hexachlorobutadiene

1,3,5-Trimethylbenzene

P-isopropylbenzene
O-Chlorotoluene

P-Chlorotoluene

Bromobenzene

1,3-Dichloropropene

Ethylene Dibromide (EDB)

1,2-Dibromo-3-Chloropropane (DBCP)

1,2,4-Trimethylbenzene

1,2,4-Trichlorobenzene

1,1-Dichloroethane

1,1,2,2-Tetrachloroethane

1,3-Dichloropropane

Chloromethane

Isopropylbenzene

Tert-Butylbenzene

SEC-Butylbenzene

Fluorotrichloromethane

Dichlorodifluoromethane

Bromochloromethane

1,2,3-Trichloropropane 
Table D-4. Applicable radiological drinking waters standards.

Maximum Contaminant Level

Parameter (pCi/L)

Gross Alpha

15

Gross Beta

50

Tritium

20,000 
D-10

$-$ 


\section{REFERENCES}

D-1. Department of Energy, "Radiation Protection of the Public and the Environment," DOE Order 5400.5, February 8, 1990.

D-2. EG\&G Idaho, Inc., Development of Criteria for Release of Idaho National Engineering Laboratory Sites Following Decontamination and Decommissioning, EGG-2400, August 1986.

D-3. Idaho Regulations for Public Drinking Water Systems, IDAPA 16.01.08000-08999, December 5, 1992 

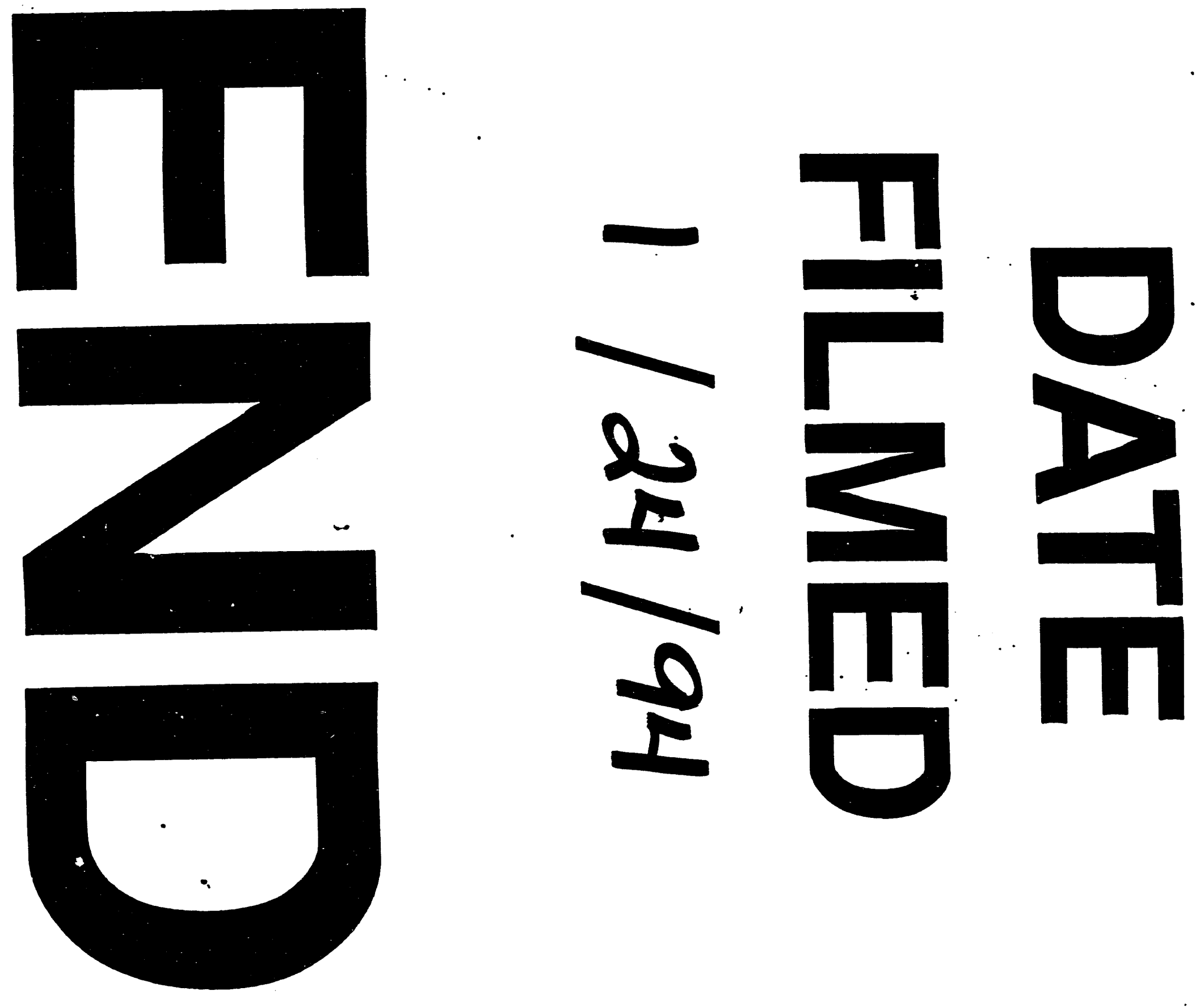
